\title{
Uptown East; \\ Proposal for the redevelopment of Manor Park Ottawa
}

by

\author{
Angella Hercules Stevenson
}

\author{
A thesis submitted to the Faculty of Graduate and Postdoctoral Affairs \\ in partial fulfillment of the requirements for the degree of \\ Master of Architecture Professional \\ Carleton University \\ Ottawa, Ontario
}

(C) 2013

Angella Hercules Stevenson 


\section{Abstract}

This thesis examines challenges and opportunities associated with the intensification of established suburban neighbourhoods, questioning how the forces acting on them might be leveraged to create higher-performing communities without compromising the existing social or architectural character.

Drawing on a of review of literature and an analysis of precedents, the design portion of this thesis uses Ottawa's Manor Park neighbourhood as a hypothetical case study to explore how intensification might enrich suburban areas. Among other things, the demonstration plan for Manor Park illustrates how Clarence Perry's neighbourhood unit diagram continues to be relevant. Implicit in this unit, which was the basic module for many suburban communities, is a roadmap for accommodating environmentally sustainable intensification without threatening existing neighbourhood character or cohesion.

While the approaches explored in the demonstration plan are specific to Manor Park, they can be easily adapted to similar suburban neighbourhoods across North America. 


\section{Acknowledgements}

I would like to express my sincere gratitude to my advisor Prof. Ben Gianni whose knowledge, and guidance has been pivotal to the development of this thesis.

I would also like to thank my family for supporting me in every way through my university education. In particular, I would like to thank my husband, Jogger Hercules, who has patiently and lovingly supported and encouraged the pursuit of my dreams. A special thank you goes out to Aunt Donna for her editing help. 


\section{Contents}

Uptown East;

Abstract

Acknowledgements

3

Contents

4

Introduction

5

Chapter 1

Background

Chapter 2

26

Manor Park

Chapter 3

39

Sustainability

Chapter 4

50

Demonstration Plan

Chapter 5

84

Post-Script

Appendices

88

List of Illustrations

Bibliography

94 


\section{Introduction}

The shape of North American cities was strongly influenced by the wave of automobile suburbs that appeared in the post-war decades. Indeed, roughly $80 \%$ of all housing in North America was built after WWII, most of it having been constructed by what are known as "merchant builders" following strategies established during World War Two (WWII). ${ }^{1}$ Many of these suburban communities are or will soon be under pressure to intensify as municipalities attempt to curb sprawl and optimize the use of existing infrastructure. Ottawa's Manor Park, one of the first residential subdivisions to appear in post-war Canada, is one such neighbourhood. This thesis explores the challenges and opportunities associated with the intensification of established suburban neighbourhoods like Manor Park. The intention is to explore ways in which the forces acting on neighbourhoods might be channelled to create higher-performing communities while enhancing the existing social stability and architectural character.

In cities where the population is expected to grow, intensification of existing neighbourhoods is inevitable - especially relatively low-density neighbourhoods adjacent to transit stops and/or close to the urban core. Driving the pressure to intensify are changes in household composition, the increasing cost of development on the periphery, and the targets set by many cities to curb sprawl and reduce investment in new infrastructure. As a result of sprawl, many suburban neighbourhoods that were constructed on the far periphery of cities, are now considered to be close to the core. In particular, those built in the late 1940s and the 1950s were constructed at densities that are now considered to be out of synch with evolving standards for "in-town" neighbourhoods.

The province of Ontario, and the City of Ottawa have each implemented policies to encourage intensification. The Ontario Provincial Policy statement requires, "Planning Authorities [to] identify and promote opportunities for intensification and redevelopment." ${ }^{2}$ Meanwhile, the City of Ottawa Official Plan focuses intensification on existing urban areas, while being sensitive to the compatibility of the design to the existing character. ${ }^{3}$ In discussing the compatibility of new development, Ottawa Official Plan notes "the more a new development can incorporate the common characteristics of its setting in its design, the more compatible it will be," ${ }^{4}$ while acknowledging "a development can be designed to fit and work well in a certain existing context without being 
'the same as' the existing development.."5

\section{Methodology}

This thesis divides into two parallel studies: one undertaken through writing and the other through design. The written portion includes a literature review organized under the broad headings of the history of post-war suburbanization, sustainable design, suburban intensification (through a review of precedents). The history of post-war suburbanization is important inasmuch as government policies, changes in building practices, and ideas about where and how to raise a family had a strong influence on the shape of the post-war city. Levittown (New York) and Don Mills (Toronto), celebrated post-war suburbs, are analysed to better understand the forces and principles behind suburban development, including the neighbourhood unit.

While less well known, Ottawa's Manor Park neighbourhood was conceived as a prototype for the post-war Canadian suburb. The history of Manor Park is important as the design portion of the thesis proposes a demonstration plan for the intensification of Manor Park Estates, a 22-acre campus of rental housing within the neighborhood. Among the issues at play is an understanding of how new development can integrate with and complement the existing community, whose form and character are strongly connected with its history.

Sustainable design is a key topic in the fields of architecture and urban design, and there is much that these disciplines can contribute to the discussion. As such, a review of literature about sustainability helps orient the reader and inform the decisions made in the design portion of the thesis. Several precedents for suburban intensification were examined to understand the application of principles to real situations.

The demonstration plan for the transformation of Manor Park is intended both to be specific and generic. While specific to the neighbourhood's character and status as a prototypical post-war suburb, it is my hope that the resulting recommendations and strategies could be applied to similar neighbourhoods under pressure to intensify.

As it has been undertaken in the context of a professional degree in Architecture (M.Arch.), the thesis understands design as form research - as important as other methods of critical exploration. Many of the conclusions drawn are empirical, based on an iterative process of design. Successive iterations were necessary to synthesize, interpret and evaluate the various data covered in the literature review, with the goal of finding an approach to intensification that adhered to current thinking about sustainability, was respectful of the existing character of the neighbourhood, and best served both existing and future residents.

Having observed how closely Manor Park corresponds to Clarence Perry's neighbourhood diagram, the thesis uses this diagram 
as a framework through which to explore how ideas about the structure of suburbs have transformed over the course of the $20^{\text {th }}$ century. In line with the City of Ottawa's Official Plan, the proposed intensification of Manor Park will emphasize the importance of enhancing the existing architectural and urban character of the neighbourhood. The exploration is motivated, in part, by an attempt to discover if redevelopment can enable an established neighbourhood to be more like it was originally intended to be.

Redevelopment provides the opportunity to re-visit, reinterpret, and possibly realize some of the initial goals for the community within the framework of the current market preferences and thinking about cities. The larger goal is to leverage development pressures and opportunities to produce better integrated, more socially, economically, and environmentally balanced communities without compromising the fundamental character of the neighbourhood in question. Exploration of what has been done elsewhere will be brought to bear on strategies for the transformation of Manor Park. These strategies, in turn, might be generalized to be made applicable to other, similar communities.

\section{Structure of the Thesis}

Chapter 1 provides background on post-war suburbanization, exploring how diverse influences such as housing policies, modern construction methods, and neighbourhood modules contributed to the now-ubiquitous suburban landscape. Early post-war communities such as Levittown and Don Mills proved so influential that many of their design and development strategies are still applied across North America. Housing in these suburbs took the form of simple, moderately priced starter homes within identifiable neighbourhoods. Over time the housing units have evolved through expansion and renovations to suit their owners needs, supported by a steady increase in property values. Since their inception, however, critics have raised concerns about the impact of these automobile-centric, low-density developments on our health and that of the natural environment. Partly in response to this, the thesis takes the position that suburban neighbourhoods can and should evolve over time to better suit their current and future residents.

Chapter 2 explores the development of Manor Park through an in-depth study of archival documents, including neighbourhood plans, Minutes of the Board of Control of the Corporation of the City of Ottawa and advertising materials. Together these resources provide the most complete record currently available of the development of Manor Park, including the design aspirations and evidence of how plans were altered as the community was built out. It includes a discussion of the evolving terms of reference by which suburbs are evaluated. The rise in property values is one of a number of factors that can affect how a community is perceived over time. Initially a prototypical community 
of affordable housing, Manor Park disappeared into an expanding tide of similar development. In recent years, however, there has been a renewed interest in these early suburban prototypes as artefacts worthy of study and even historical designation.

Manor Park stands on a precipice, facing strong redevelopment pressures that will affect its future. In concert with neighbouring development, it is important to pit history, continuity and a respect for residents against market pressures, governmental policies and current ideas about sustainability in order to guide future development. Chapter 3 examines how other communities have leveraged redevelopment to improve the quality of the environment and the quality of life of the residents.

In Chapter 4 the research method shifts to design, through which the topics covered earlier chapters are brought to bear on a demonstration plan for the redevelopment of the a portion of Manor Park. Informing the design process are 1) principles of sustainable growth (as laid out in the LEED ND and recent variations on Perry's neighbourhood diagram), 2) changes in demographics driving changes in housing preferences, 3) the City of Ottawa's directive to focus urban growth on areas within the urban boundary, especially those within the greenbelt, and 4) consideration of the impact of adjacent development on Manor Park, particularly the redevelopment of CFB Rockcliffe. It is hoped that strategies identified through formulation of this demonstration plan might, like Manor Park itself, serve as a prototype for the redevelopment of similar neighbourhoods.

Focussing on Manor Park Estates, the proposed demonstration plan is intended as a flexible and somewhat generic framework for the growth and transformation of the neighbourhood. It is my hope that this framework could suit the needs and desires of current residents while anticipating those of future generations. Supported by a variety of views and vignettes, a demonstration plan can be an important tool for community consultation and feedback. Future research, then, would include presentations to the community including neighbourhood associations, residents, and members of the real estate and development communities.

\section{Thesis Statement}

Using Clarence Perry's neighbourhood unit as a framework, the thesis explores ways of leveraging and channelling the development pressures facing mature suburbs in expanding metropolitan areas. Research on the topic includes a demonstration plan for the redevelopment of Manor Park, a prototypical post-WWII suburban neighbourhood in Ottawa, ON, with the goal of identifying strategies for accommodating change while enhancing the social stability, architectural character and environmental sustainability of the existing community. 


\section{Notes}

1. Kunstler, James Howard. "The Geography of Nowhere." In . New York: Simon and Schuster, 1996.

2. Provincial Policy Statement, Province of Ontario, http://www.mah.gov.on.ca/Page1485.aspx (accessed July 12, 2013).

3. "City of Ottawa Official Plan; 2.5.1 Urban Design and Compatibility." City of Ottawa. http://ottawa.ca/ en/official-plan-0/22-managing-growth (accessed April 12, 2013).

4. Ibid.

5. bid. 


\section{Chapter 1 Background}

\section{Introduction}

Coming out of WWII, North America faced severe housing shortages. Federal policies were put in place in both Canada and the U.S. to encourage homeownership. Houses for purchase generally took the form of single-family-detached homes. Many of the policies were based on earlier, Depression-era programs meant to stimulate the economy. Parameters for federally insured mortgages and construction loans included tight standards for cost, and construction. Projects that met these criteria were available to veterans with little or no money down. Builders were quick to respond to the demand for inexpensive homes for purchase, converting of large tracts of farmland into suburban communities. Levittown on Long Island, Don Mills in Toronto, and Manor Park in Ottawa are all examples of early post-war developments. A review of literature in this chapter will outline the history of post-war suburbanization through discussions about key policies, building practices, the neighbourhood unit and celebrated post-war suburbs.

\section{History of Post-War Suburbanization}

In Canada, federal policies encouraged house building by private initiative - in great part to use housing shortages as a way of making the transition from a wartime to a peacetime economy. C.D. Howe, a Canadian Cabinet minister, announced to Parliament in 1946, "It is the policy of this government to ensure that as large a portion as possible of housing be built by the private sector." ${ }^{11}$ One of the key instruments used by the Canadian government was the National Housing Act (NHA) of 1944, which created the Central Mortgage and Housing Corporation (CMHC). ${ }^{2}$ The CMHC was put in charge of housing, particularly the administration of federal loan programs. Federal loan programs were begun in the Great Depression, and included the 1936 Dominion Housing Act, and the 1938 NHA which both permitted the federal government to provide low-interest loans on approved new houses, the later act permitting loans for up to $90 \%$ of the cost house. ${ }^{3}$ Implementation of the 1944 NHA was meant to enable various parties to build a variety of housing forms by opening multiple streams of capital. ${ }^{4}$ The NHA proved to be more successful at encouraging the construction of single-family homes than rental housing. In the post-war period, the government also created the Integrated Housing Plan that further encouraged the construction of single-family dwellings by guaranteeing that the $\mathrm{CMHC}$ would buy back all unsold houses within a price limit. ${ }^{5}$ Continuing rent controls, as 
well as the evolution of the building industry to include industrial methods, made it more economical to supply modest private homes than rental housing. ${ }^{6}$ For the first time ever, with the help of government-backed longterm mortgages, private industry was able to reduce the monthly cost of owning a home to a level that was affordable to the majority of the population. Barriers to home-ownership were further reduced in the US, where veterans were guaranteed $0 \%$ down mortgages under the G.I. Bill.7

Prior to WWII, single-family homes were generally built for those in upper-income brackets and/or households who had managed to amass the funds required for steep down payments. Lower-income groups typically inhabited rental units within converted homes. With the exception of tenements in large cities like New York, this trickledown effect was the predominant way of providing housing for moderate-income households. But by building high volumes of modestly sized houses on inexpensive land on the suburban periphery, coupled with the use of construction methods honed during the war, builders were able to significantly reduce the cost of constructing single-family homes. Inexpensive houses, in tandem with government-backed, long-term mortgages, brought the purchase cost of a new house within reach of young veterans and their families. Housing is typically considered affordable if it consumes no more than a third of household income. Remarkably, as was the case in Levittown and Manor Park (to be discussed below), the monthly cost of purchasing a new home dropped to less than the cost of renting a comparable apartment.

The situation in which builders found themselves was entirely different from situations they would have encountered prior to the war. Humphrey Carver, who chaired the Research Committee of the Canada Mortgage and Housing Corporation (CMHC) and went on to serve on its Advisory Group, ${ }^{8}$ made a clear statement of the levels of homeownership in 1948,

"It must be realized that though home-ownership has been advertised as one of the virtuous aims of every Canadian householder, yet in normal times only about one-third of all urban households in Canada have been home-owners. The great majority of Canadian families do not expect to have to buy a house, and could not reasonably hope that their financial prospects would justify such a bold commitment." ${ }^{\prime 9}$

However, a change was occurring even as this statement was written. Carver provides statistics in Houses for Canadians describing the percentages of housing being built, "In the Toronto metropolitan area during 1945 and 1946, 89.7 percent of all units completed were single-family houses (a few of them semi-detached), only 3.4 percent were in the form of duplexes or apartments and 6.9 percent were conversions." ${ }^{10}$ These statistics show that there was a clear shift towards houses for ownership for all Canadians as, at the time, single-family houses were the only 
form of housing available for purchase. The same was true in the U.S.

Carver goes on to make a comparison between homebuilding and the use of an assembly line to manufacture cars "in a rational sequence so that the finished products can be brought to completion as economically and as rapidly as possible." ${ }^{11}$ During the war, contractors modernized building practices, making use of new, industrially made, standardized materials to rapidly build simple, standardized units of war worker housing. When coupled with national housing policies, these new construction methods enabled the rise of "a new breed of builder: large-scale, economy-and efficiency conscious, capable of building houses like refrigerators or cars." ${ }^{12}$

Large-scale builders, often termed "merchant builders," tended to produce large, suburban tracts of similar, modestly sized houses. The location of these neighbourhoods on suburban periphery not only reflected the economics of mass construction and inexpensive land but responded to longstanding anti-urban sentiment among the middle-class. According to Gwendolyn Wright, inherent in the anti-urban sentiment was, "a conviction that the suburbs were, in fact, the right place to raise a family, that city streets and older, inexpensive housing were dangerous to body and spirit."13 Additionally, numerous roads and parkways had been built under Depression-era programs, opening suburban areas to development.

\section{The Neighbourhood Unit and its Early Application}

Planners, saw the need for new housing as an opportunity to develop new patterns of urban growth, organized around neighbourhood modules. This vision had its roots in Clarence Perry's neighbourhood unit.

"The concept of the neighbourhood unit... Based on the then-popular notion of separation of land uses and the segregation of vehicular and pedestrian traffic, it emphasized boundaries and an inwardly focused core. Thus, it was cellular and it was relatively self-contained to be used in building-block fashion to construct a larger urban realm of communities." ${ }^{14}$

Developed at a meeting of Sociological and Community Associations in 1923 and published in 1929 as part of the Regional Plan of New York and Its Environs, Perry's neighbourhood unit diagram (Fig. 1) described a residential neighbourhood of approximately a quarter mile in radius. ${ }^{15}$ The dimension related to comfortable five-minute walking distance from center to edge, appropriate to an era predating mass car ownership. The arterials at the perimeter were meant to capture all of the through traffic, allowing the somewhat discontinuous internal street system to be pedestrian friendly inasmuch as it accommodated only slow moving local traffic.

Perry sized his neighbourhood for a population of about 8,800 people, sufficient to support the elementary school that he 
placed at the center. ${ }^{16}$ With an area of 160 acres, this translates to an overall density of around 55 people per acre (or 12.5 units per acre) in each neighbourhood unit. The arterial roads that formed the seams between different neighbourhood units supported commercial activity as well as higher-density, rental housing in the form of apartments. Buildings along the arterials accounted for some 32 percent of the housing units. ${ }^{17}$ The

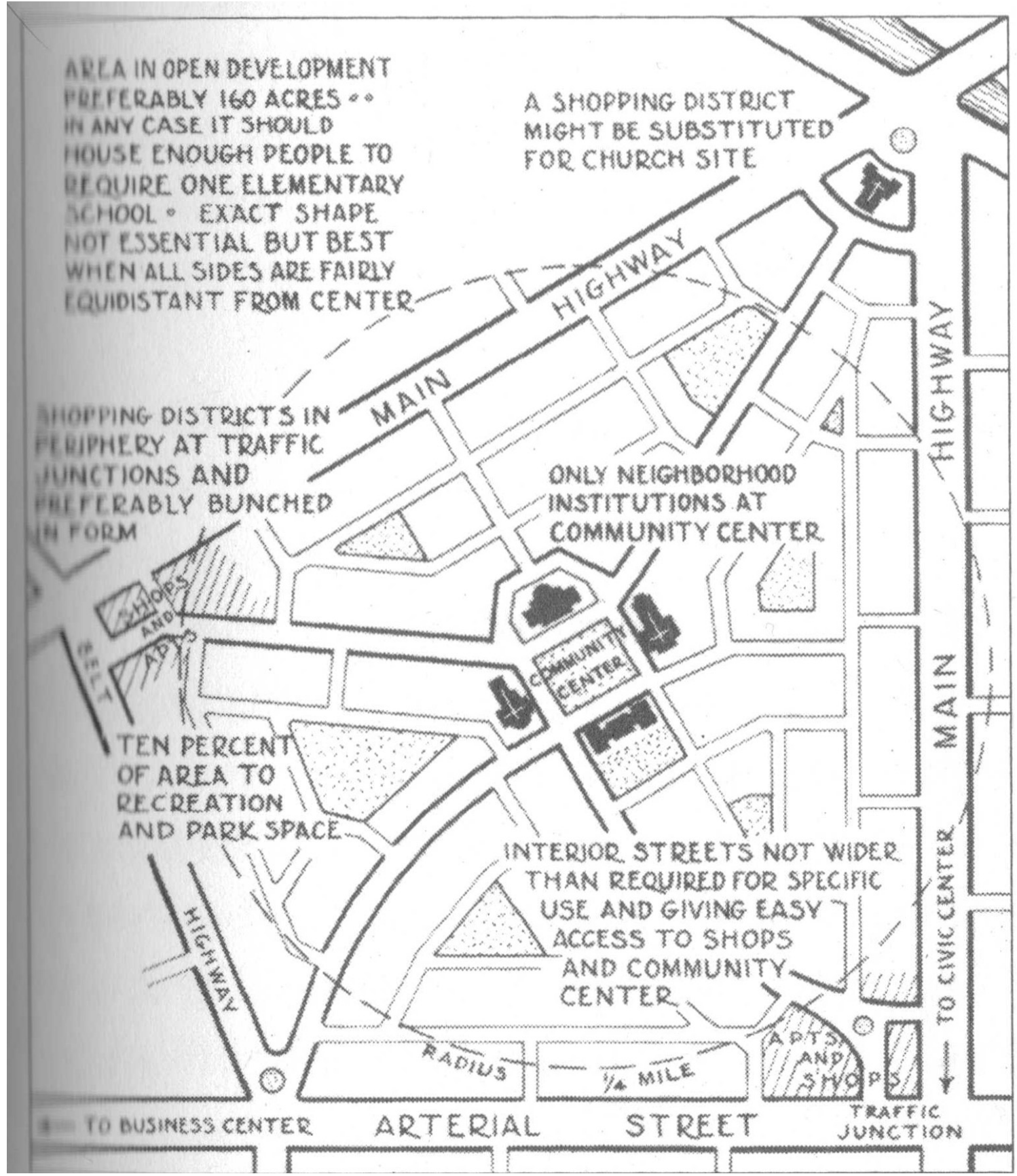

Figure 1: Perry Neighbourhood Unit, 1929 
combination of for-sale and rental housing types within the same neighbourhood produced a mixed-demographic community.

\section{Radburn, New Jersey}

Around the time of the publication of Perry's neighbourhood diagram, construction began on the community of Radburn, New Jersey, designed by Clarence Stein and Henry Wright. According to Stein, "At Radburn, I believe the modern neighbourhood conception was applied for the first time and, in part realized in the form that is now accepted." ${ }^{18}$ Figure 2 shows how Radburn was conceived of as a community of three overlapping neighbourhoods. Consistent with Perry's ideals, each neighbourhood was organized around an elementary school that the population of the neighbourhood (between 7500-10000) was designed to support. ${ }^{19}$ The primary difference between Radburn and Perry's diagram relates to the overall area. Radburn, the self-styled suburb "for the automobile era," called for each neighbourhood to have a radius of a half mile, nearly four times the area of Perry's neighbourhood unit.

Radburn's three neighbourhoods were designed to overlap in order to share services beyond what individual neighbourhoods could support. These included the high school that was placed at the center and larger-scaled commercial centers. Humphrey Carver, agreed with the premise of Radburn's community of neighbourhoods. In his 1965 book, Cities in the Suburbs, he wrote,

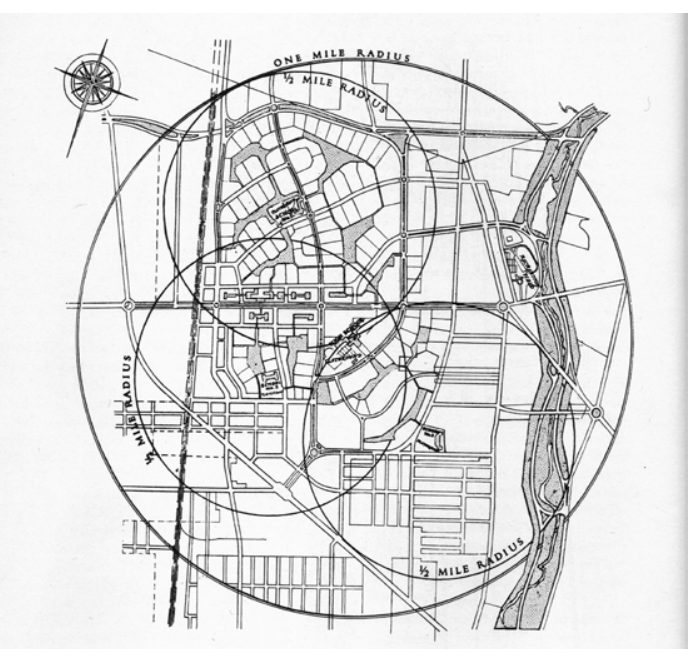

Figure 2: Radburn Community Plan

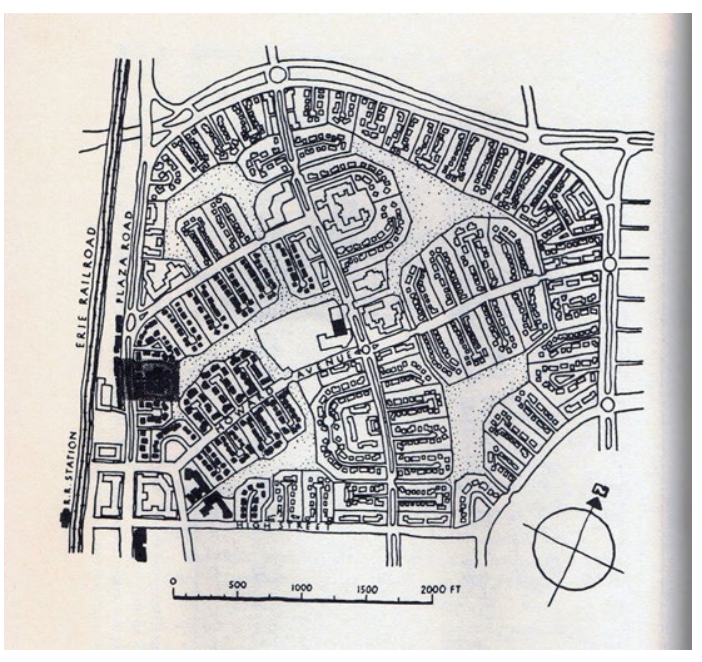

Figure 3: Radburn Neighbourhood Plan

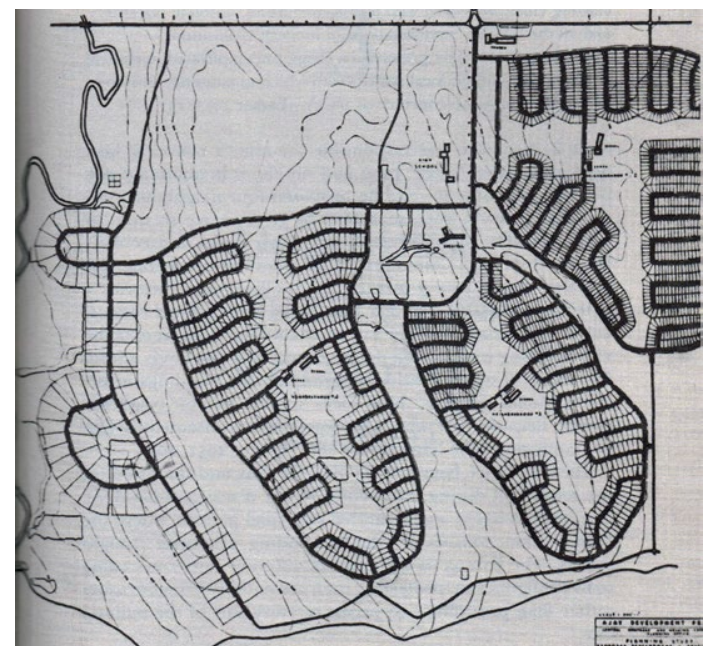

Figure 4: Plan of Ajax, Ontario 
"The population that supports one elementary school is not large enough to support the principal social and commercial services on which suburban life depends. The populations of three or four neighbourhoods together provide a reasonable economic demand for these services: the shopping centers, places of gathering and entertainment, and clusters of apartment housing." 20

By overlapping the neighbourhoods, Stein and Wright anticipated areas of greater concentrations of population that would include higher-density housing (apartments and row houses) along the arterials. ${ }^{21}$

In the design of Radburn, Stein and Wright took the circulation patterns to a level beyond Perry. Neighbourhoods were organized into superblocks into which a series of residential cul-de-sacs pushed (Fig. 3). Houses along these cul-de-sacs were designed to face onto back gardens abutting a continuous green common through the center of each superblock. Through this common, Stein and Wright designed a series of pedestrian paths leading to the elementary school and to key points along the periphery. Underpasses were provided such that children would never need to cross a road or confront motorized vehicles as they moved through the community. ${ }^{22}$

Due to the onset of the Great Depression only two of Radburn's three neighbourhoods were begun, and neither was completed (Fig. 4). Nonetheless, Radburn's design proved to be extremely influential. Among the many communities for which Radburn was used as a model are two in Ontario, namely Ajax (Fig. 3) and Don Mills. Ajax, constructed in 1941 as war worker housing for a munitions plant, was designed with looping streets to create a continuous, Radburn-like park system at the center of each superblock. Don Mills will be discussed in greater detail below. ${ }^{23}$ (Fig. 10)

\section{The Neighbourhood Unit Adapted to Post-WWII Suburbs}

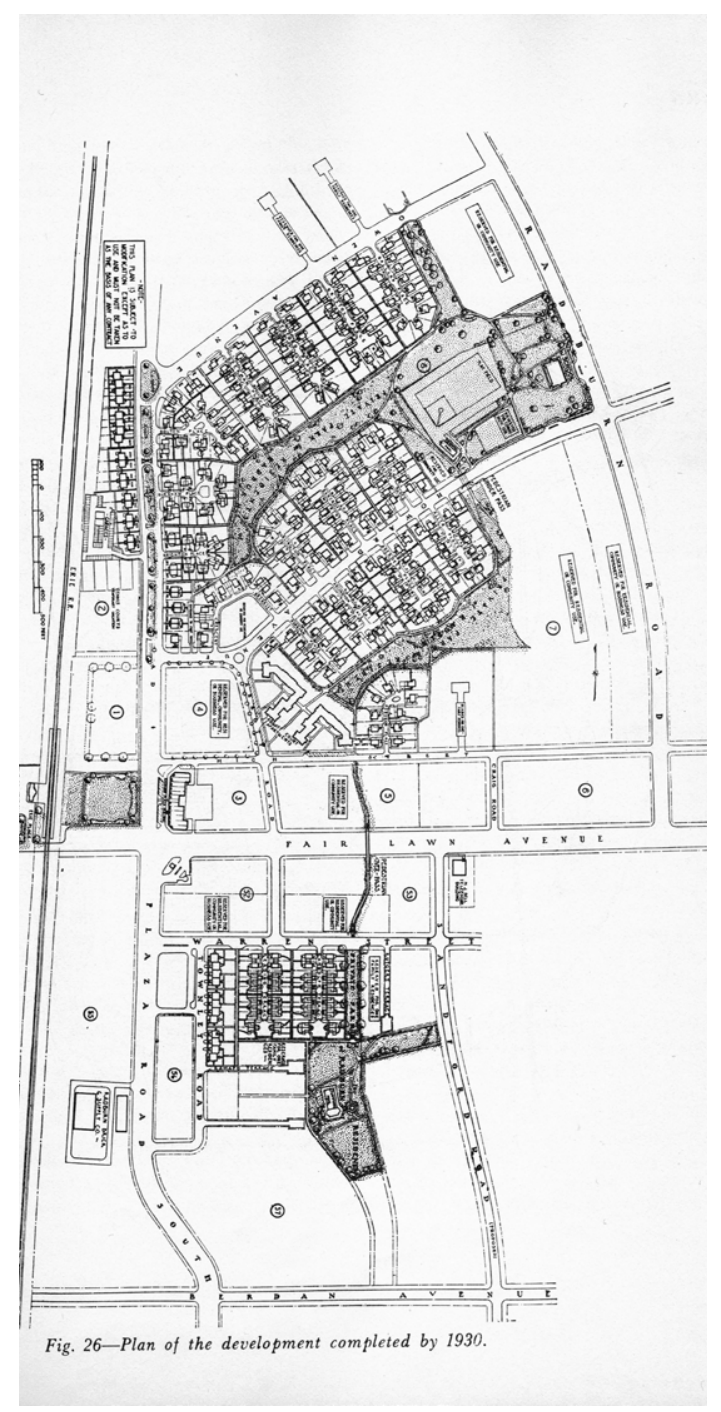

Figure 5: Plan of Radburn as completed, in 1930 
In his 1948 book, Housing for Canadians, Carver argues that it is important to consider the arrangement of the community as a whole when designing homes. ${ }^{24} \mathrm{His}$ vision of a neighbourhood community corresponds in many ways to Perry's neighbourhood unit. Like Perry, Carver puts the number of units in a neighbourhood at about 2,000, but his target population density (30 people per acre) was about half that of Perry's. The lower density target can be explained by two factors, namely fewer people per household than Perry assumed, and a larger overall area. Based on an analysis of Toronto neighbourhoods Carver determined that new neighbourhoods should be about 250 acres - about half again as large as Perry's 160 acres. The increase in area related both to the apparent vastness of the Canadian landscape and to the high prevalence of car ownership after WWII.

Carver advocated neighbourhoods that included both a mix of demographic and a mix of uses.

"The design of a neighbourhood, containing a variety of dwelling types and a variety of other buildings required to serve the community, cannot be effectively expressed on a zoning map; there is a danger that zoning control will itself merely impose a sterile uniformity upon residential areas." ${ }^{25}$

Like Perry, he also envisioned that a neighbourhood could support an elementary school as well as a variety of shops. He felt that an average-sized neighbourhood with a population of around 7,500 people should be able to support around 40 shops with a frontage of about 1,400 feet. Carver favoured compact shopping centers located at strategic points rather than the more traditional "main street" (or commercial strip) arrangement of businesses organized along arterials. ${ }^{26}$

\section{Levittown, Long Island}

Levittown, Long Island, one of the earliest and best-known post-WWII suburbs, was begun in 1947. Its location in Hempstead, a suburb of New York City, was made possible by relatively high rate of car ownership coupled with its proximity to the Wantagh State Parkway, constructed by Robert Moses as a make-work project during the Depression. ${ }^{27}$ Initially envisioned as rental housing, Levittown was built by the firm of Abraham Levitt and Sons (William and Alfred), which developed key construction techniques

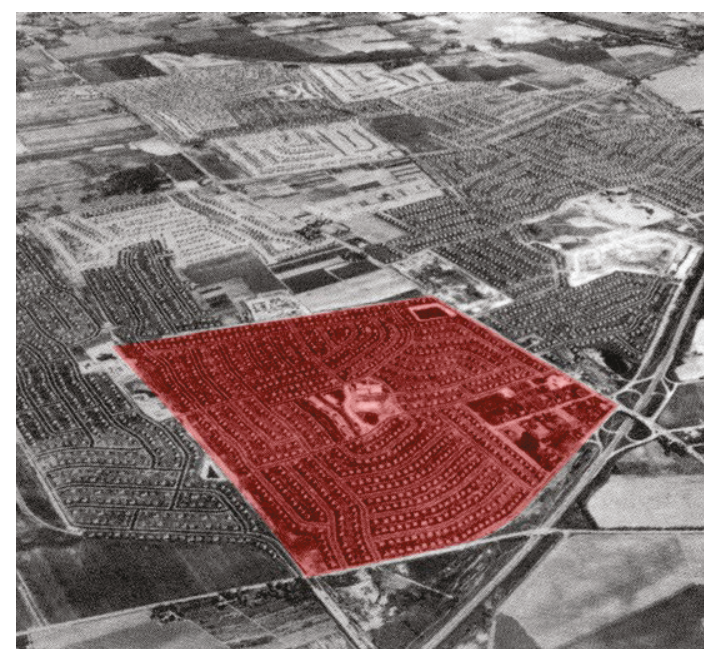

Figure 6: Aerial view of Levittown under construction 
during the war when commissioned to build war worker housing quickly and efficiently. The build-out of Levittown's development has been compared to an industrial assembly line as, the Levitt's techniques included "Flow production, division of labour, standardized designs and parts, new materials and tools, [and] maximum use of pre-fabricated components." 28

As in Canada, the construction of Levittown was in large part made possible by government programs and policies. It, too, bears the influence of Perry's neighbourhood unit. In her 1993 book, Expanding the American Dream, Barbara M. Kelly explains that:

"At the federal level [in the U.S.], the FHA [Federal Housing Administration] set minimum standards for cost, structure, and style and then insured the economic risk for those lenders who underwrote the construction of the development. The lenders, in turn, working under federal guidelines, established the terms of

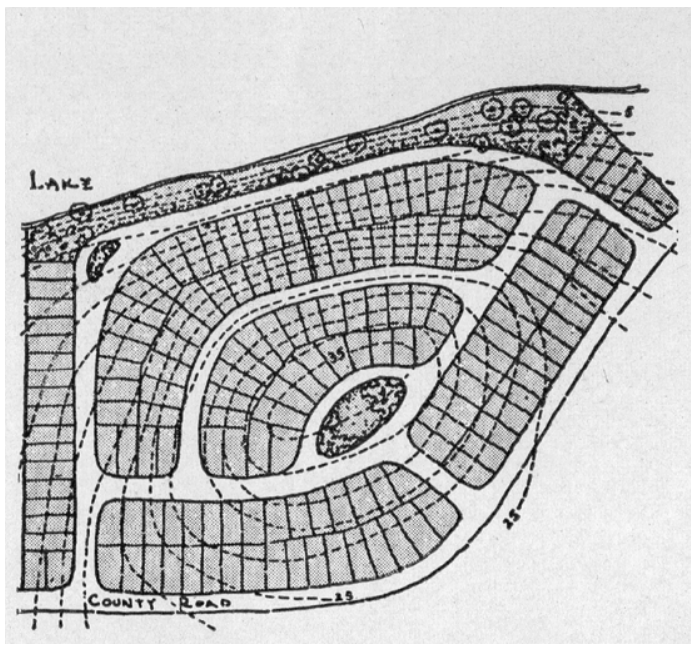

Figure 7: FHA diagram recommending streets follow topography the economic investment. Finally, the builder/developers, working within the constraints established by these agencies, selected materials, colours, design and location." 29

Among other things, Levittown is renowned for the speed at which it was built out. While it has been criticized for being nothing more than a large collection of streets lined by repetitive houses, ${ }^{30}$ Levittown was organized into of a series of neighbourhood units, much like those at Radburn. The individual neighbourhood units are apparent in a 1948 aerial photograph of the development's first 6,000 houses (Fig. 6). As indicated by the highlighted area, single-family dwellings are organized around a central school and framed by arterial streets. The Levitts built shops along the arterials, as well as in "village greens" (visible in the community plan as the larger spaces) that also included swimming pools

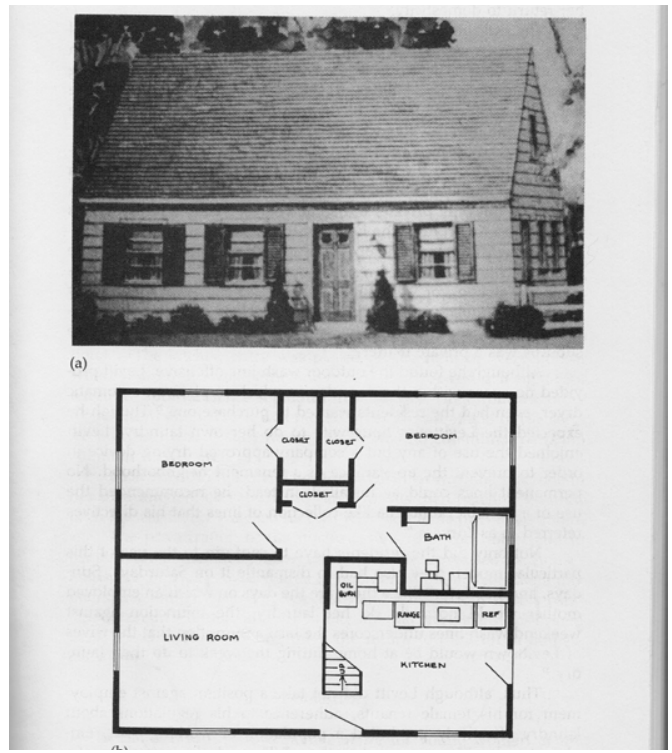

Figure 8: Architects rendering of Levittown Cape Cod and Floor plan of Cape Cod by Kelly, Barbara M. 
and community halls. Because the smaller-scale neighbourhood shops proved not to be profitable, likely because net densities were not high enough to support them, they were sold and often redeveloped into apartments. ${ }^{31}$ Other parcels were transferred to the community for schools, churches, libraries and other public facilities. ${ }^{32}$

Further analysis reveals the curvilinear layout of the streets, a form that deters through traffic and slows the speed of traffic, consistent with Perry's ideal of pedestrian friendly internal streets. The Levitts also drew inspiration for their street layout from design guidelines published by the FHA such as the Successful subdivisions; planned as neighbourhoods for profitable investment and appeal to homeowners pamphlet produced in 1941. (Fig. 7) In this publication the FHA recommends that curvilinear street patterns be based on topography, that streets intersect at right angles, and that " $T$ " intersections be used in place of 4-way intersections. ${ }^{33}$ It is interesting that the first 2,000 houses built at Levittown corresponds exactly to the number of units that Perry had envisioned for his neighbourhood unit. However, the Levittown homes were distributed over about 300 acres, that is, at roughly half the density of Perry's neighbourhood unit. Again, this reflects the emphasis on vehicular over pedestrian movement through the subdivision, commensurate with the high rate of car ownership and the suburban ideal of "elbow room."
The first 2,000 houses to be built were Cape Cod style, rental houses (Fig 8). ${ }^{34}$ According to Barbara Kelly, the simple four-room design was a considered to be "a reduction of the prewar middle-class house to a culturally acceptable minimum that made it affordable for a market which was younger and less affluent then its prewar home-owning counterpart." ${ }^{35}$ The provision of rental housing, fit with previous cultural traditions, but was seen by the Levitts as a short-term solution to providing housing. Due to continuing rent controls, and the modernization of building industry, the Levitts - and other builders determined it was more profitable to supply modest private homes for purchase than for rent. ${ }^{36}$ Soon after construction began, the Levitts changed their business model and began selling off houses to free up capital for additional for-sale houses. By 1948 Levittown had expanded to 6,000 Cape Cods. Following on the success of the initial sales, the Levitts

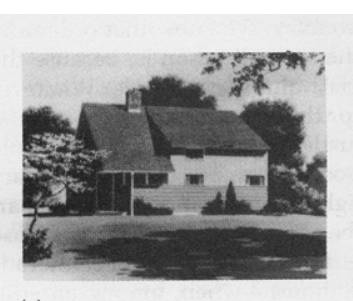

(a)

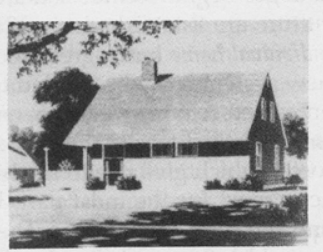

(e)

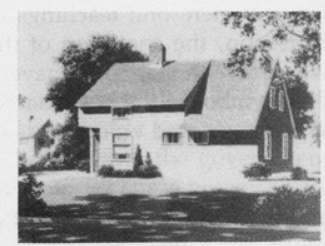

(b)

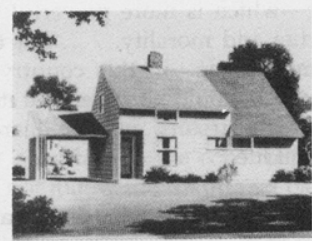

(f)

Figure 9: Architects rendering of Levittown ranch models 1949-51 
shifted to a ranch style of housing in 1949

(Fig 9). While similar in size to the Cape Cod, the new homes had a more modern elevation and an updated floor plan designed to appeal to the market for modest, proprietary housing. ${ }^{37}$

By the end of the construction, Levittown, Long Island comprised 17,447 new houses ${ }^{38}$ and a corresponding number of young families. The homogenous housing attracted an equally homogenous population of young white couples. The Levitts targeted blue-collar and aspiring white-collar workers, which, as noted, represented a new market for homeownership. With an initial selling price of $\$ 7,500$, homes would have been affordable to families with an annual income of at least $\$ 3,750$, depending on their down payment. ${ }^{39}$ The Levitt's were particularly successful at selling their units quickly through the use of advertising that promoted not only the product, but the financing. Ads "Promised no down payments, no closing costs, and 'no hidden extras.'"40 Such advertising would have been directed at veterans who, under the 1944 Veteran's Mortgage Guarantee Program (better known as the Gl Bill), could purchase a house with no money down. The choice between purchasing or renting in Levittown was simplified by the comparison between the monthly payments. Based on a 25-year mortgage, the monthly cost to purchase was $\$ 52$ compared to $\$ 60$ to rent. ${ }^{41}$ Between high demand, good marketing, easy credit, and low monthly payments, the houses in Levittown sold quickly, and were so successful that the Levitts went on to construct two more Levittowns.

\section{Don Mills}

In 1952, five years after construction had begun on Levittown, Long Island, the model community of Don Mills was begun northeast of Toronto. Don Mills was designed by Macklin Hancock to be a mixed use and mixed-tenancy community on a 2063-acre site owned by the developer, E.P. Taylor. John Sewell observes that

"Five concepts informed [Macklin] Hancock's remarkable plan: neighbourhoods, a discontinuous road system, a profusion of green space, new house forms and new lot configurations, and a separation of uses and activities." ${ }^{42}$

As seen in the plan (Fig 10), the four quadrants/neighbourhoods in Don Mills, each based on Perry's diagram, are separated by arterial streets (Don Mills Rd. and Lawrence

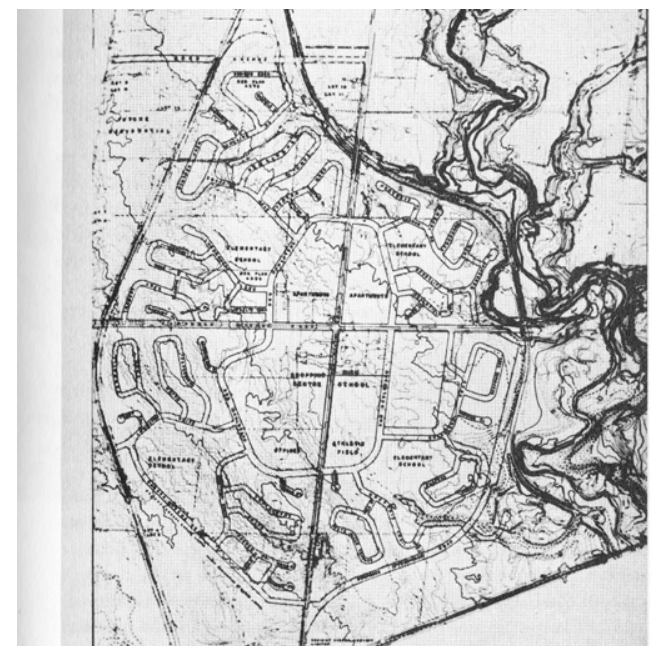

Figure 10: Don Mills Plan 
Ave.). At the center of each neighbourhood is an elementary school surrounded by a park. An internal pedestrian pathway system, strongly influenced by Radburn, enables children to reach the school without crossing roads. ${ }^{43}$ Community-wide facilities such as a shopping center, high school, library and community center were placed within a ring road at the center of the four neighbourhoods. Meanwhile, industrial uses were located at the perimeter of the neighbourhoods, primarily in the southeast quadrant. ${ }^{44}$

To enable mixed-tenancy within the community, Hancock planned for a mix of housing types. Just over half (55\%) of the units were organized into three storey apartment buildings, many of which were located within the ring road to the North of Lawrence Ave, while the remainder of units were a mix of single-family, semi-detached and row houses. While the mix of tenure and housing types was intended to accommodate a mixed demographic, the strategy was not entirely successful. As certain two-bedroom, semi-detached units intended for low-income families were considered too small by the North York Council, their construction was blocked. Also, housing intended to be rented to $\mathrm{CMHC}$ for low-income families was stopped when parties could not come to an agreement. Those constructed went on to be rented at a much higher rate. ${ }^{45}$ Meanwhile, the neighbourhoods were so popular with upwardly mobile young families that they soon became homogeneous.
When completed in 1961, the population of Don Mills reached 29,000, most of which was middle-class. If divided into four, the population of each of the neighbourhoods approximated the number of residents that Carver recommended for his neighbourhood units. ${ }^{46}$ With an overall density of only 14 people per acre (PPA), however, Don Mills was substantially lower in density than either Perry or Carver had recommended. That said, it was about double the density of Levittown. This discrepancy can partially be attributed to the large industrial areas on the perimeter of Don Mills, a use that neither Perry or Carver accommodated in their neighbourhoods. More likely, however, the low density relates to the wide lots on which single-family houses were located (deducting the industrial area from the calculation only slightly increases the PPA to 16.6). By comparison, Radburn had a similar population density of between 15-20 PPA.

Additional design aspects helped to set Don Mills apart from other local developments. Like Levittown, Don Mills favoured discontinuous streets ending in " $T$ " intersections. As the FHA promoted this kind of street planning to keep through traffic to a minimum, it is likely that the CMHC would have also promoted " $T$ " intersections for Canadian developments. Given its extensive system of green corridors, almost $20 \%$ of the land in Don Mills was given over to parks ${ }^{47}$ - about twice the amount recommended by Perry. While areas within each of Don Mills' neighbourhoods were designated for retail, mostly in the 
form of corner stores, the population was too low to support them and the areas were built out as residential instead. ${ }^{48}$ Commercial uses were confined to the southwest corner of Don Mills and Lawrence, at the center of the community.

Although Don Mills respected the ideals of the neighbourhood unit, it is better known for its innovations in subdivision and development practices, including land sales and servicing. ${ }^{49}$ Taylor chose to sell groups of lots to builders for a down payment of $25 \%$, with the remainder of the cost being due after 18 months. This both freed up the cash flow for builders and encouraged them to build out their parcels quickly. Additionally, if work was not completed rapidly enough, Taylor reserved the option to step back in. From a servicing point of view, in order to get approval for his development, Taylor agreed to cover the cost of a new sewage treatment plant. He further reduced the financial risk to the municipality by buying North York bonds to finance the water service. All of the internal servicing of Don Mills was also done at the cost of the developer (a growing practice not done in Manor Park). ${ }^{50}$

Radburn, Levittown, and Don Mills are each examples of communities that applied the neighbourhood unit as a building block for urban growth. Levittown and Don Mills (as well as Manor Park, discussed in the following chapter) were viewed as prototypical developments that embodied the practices encouraged by government policies in the post-war era. They set the patterns emulated (although frequently denatured) by the merchant builders responsible for suburbia across North America. These builders were able to leverage long-term, low-interest loans, inexpensive land, widespread automobile ownership, government-funded road infrastructure, and a high demand for housing in the post-war decades..$^{51}$ Despite fluctuations in the production of suburban housing in the intervening decades, new suburbs continue to use the neighbourhood unit as a basic building block. As a result of half a century of automobile-based suburban expansion, neighbourhoods like Levittown and Don Mills that were once on the far periphery are now considered part of the core urban area. To curb low-density, infrastructure-intensive expansion, many cities, including Ottawa, have chosen to direct growth to areas within the existing urban boundary. Cities are, in other words, advocating for the intensification of existing urban areas. Among other things, intensification makes better use of infrastructure, makes alternative forms of transportation viable, and helps preserve green space and farmlands on the periphery.

\section{Toward a More Sustainable Form of Development}

The passage of time has seen numerous changes affecting neighbourhood development, both new and infill. Among them are changes in retailing patterns and practices. The increase in the number of brands and formats available, coupled with further 
increases in car ownership, has forced grocery stores to expand both the shelf space available and the amount of parking they provide. Already by 1965, Carver observed that "a store must seek the business of a community of 3,000 to 5,000 families, a population of about $20,000 .{ }^{\prime 52}$ By the mid 1960 s, then, stores required two to three neighbourhoods to sustain their business. Since then size of retailers and their catchment areas have continued to expand. Farr suggests that small convenience centers $(10,000-30,000$ square feet or $929-2,787 \mathrm{~m}^{2}$ ) would require at least two traditional neighbourhoods to support business, while a "neighbourhood center" that includes a grocery store, would require six to eight neighbourhoods..$^{53}$ More recently, cities have seen the rise of supersized box stores that require an even larger floor areas for their building and parking, and a correspondingly larger population to service. As this kind of shopping development is out of proportion with typical neighbourhood and infill construction, it poses challenges for the idea of a walkable, mixed-use community. Current ideas on the location for retail is that it should be placed in an area that is easily accessible by multiple neighbourhoods so that it can be successful, and that it should be located in such a way that it can be accessed by walking, biking or transit as well as by car. All of this requires high residential densities.

Over time there has also been a shift in demographics, including a significant increase in the number of households (headship rate) coupled with a drop in the average size of households. Among the demographic groups to emerge are older couples whose children have moved away (known as Empty Nesters), young professional singles (YUPPIES), and young, two-income households without children (a.k.a. DINKs). Douglas Farr provides figures for these groups in the U.S., namely, "82 million Baby Boomers, born between 1946 and 1964, and the 78 million millennials, who were born from 1977-1996," ${ }^{154}$ which, as a proportion of the total population, should be the same for Canada. While these groups are distinctly different from each other, they share many of the same space requirements. Yuppies and Empty Nesters typically have households made up of one to two people, and can be best accommodated in small units, often on a single level. They are easily housed in apartments or condominiums especially if these are located near shops, transit and other amenities. Indeed the urban condominium has replaced the Levittown Cape as the starter home of the $21^{\text {st }}$ century. The rise of the condominium designation in the late 1960s in the U.S., is another important change, that has, and will continue to influence the shape of neighbourhoods. According to Ned Eichler, "Under this concept (a legal not physical idea) one could own a dwelling and only an undivided interest in the land under it. In a multistory building, for example, a legal description could be made that was a kind of vertical, three-dimensional tract map." ${ }^{55}$ Canada soon followed the U.S., in implementing condominiums. The 
first registered condo in Canada was a townhouse development in Edmonton in 1967, while the first high-rise condo appeared two years later in metropolitan Ottawa. ${ }^{56}$ The addition of the condo designation in Canada made it possible for first-time buyers - generally individuals and couples without children - to purchase a unit within a multiunit building. Prior to this the only form of housing available for purchase was the single family home, hence the proliferation of this form in the post-war decades, and the decision to buy meant the decision to move to the suburbs. The condo designation enables planners to include a more diverse array of ownership possibilities within a neighbourhood. It can also be used to further integrate various income groups, as a condominium tower can be placed harmoniously next to a rental apartment tower.

Coincidentally the rise in interest in condominiums - driven largely by demographics - corresponded with a rise in concerns related to the environment. Ned Eichler writes that "By 1969 citizens all across the country were coming to believe in the environmental crisis." ${ }^{57}$ While conservationists were at first interested primarily in single issues such as cleanliness of water supplies, with the drastic rise in gas prices in the $1970 s^{58}$ shifted the focus to the overall impact of human development on the environment. ${ }^{59}$ As will be discussed in Chapter 3, what is commonly referred to as the "sustainability" movement is exerting an increasingly important influence on urban design and the shape of the built environment.

\section{Conclusion}

Following many of the principles established by Perry's neighbourhood diagram and encouraged by government programs and policies, low-density suburban neighbourhoods proliferated in the second half of the $20^{\text {th }}$ century. As they mature, these neighbourhoods face increasing development pressure. This pressure reflects new opportunities for ownership (e.g. condominiums), demographic changes and heightened environmental awareness. It also stems from provincial policies that encourage intensification. However inevitable, the transformation and intensification of established neighbourhoods must be carefully and sensitively considered, taking into account each neighbourhood's history, character and sense of itself. The following chapter will explore the design and development of Manor Park by way of establishing a basis for a demonstration plan for the transformation of the neighbourhood, going forward.

\section{Notes}

1. Sewell, John. Houses and Homes; Housing for Canadians James Lorimer \& Company, Publishers, Toronto, 1994, 7-8.

2. Later known as Canada Mortgage and Housing Corporation

3. Ibid., 84-85.

4. Carver, Humphrey. Houses for Canadians; A Study of Housing Problems in the Toronto Area University of Toronto Press, 1948, 10-11.

5. Sewell. Houses and Homes, 90.

6. Carver. Houses for Canadians 8 and 47. 
7. Jackson, Kenneth T. Crabgrass Frontier; the suburbanisation of the United States. New York, NY: Oxford UP, 1987, 219-245

8. Carver held these positions between 1948-55 and 1955-67 respectively.

9. Carver. Houses for Canadians 8.

10. Ibid., 47.

11. Ibid., 39.

12. Hall, Peter. Cities of Tomorrow. Third Edition ed. (Oxford, UK: Blackwell Publishing, 2002), 319-320.

13. Wright, Gwendolyn. Building the Dream; A Social History of Housing in America. 3rd ed. (Cambridge Massachusetts; London, England: The MIT Press, 1988), 218.

14. Banerjee, Tridib and William C. Baer. Beyond the Neighbourhood Unit; Residential Environments and Public Policy. Environment, Development, and Public Policy., edited by Lawrence Susskind. (New York: Plenum Press, 1984), 2.

15. Hall. Cities of Tomorrow, 130.

16. Perry, Clarence. "The Neighbourhood Unit." Chap. II., In Regional Survey of New York and its Environs. Volume VII ed., (New York: Arno Press, 1974), 40.

17. Ibid.

18. Stein, Clarence S. "Radburn." Chap. 2, In Toward New Towns for America. Third ed., 37-74. (Cambridge, Massachusetts: The M.I.T. Press, 1969), 48.

19. Ibid., 51.

20. Carver, Humphrey. Cities in the Suburbs University of Toronto Press, 1965, 60.

21. Stein. "Radburn." Chap. 2, In Toward New Towns for America. Third ed., 51.

22. Ibid.

23. City housing Corporation, Radburn's developer, went into bankruptcy because the financial success of the development depended on large scale sales to offset carrying charges and development fees such as road construction and utilities. Depression slowed improvement and sales but not carrying charges. From Stein, Clarence S. "Radburn." Chap. 2, In Toward New Towns for America. Third ed., 37-74. (Cambridge, Massachusetts: The M.I.T. Press, 1969), 68.

24. Carver. Houses for Canadians, 23.

25. Ibid., 43 .

26. Ibid., 40-42.
27. Hall. Cities of Tomorrow, 298.

28. Ibid., 320 .

29. Kelly, Barbara M. Expanding the American Dream; Building and Rebuilding Levittown. (Albany, N.Y.: State University of New York Press, 1993), 47.

30. Sewell, John. The Shape of the City: Toronto Struggles with Modern Planning. (Toronto, Canada: University of Toronto Press Incorporated, 1993), 81.

31. Dunham-Jones, Ellen and June Williamson. Retrofitting Suburbia; Urban Design Solutions for Redesigning Suburbs. Hoboken, New Jersey: John Wiley \& Sons, Inc., 2009, 51.

32. Kelly. Expanding the American Dream, 33.

33. Ferguson, Abner. Successful Subdivisions; Planned as Neighborhoods for Profitable Investment and Appeal to Home Owners. Land Planning Bulletin no. 1., edited by Federal Housing Administration. Washington, D.C.: U.S. Government Printing Office, 1941, 15 and 17.

34. Kelly. Expanding the American Dream, 21. The rental community was initially known as Island tree, the name was only changed to Levittown in April of 1948 (p. 50)

35. Ibid., 12.

36. Carver. Houses for Canadians, 8 and 47.

37. Kelly. Expanding the American Dream, 42.

38. Ibid., 33.

39. Ibid., 45

40. Jackson, Kenneth T. Crabgrass Frontier; the Suburbanization of the United States. New York: Oxford University Press, 1985, 236.

41. Kelly. Expanding the American Dream, 31.

42. Sewell. The Shape of the City, 82.

43. Ibid., 88 .

44. Ibid., 86.

45. Ibid., 90.

46. Ibid., 91

47. Ibid., 88.

48. Ibid., 91.

49. Ibid., 93.

50. Ibid., 94-95. 
51. Eichler, Ned. The Merchant Builders. Cambridge, Massachusetts: The MIT Press, 1982, 5-6.

52. Carver. Cities in the Suburbs, 82.

53. Farr, Douglas. "Sustainable Neighbourhoods." Chap. Chapter 7, In Sustainable Urbanism; Urban Design with Nature, 124-167. Hoboken, New Jersey: John Wiley \& Sons, Inc, 2008, 140.

54. Ibid., 134.

55. Eichler, Ned. The Merchant Builders. Cambridge, Massachusetts: The MIT Press, 1982, 141.

56. Thomas, Rob. "Highrise Condo a Canadian First."Sun Media. http://www.ottawasun.com/news/ ottawa/2009/08/10/10419716.html(accessed April, 15, 2013).

57. Eichler. The Merchant Builders, 180.

58. "Slaying the Dragon of Debt; Fiscal Politics and Policies from the 1970's to the Present; 197374 Oil Crisis." The Regents of the University of California. http://bancroft.berkeley.edu/ROHO/ projects/debt/oilcrisis.html (accessed May 9, 2013).

59. Eichler. The Merchant Builders, 181. 


\section{$\frac{\text { Chapter } 2}{\text { Manor Park }}$}

Ottawa's Manor Park neighbourhood is to Canada what Levittown is to the U.S. Located south of the Rockcliffe Parkway along the Ottawa River and immediately east of Rockcliffe Park, the community wraps around Beechwood Cemetery to the north and east. Manor Park is arguably the earliest prototypical, post-war suburban neighbourhood in Canada. It has been selected as a study on the assumption that portions of it are likely to undergo redevelopment in the immediate future. Conceived as a model for post-war suburbanization and located in the Nation's Capital, Manor Park is well positioned to once again guide the adaptation of suburban communities into a form that will endure into the future. While a demonstration plan for redevelopment will be discussed in Chapter 4, an overview of Manor Park will set the stage.

Comprising about 245 acres, Manor Park, like Levittown, developed rapidly in the late 1940s. Both communities, based on groupings of neighbourhood units, were envisioned as examples of the form that suburban development should take. Regardless of the experimental nature of Manor Park, there was little risk to the developer as a result of the Integrated Housing Plan (IHP) of 1944. As noted above, under the IHP, CMHC guaranteed to buy unsold houses from builders who constructed housing according to CMHC guidelines. ${ }^{1}$ Manor Park Reality Ltd. drew up plans for Manor Park's first phase, in 1946. Approvals were quickly granted, followed by land assembly (facilitated by the municipality - first Gloucester Township and later the City of Ottawa), ${ }^{2}$ and construction of approximately 700 units in the first phase began early the next year.

\section{Overview of the Planning of Manor Park}

Like Levittown and Don Mills, Manor Park is a private suburban development that was planned to be mixed-use, following design principles articulated in Perry's neighbourhood unit. Built in two phases, the first

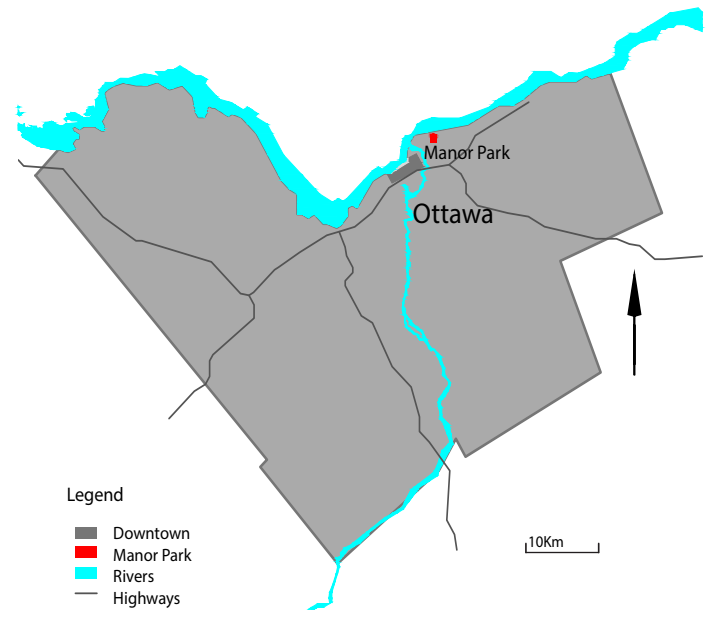

Figure 11: Map locating Manor Park area in Ottawa 
proposal for Manor Park corresponds closely to Perry's neighbourhood unit. As seen in the diagram (Fig. 17) , Phase 1 of Manor Park included a large percentage of single-family dwellings in close proximity to an elementary school, a park, a shopping plaza and an area of rental terrace houses. The total area of roughly 125 acres was enclosed by a series of existing arterial roads (Hemlock Rd., Baseline Rd. currently known as St. Laurent Blvd., Sandridge Rd. and Birch Ave., fig. 12). The existing road infrastructure made this site easily accessible by automobile as all of the roads mentioned above, with the exception of Birch, connected the area to previous developments in Ottawa and Gloucester.

When the design for Manor Park was conceived, the concept of developing a large plot of land and constructing multiple houses from a limited number of designs was new. Prior to WWII the processes of subdividing land and homebuilding were largely separate, with individual lot buyers taking responsibility for the construction of their homes. The developer, Manor Park Reality Ltd., solicited municipal help to assemble the necessary land for the project. Being concerned about severe housing shortages in the Ottawa area - particularly affordable housing - the municipality of Gloucester agreed to expropriate the area in question and sell it to Manor Park Reality Ltd. at cost. Controversy over this course of action led a public inquiry resulting in the Seymour Report of 1953. In his decision, Commissioner M.A. Seymour Esq. Q.C. determined that the use of expropriation was valid given the gravity of housing shortages in the area. He wrote:

"In order to re-design, or provide a new and modern layout of an area, it is obviously necessary for some person or authority to acquire ownership of all the lands in the area, to assemble all the separate lots, streets, and allowances for streets under the one ownership. Where individual lots are owned by private persons, whether they are built upon or are vacant (in this instance most of them were vacant), expropriation is an essential power, to be exercised with discretion of course, but essential to prevent one or more private owners refusing to sell his or their properties and thereby holding up or defeating a whole housing project development." ${ }^{3}$

Like the developers of Don Mills would do later, Manor Park Realty Ltd. established an overall plan for subdividing the assembled land, set the terms of reference for the buildout, and sold off parcels to various builders. ${ }^{4}$

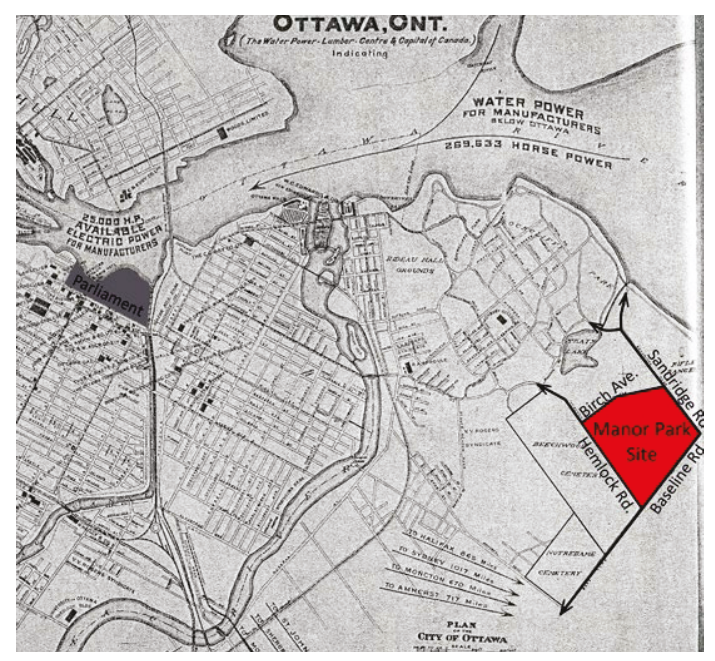

Figure 12: Map from 1911 locating Manor Park site in relation to existing roads 
Consistent with practices at the time, the municipality took responsibility for providing the services (water, sewers, etc.).

All of Manor Park's builders applied similar construction techniques. A September 1947 article on Manor Park in Canadian Homes and Gardens discusses the impact of the "Peerless system" on reducing construction costs. Under this system, materials are precut then assembled by specialized groups of labourers. In Manor Park, as in Levittown and Don Mills, the application of modern construction methods meant that the workers each became specialists in one aspect of the construction process. This division of labour, coupled with the use of standardized materials, enabled the developers to quickly provide large quantities of housing, contributing to its affordability. The article discusses the overall plan to build several hundred houses based on a limited number of plans, three of which were discussed at length. ${ }^{5}$ (Fig. 13 - 15) Designs tended to be variations on the government-issued war-time bungalow and were virtually identical to the Cape Cods that the Levitts were constructing on Long Island at the time. The simplicity of the house styles was intended to reduce the overall purchase price to make them affordable to young families with limited budgets. The Seymour Report notes, "In Ottawa, I would think that the initial selling price of certain projects ... the first two-hundred in Manor Park - was of the order of fifteen to twenty percent underneath the free market." 6 According to the Canadian Homes and Gardens article,

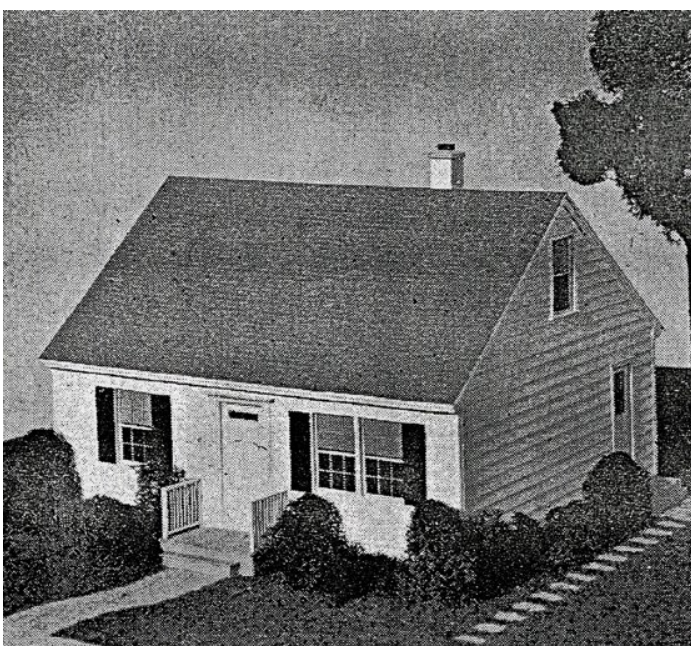

Figure 13: Architects rendering of Manor Park 'SemiBungalow` design

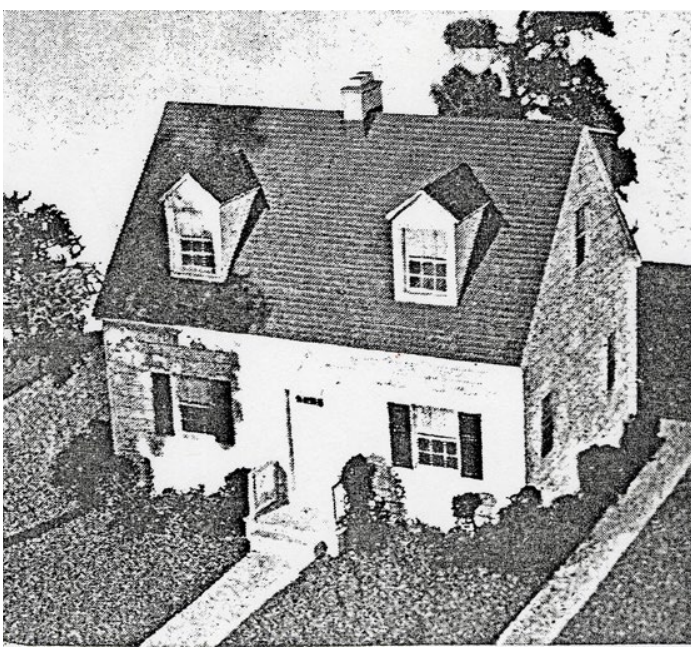

Figure 14: Architect's rendering of 'One-and-a-Half Storey Cape-Cod’ design

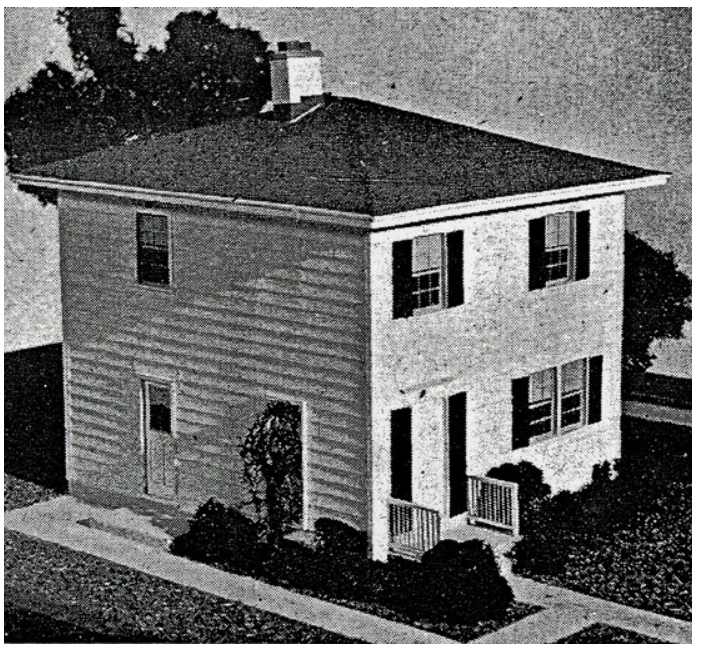

Figure 15: Architects rendering of Manor Park 'Two-Story Modernized Colonial' design 
purchasers could mortgage their homes over a 20 -year period, paying only $\$ 52$ a month for principal, interest, taxes and insurance after a down payment of about $25 \% .^{7}$ CMHC mortgage guidelines might have been able to further reduce mortgage costs by cutting the down payment to $10 \%{ }^{8}$

Across both design phases a variety of units were provided. According to Seymour, by 1953, "Some fourteen hundred housing units, ranging from single houses to bachelor suites in apartment buildings have been built since the spring of $1947 .^{\prime \prime}$ In addition to houses for purchase, the initial design plans for Manor Park included rental apartments, accommodating a variety of tenancy options. Rental units in Manor Park took two forms: apartment buildings to the east of St.
Laurent Blvd. (part of Phase 2), and terraces of row houses in an area now called Manor Park Estates (MPE) on the northwest corner of Hemlock and St. Laurent Blvd. Similar blocks of row houses were built later, further to the southeast, as Manor Park extended east of St. Laurent Blvd. As with Levittown, however, the economics of long-term mortgages made renting more expensive than purchasing. While single-family houses in Manor Park cost their owners $\$ 52$ a month, ${ }^{10}$ similarly sized units rented for $\$ 96$ a month. ${ }^{11}$ In this light, it is unusual that Manor Park not only integrated rental housing, but that it survived.

The original plans for Manor Park included a shopping center (Fig. 16). Here it is important to remember that, when it was developed,

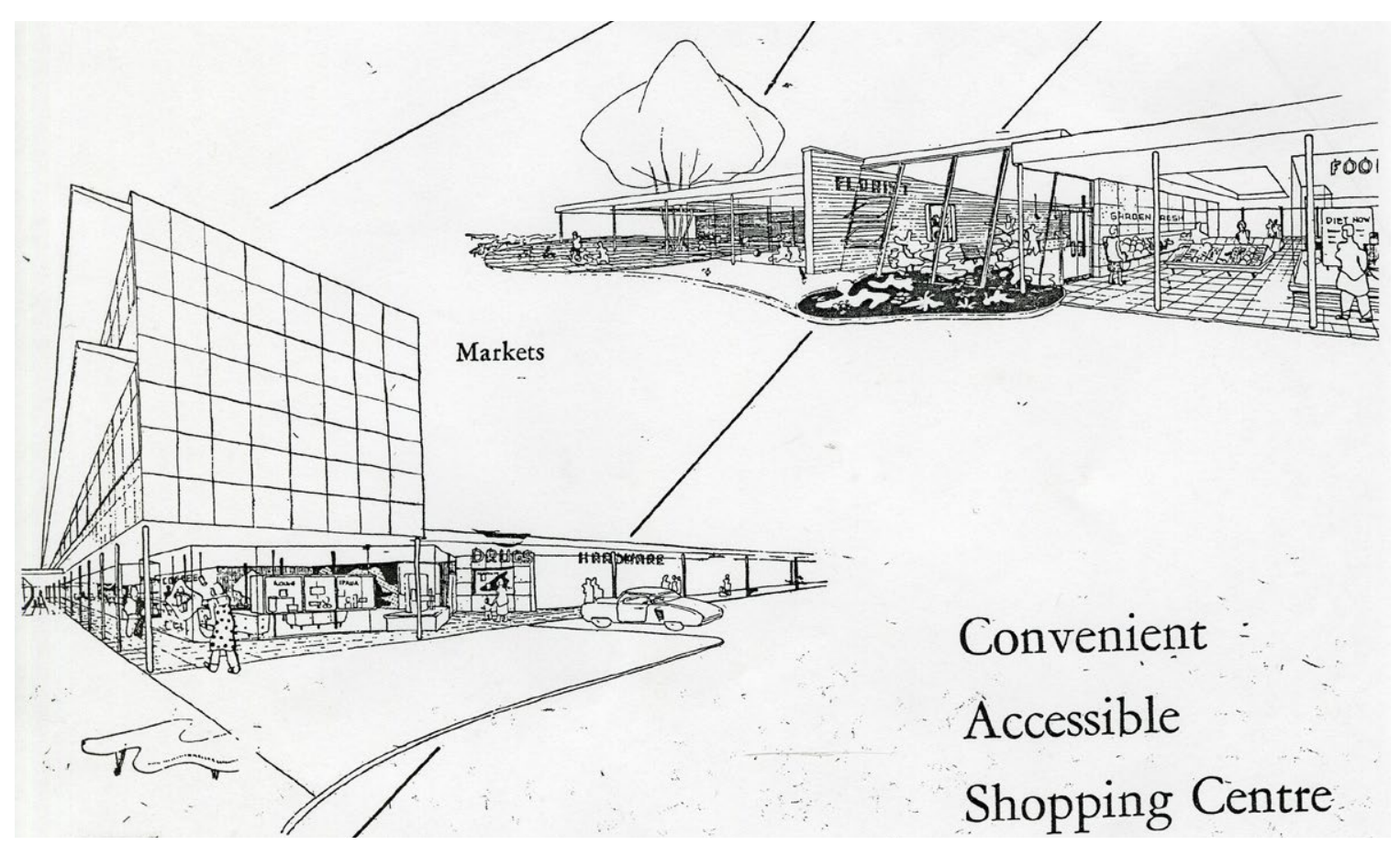

Figure 16: Architects rendering of Manor Park shopping center 
Manor Park was at the far periphery of the City of Ottawa and the services provided in a shopping center were key to drawing residents to the area. The shopping center was envisioned in a compact group or plaza, similar to what Carver recommended, strategically placed along St. Laurent Blvd. at the eastern edge of the neighbourhood. Surrounded by parking, the design of the shopping plaza reflects the dominance of the car for transportation. The need for parking likely explains why the shopping differs from the compact areas mixed with rental apartments included in Perry's diagram. Ultimately, however, this shopping plaza was never built.

In 1950, while construction on Phase 1 of Manor Park was underway, Manor Park Realty Ltd. requested that the City of Ottawa expropriate additional lands, this time on the East of St. Laurent Boulevard. The city again complied and Phase 2 extended the subdivision by about 120 acres. ${ }^{12}$ This extension was more constrained in shape than Phase 1. It was bounded to the north by an existing subdivision, to the east by the Royal Canadian Air Forces base (the former CFB Rockcliffe) and a proposed hospital site, by Montreal $\mathrm{Rd}$. to the south, and by the Beechwood and Notre-Dame cemeteries to the East. In terms of its plan, and in comparison to Perry's neighbourhood unit, Phase 2 of Manor Park was more of an ellipse than a circle. (Fig. 17)

Like Phase 1 , the $2^{\text {nd }}$ phase included $\sin$ gle-family dwellings, multi-unit dwellings and a shopping center. ${ }^{13}$ The latter - the multi-unit dwellings and shopping center were to be located where the two phases overlapped at the southeast corner of St. Laurent Blvd. and Hemlock Rd. This intersection was suited to higher densities and could have provided the levels of traffic required to support the proposed shops. While there is less information available on the exact form that the rental housing was to take, it is clear that the builders, Alvin Enterprises, intended to build affordable apartment buildings around the proposed shopping center. Phase 2 made no provision for a school, likely due to the fact that the elementary school in Phase 1 had been shifted toward Hemlock to be accessible to portions of the neighbourhood. This will be addressed in greater detail below.

\section{Manor Park as Built}

Phase 1 of Manor Park was constructed largely as planned. It adheres to the initial zoning plan with the various housing types and the school both having been constructed as proposed. The exceptions, however, are interesting and warrant discussion. As noted, the largest change in the build-out of Phase 1 relates to the parcels intended for shopping plazas along St. Laurent Boulevard- both of which were built out as multi-unit terrace houses similar to those on the northeast corner of Hemlock and St. Laurent Blvd. Seymour sums up the apparent reasons for the changes to the plan as follows,

"The developers having been 


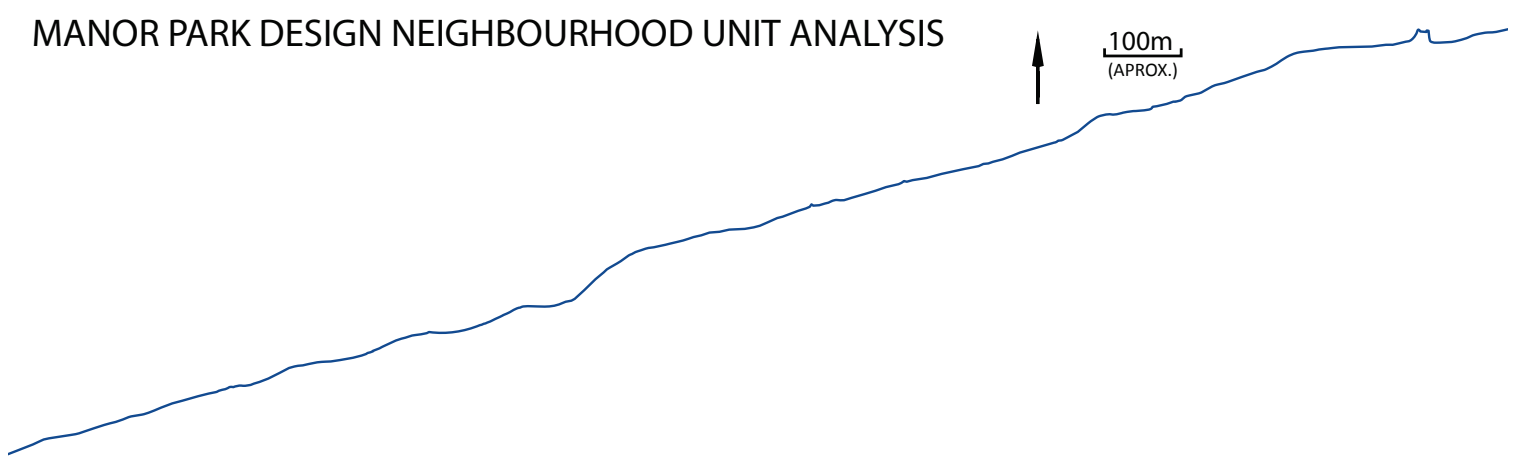

PHASE 1

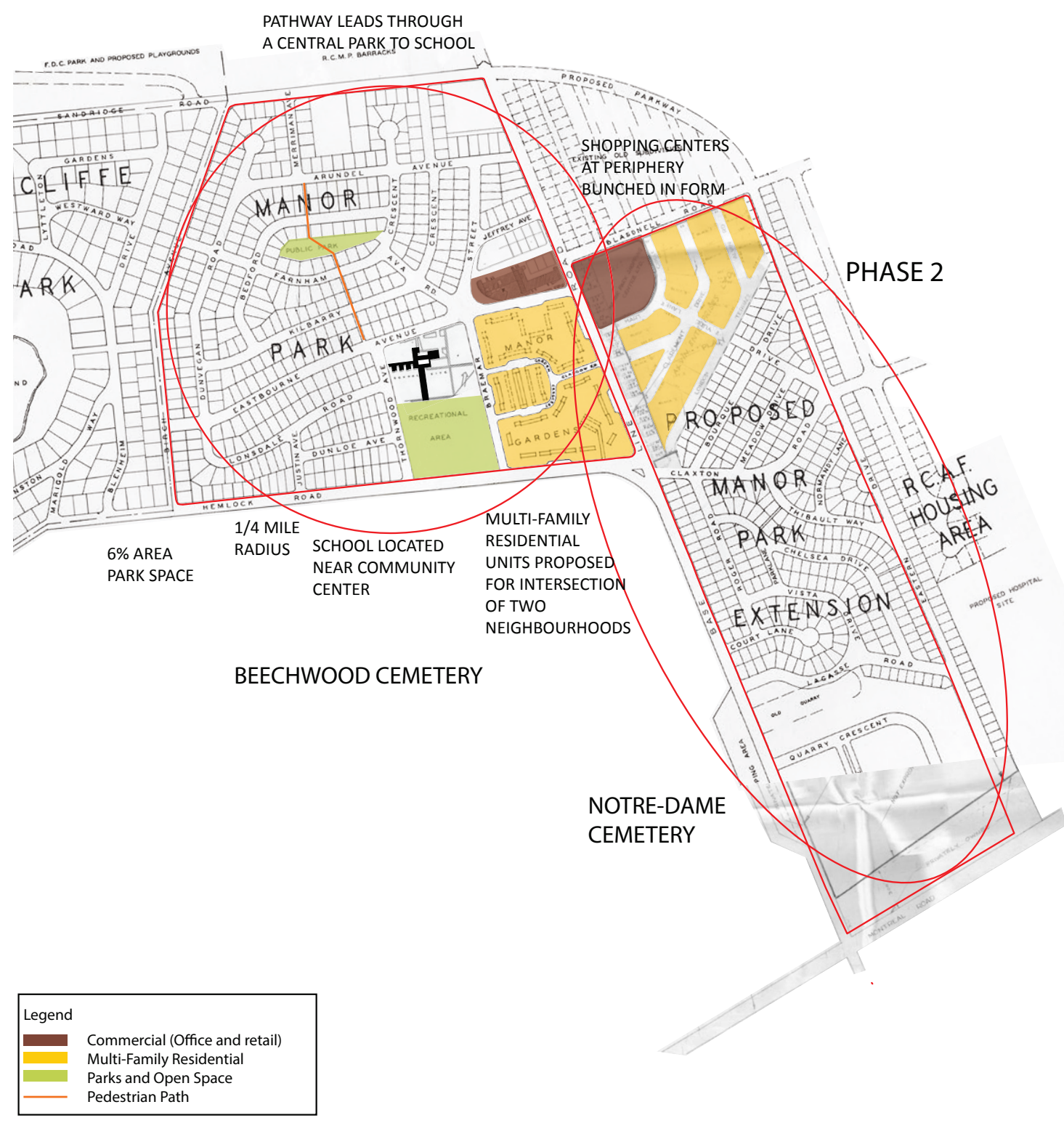

Figure 17: Plan analysis of Manor Park's design development, compiled by author from various sources 


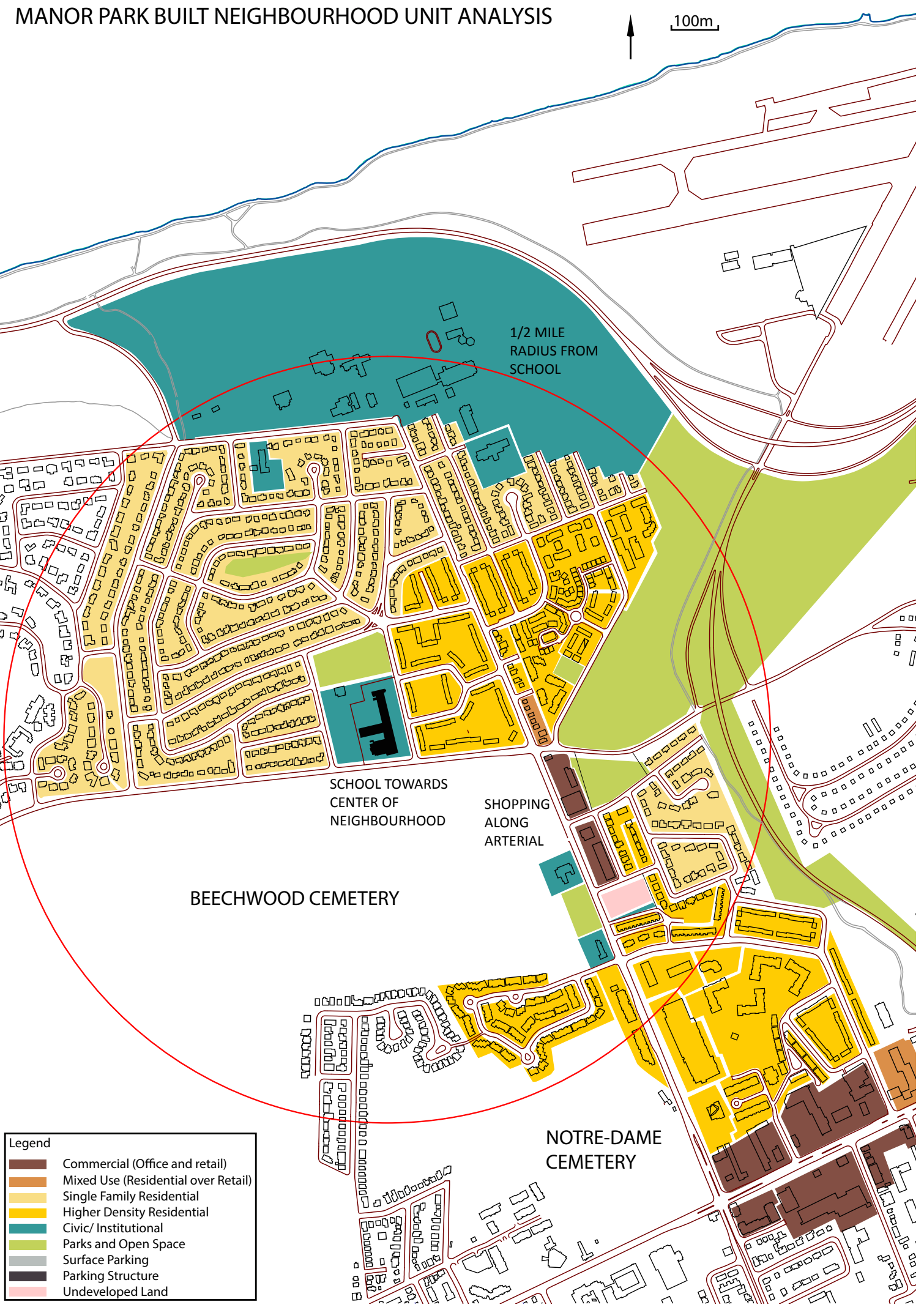

Figure 18: Analysis of Manor Park Neighbourhood as built 
approached by the owners of properties adjoining the proposed shopping center on the west side of St. Laurent, to change the plans and establish residential buildings of various kinds thereon, and apparently, having realized that the two proposed shopping centers were not together large enough for the whole area, decided to change their plans and establish a shopping center on the east side of St. Laurent, south of Hemlock and London Terrace." ${ }^{14}$

The change in location occurred around $1953,{ }^{15}$ resulting in the shopping plazas, on the southeast corner of St. Laurent and Hemlock. The new location accommodated more area for the shopping center and related parking, and also kept commercial activities away from more of the single-family residential areas.

A second change is apparent only upon close inspection of the plan published in Canadian Homes and Gardens, namely, the slight southward shift in the location of the elementary school. This decision to place the school closer to Hemlock likely occurred in the early 1950s following the decision to extend Manor Park. The modified location is more central with respect to the larger Manor Park subdivision (Phases 1 and 2) shown in figure 18.

While Phase 2 of Manor Park was constructed in the intended location, it included many fewer single-family dwellings than appear in the 1950 plan. This can be partly explained by the Department of National Defence's decision, in May of 1950, to expropriate a triangular area for a flight-way clearance for the nearby Rockcliffe airfield. ${ }^{16}$ This parcel has since remained vacant. The creation of a shopping plaza on the east side of St. Laurent Blvd. coupled with the establishment of Hemlock Park immediately behind it further decreased the area available for single family dwellings.

While not well documented, a further reduction in the number of single-family dwellings corresponds with the decision to build out the area along Brittany Dr. with terrace houses. These are of the same style as the rental units on the northwest corner of Hemlock and St. Laurent. Based on this one might conclude that rental units were indeed highly profitable. Fuelled by the strong demand for housing, Manor Park must have been desirable enough to attract families willing to pay the higher rates to rent.

The right-of-way for the parkway that appears in the 1950 plan for Manor Park was also changed prior to the construction of the Aviation Parkway in $1988 .{ }^{17}$ The initial design was likely a part of the eastern extremity of the 1951 Gréber Plan that proposed a network of interconnected parkways around Ottawa. Advertising materials for Manor Park promoted the future roadway as reducing the commute between the neighbourhood and downtown Ottawa. ${ }^{18}$ While, as constructed, the Aviation Parkway does form a part of a system of parkways, its connection to the Rockcliffe Parkway (along 
the river) was shifted further north and east.

Moreover both parkways were flanked by wide, park-like areas to keep residential development at a distance. This differs from the initial plans in which the Aviation Parkway is shown connecting directly into Manor Park's streets.

As constructed, Manor Park can be roughly described by a $3 / 4$ circle with a radius of a half mile (the same diameter as the neighbourhoods in Radburn). Within the larger plan (Phases 1 and 2), the school and shopping areas were both positioned near the center and along arterials so as to be easily accessible to a car-dependant population. The bulk of the rental housing is also located at the heart of the community, with easy bus access to downtown Ottawa.

\section{Manor Park Today}

While Manor Park has matured into a desirable, stable suburban neighbourhood within the greenbelt, there is ample evidence that the area is under development pressure. New projects in the area include a recently approved tower on St. Laurent, by Brigil, stacked townhouses in the LA Group Construction's Upper East Side project on London Terrace, Domicile's Kavanaugh condominium under construction on Beechwood, Minto's recently approved condo and commercial building at Beechwood and McKay, and the redevelopment of the decommissioned CFB Rockcliffe by Canada Lands Company (Fig. 19). The largest and most significant of these is CFB Rockcliffe - directly to the east of Manor Park on the opposite side of the Aviation Parkway - the

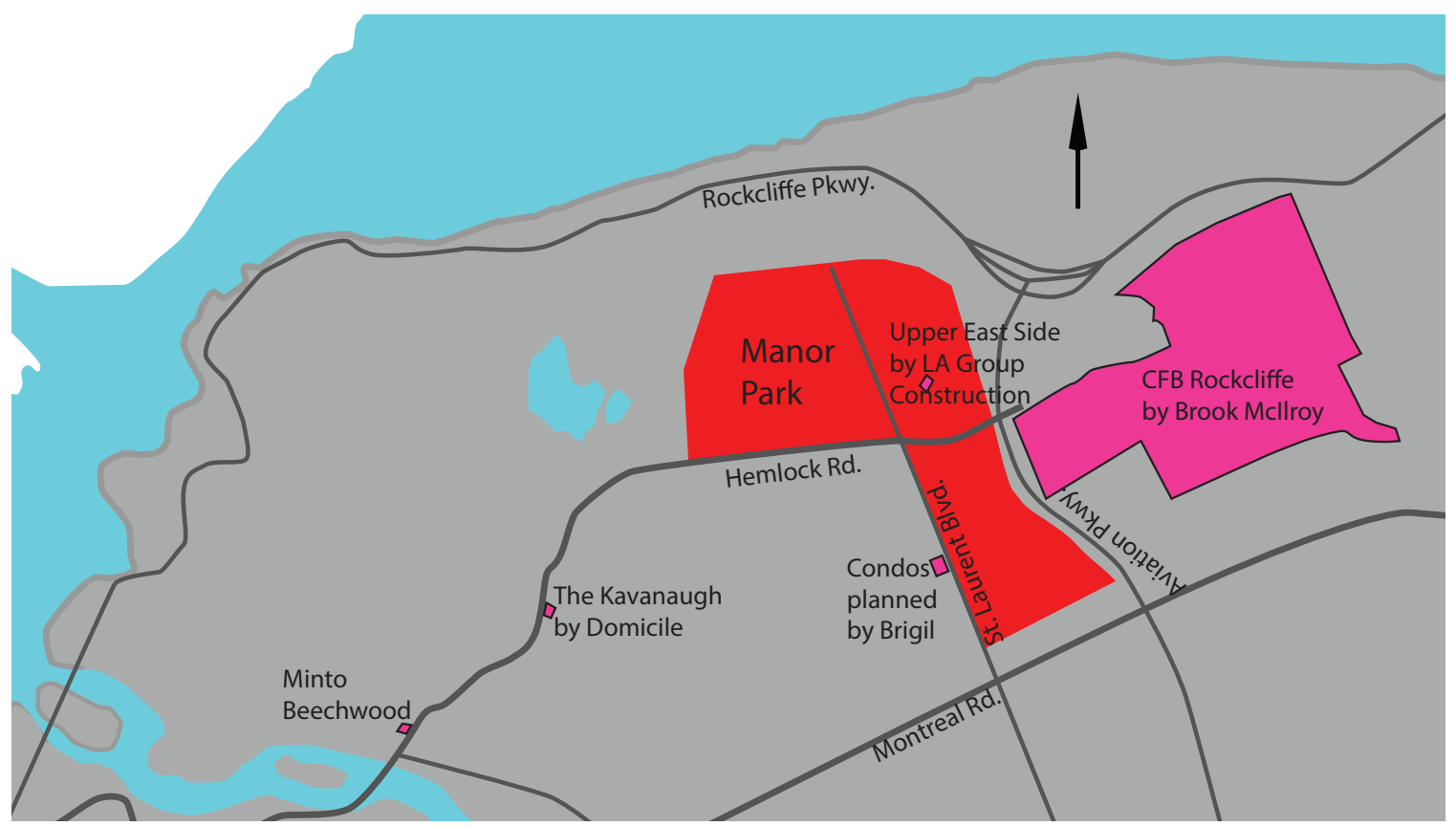

Figure 19: Recent and upcoming development projects in the Manor Park area 
master plan for which is being prepared by Brook Mcllroy in conjunction with the landscape architect Janet Rosenberg. Canada Lands Company, the current owner of the site, has set aggressive goals for a sustainable, mixed-use, community on the largely vacant site. ${ }^{19}$ CFB Rockcliffe sustainable features include: mixed land uses, multi-modal transportation (walking cycling, transit, cars), conservation of natural features, ${ }^{20}$ and green infrastructure ${ }^{21}$. At 310 acres, roughly the size of two of Perry's neighbourhood units, the former airbase will eventually accommodate about 6000 residents. ${ }^{22}$ The improvements to this large area, close to the urban core, will increase development pressure on Manor Park. If and when it is redeveloped, Manor Park Estates might be able to capitalize on the sustainable design marketing of CFB Rockcliffe, incorporating sustainable features into its own re-design.

As suburban intensification is likely to occur in Manor Park in the coming years, it is pertinent to evaluate the neighbourhood to determine where this intensification might occur and what form it might take. Ellen Dunham-Jones and June Williamson, authors of Retrofitting Suburbia, call attention to the "static" nature of single-family, residential areas, which are resistant to change due to zoning, or difficulties in assembling multiple lots. ${ }^{23}$ Meanwhile larger lots are ripe for intensification, especially since, "Internal integration of parts is far easier to control on single-parcel sites." ${ }^{24}$ As Manor Park Estates forms the largest low density, single-owner parcel within Manor Park, it will be the focus of the demonstration plan for the redevelopment of the neighbourhood. The size of the site and its strategic location coupled with the low density and relatively poor condition of the ageing terrace housing makes Manor Park Estates a prime target for redevelopment.

\section{Manor Park Estates}

Manor Park Estates (MPE), a "campus" of terrace housing within Ottawa's Manor Park neighbourhood, has evolved from a higher priced housing option, into an enclave of low-cost market rental units. The 23-acre complex of 342 terrace townhouses, now represents a substantial stock of family-friendly, affordable housing within a relatively upscale neighbourhood. Spanning five large lots, four of which are west and one of which is east of St. Laurent Blvd. As noted, initial designs for Manor Park called

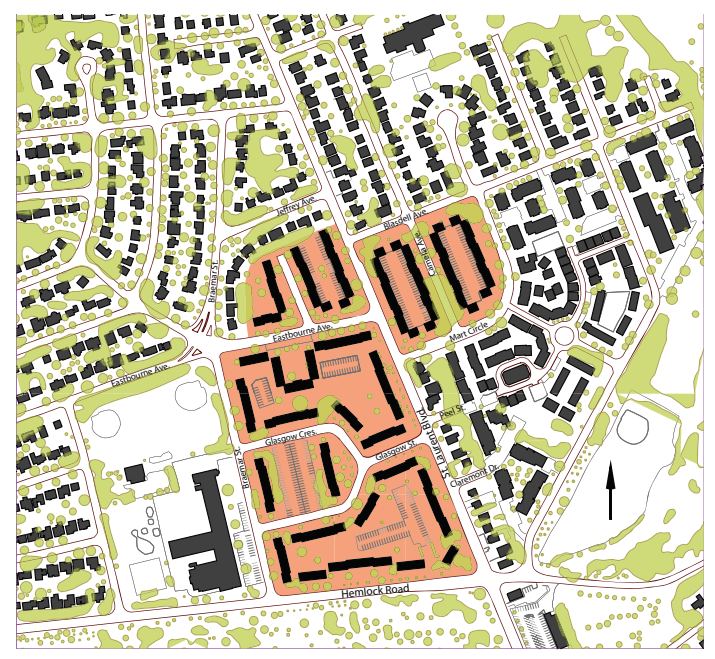

Figure 20: Manor Park Estates 
for rental housing on three of the five blocks, with the remaining two set aside for shopping centers.

Architecturally, the structures are modest blocks of two-storey brick row houses, set well back from the street (Fig. 21), through which multiple perforations lead to vast, communal spaces at the center of each block. While tenants were initially given the option of renting garages, these have since been demolished. It can be assumed that the inclusion of rental housing was meant to appeal to the majority of the population, who, prior to World War II, would have been renters. While promotional materials show units ranging from one to three bedrooms (Fig. 22) to suit a variety of family sizes, only two-bedroom units were constructed. This might be explained by a number of factors. First, the market consisted primarily of young couples whose space requirements would have been best addressed with two bedroom units,

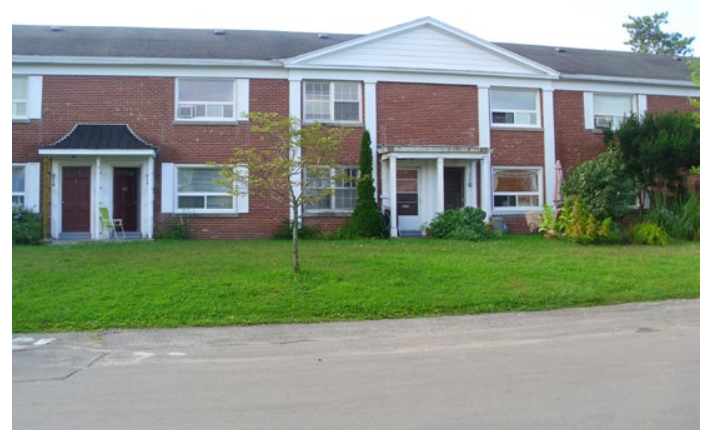

Figure 21: Photo of typical row houses in MPE and many of whom might have planned to move into adjacent (and more affordable) single-family dwellings as soon as they could assemble a down payment. Furthermore, two-bedroom units were more straightforward to construct as the one- and three-bedroom designs involved staggered party walls. Additionally, the larger units would not have been attractive to young families from a financial perspective, as the monthly rent was nearly double the monthly mortgage payments for similarly sized single-family homes in the neighbourhood.

As noted above, early residents of MPE would have been more affluent than surrounding homeowners. Those who chose to rent would have enjoyed the feeling of their own home, with the convenience of staff to maintain the property. As the neighbourhood has matured, however, the demographics have shifted. While the single-family dwellings have been updated and

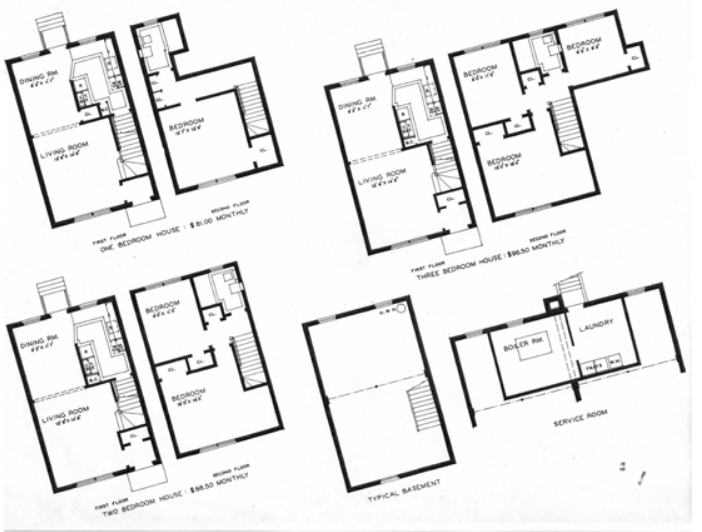

Figure 22: Unit plans of Manor Park Estates from 1950s promotional material 
frequently expanded, increasing their overall value, MPE has remained largely unchanged. The rents that these rental units are able to command has steadily decreased due to their age and the availability of other, newer rental options for those that can afford them. This phenomenon might be described as the process of residualization whereby the least desirable housing falls to those least able to afford it. Current tenants at MPE, likely of a lower demographic profile than their neighbours, are able to afford their unis because they are older and less desirable than equivalently sized newer units. Given their size, low density and direct access to grade, rental units at Manor Park Estate would likely not be affordable to current residents were they new.The terrace housing in MPE is over sixty years old; as such it will soon be in need of major lifecycle investments. ${ }^{25}$ Alternatively, the estate's owner Agarwal Sarinder, could opt to capitalize on the land value by starting afresh with a redevelopment that increases the site's overall density. Redevelopment is a particularly attractive option as the site is currently built out at only 15 UPA. Furthermore, increasing the density of MPE, coupled with the added density in CFB Rockcliffe, represents an opportunity to re-establish the mixed-use character initially planned for this portion of Manor Park. Such a mixeduse intensification project would provide an opportunity to readdress other aspects of the neighbourhood unit, breaking up blocks to increase connectivity and effecting a shift from an auto-centric development back to Perry's ideal of walkability. The following chapter will revisit Perry's neighbourhood unit in relation to current thinking on urban design, particularly as it relates to sustainability. This thinking, in turn, will form the basis for a demonstration project for the redevelopment of MPE that attempts to optimize the overall impact of design while protecting the character and social diversity of Manor Park as a whole.

\section{Notes}

1. Sewell, John. Houses and Homes; Housing for Canadians, James Lorimer \& Company, Publishers, Toronto, 1994, 90.

2. In 1950, Ottawa annexed 24,000 acres of land from both Nepean and Gloucester Townships, enabling the city to impose unified planning controls across the area. According to Thomas Nagy, in Ottawa in Maps; A Brief Cartographical History of Ottawa 1825-1973. National Map Collection., edited by Public Archives Canada. Ottawa: Information Canada, 1974.

3. Seymour, M. A. City of Ottawa Land Inquiry: Report of the Commissioner M.A. Seymour Esq. Q.C. Ottawa, 1953, 7-8.

4. Manor Park Realty Ltd. was formed by A. Warwick Beament K.C., R. Bruce Davis, C.C. Radcliffe, and K.J.G. Reene, and while they sold parcels of land to builders, namely Dennison Houses, Manor Park Shopping center Ltd., Manor Gardens Ltd. and Peerless Houses of Canada Ltd., these companies were all either represented by or owned in part by one of the members of Manor Park Realty Ltd. From: Summary of Submission to Commissioner by Charlotte Whitton 5. "Ontario's Newest Community Housing Plan." Canadian Homes \& Gardens (September, 1947): 2532.

6. Seymour, M. A. City of Ottawa Land Inquiry: Report of the Commissioner M.A. Seymour Esq. Q.C. Ottawa, 1953, 33.

7. "Ontario's Newest Community Housing Plan." Canadian Homes \& Gardens (September, 1947): 2532. 
8. Sewell, John. Houses and Homes; Housing for Canadians, James Lorimer \& Company, Publishers, Toronto, 1994, 85.

9. Seymour, M. A. City of Ottawa Land Inquiry: Report of the Commissioner M.A. Seymour Esq. Q.C. Ottawa, 1953, 4.

10. "Ontario's Newest Community Housing Plan." Canadian Homes \& Gardens (September, 1947): 2532.

11. Manor Gardens in Manor Park Village Ottawa; Canada's most Beautiful Garden Dwellings. Ottawa, Ontario: Manor Gardens Ltd., 1950.

12. Excerpt from the Minutes of the Board of Control of the Corporation of the City of Ottawa for August 15, 1950: Manor Park, Copies In Records filed with Commissionner, 1950, Acn 2010.0392.1 M01-07, City of Ottawa Archives, Accessed Oct., 2012.

13. "Manor Park Area Present and Proposed Development Plan." In Manor Gardens in Manor Park Village Ottawa; Canada's most Beautiful Garden Dwellings. Ottawa, Ontario: Manor Gardens Ltd., 1950.

14. Seymour, M. A. City of Ottawa Land Inquiry: Report of the Commissioner M.A. Seymour Esq. Q.C. Ottawa, 1953, 33.

15. Excerpt from the Minutes of the Board of Control of the Corporation of the City of Ottawa for April, 1953: Ottawa Expansion-Gloucester Annexation-Manor Park, Copies In Records filed with Commissionner, 1953, Acn 2010.0392.1 M01-07, City of Ottawa Archives, Accessed Oct., 2012.

16. Report:A.3(a)(a)(a) Re Amount paid for Flightway Lands, circa 1953, In Records filed with Commissionner, 1953, Acn 2010.0392.1 M01-07, City of Ottawa Archives, Accessed Oct., 2012.

17. Lishman, Judy. "The Tale of Manor Park Village; the 1950s." From the March, 1988 Manor Park Chronicle. http://www.manorpark.ca/printer/ neighbourhood/history/1950/(accessed March 20, 2013).

18. Manor Gardens in Manor Park Village Ottawa; Canada's most Beautiful Garden Dwellings. Ottawa, Ontario: Manor Gardens Ltd., 1950.

19. "Former CFB Rockcliffe Lands." Canada Lands Company. http://www.clc.ca/properties/ rockcliffe (accessed July 4, 2013).
20. "Presentation Boards- Public Open House 25/05/2013; Rockcliffe Community Design Plan." Canada Lands Company. http://www.clcrockcliffe.ca/ en/content/resource-library (accessed June 27, 2013), 9.

21. "Presentation Boards- Public Open House 25/05/2013; Rockcliffe Community Design Plan." Canada Lands Company. http://www.clcrockcliffe.ca/ en/content/resource-library (accessed June 27, 2013), 16.

22. Nash, Michelle. "Plans for Former Rockcliffe Air Base Shaping Up." Ottawa West News, June 6, 2013, sec. Business directory.

23. Dunham-Jones, Ellen and June Williamson. Retrofitting Suburbia; Urban Design Solutions for Redesigning Suburbs. Hoboken, New Jersey: John Wiley \& Sons, Inc., 2009, 53.

24. Dunham-Jones, Ellen and June Williamson. Retrofitting Suburbia; Urban Design Solutions for Redesigning Suburbs. Hoboken, New Jersey: John Wiley \& Sons, Inc., 2009, 5.

25. Lukez, Paul. Suburban Transformations. New York: Princeton Architectural Press, 2007, 36. 


\section{Chapter 3}

While suburban neighbourhoods have long been the objects of disdain, current criticisms have focused on their auto-centrism and the environmental impacts of sprawling, low-density, single-use developments. In his forward to Suburban Transformations, Anthony Flint writes, "The soaring cost, in financial and environmental terms, of inhabiting and navigating the suburbs has irrevocably changed the framework for analysing post-war settlement pattern[s]." ${ }^{1}$ Numerous scientific studies demonstrate the detrimental impacts of human behaviour on the global climate, and, in particular, the effects of ozone-depleting greenhouse gases from the combustion of fossil fuels for transportation and for the heating and cooling of buildings. Architects and urban planners will play a pivotal role in the move towards a more environmentally sustainable society inasmuch as it is estimated that the built environment accounts for approximately $50 \%$ of the global energy consumption. ${ }^{2}$ Additionally, the design of our neighbourhoods and cities has a major impact on the amount of vehicle travel required to accomplish daily tasks. ${ }^{3}$

Sustainability is a difficult concept to grasp as the term has been twisted to suit the goals of different groups. However, one of the first organizations to define sustainability was the World Commission on Environment and Development (WCED) in a 1987 report

\section{The Three Spheres of Sustainability}

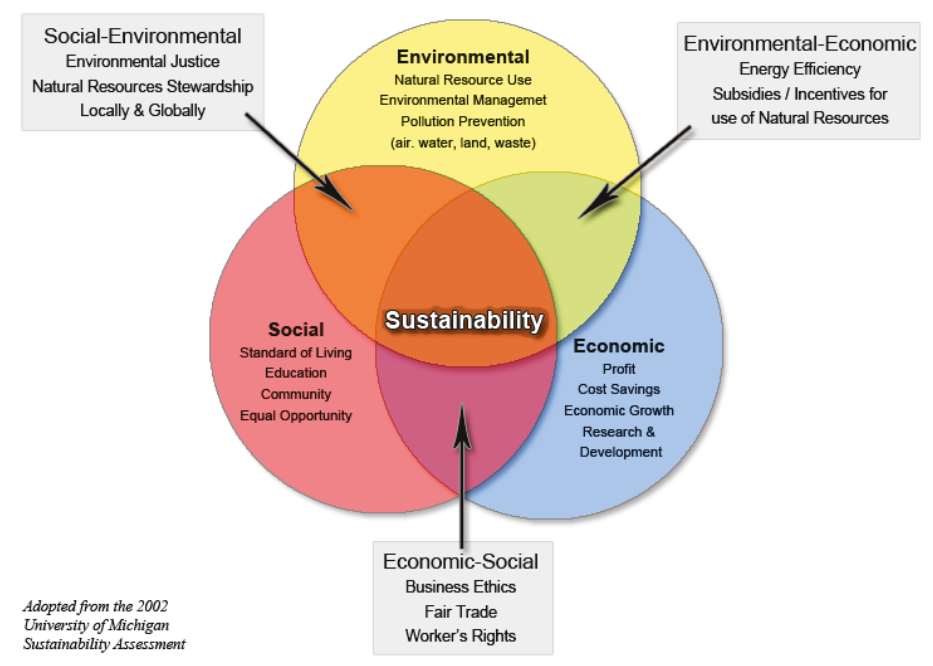

Figure 23: Triple-Bottom-Line diagram 
entitled Our Common Future (the so-called Brundtland Report). This report described sustainability as "The principle that economic growth can and should be managed so that natural resources are used in such a way that the quality of life of future generations is insured." While the concept of "quality of life" remains somewhat vague, the WCED linked economic growth, the management of natural resources and social wellbeing - or what is commonly referred to as the triple-bottom-line.' As demonstrated in figure $23,{ }^{5}$ the so-called triple bottom line is a way of taking into account the full costs - economic, environmental and social - of a project. Applied to an architectural or urban design project, this mode of thinking shifts the focus away from what is most economically advantageous in the short term towards optimizing the long-term impact of design.

As they can be challenging to measure, numerous rating systems have emerged to promote and facilitate sustainable building practices. One such rating system is the widely accepted LEED (Leadership in Energy and Environmental Design) program created by the U.S. Green Building Counsel (USGBC). Initially limited to new buildings, the LEED rating system was extended/adapted to neighbourhood design in 2009, with the publication of LEED 2009 ND. "The intent [of LEED ND] is to promote healthful, durable, affordable, and environmentally sound practices in [neighbourhood] design and construction." ${ }^{1}$ LEED ND combines green building techniques with the principles of $\mathrm{New}$ "[The founders of New Urbamism] united around a shared vision of promoting traditional urbanism as an antidote to conventional sprawl.".

\section{0 smart Growth Principles}

1. Create a range of housing opportunities and choices.

2. Create walkable neighbourhoods.

3. Encourage community and stakeholder collaboration.

4. Foster distinctive, attractive places with a sense of place.

5. Make development decisions predictable, fair and cost-effective.

6. Mix land uses.

7. Preserve open space, farmland, natural beauty, and critical environmental areas.

8. Provide a variety of transportation choices.

9. Strengthen and direct development toward existing communities.

10. Take advantage of compact building design.

Figure 24: Smart growth principles 
Urbanism and Smart Growth into a complete rating system for neighbourhood design. ${ }^{7}$

(Fig. 24) For the purposes of expediency, LEED ND has been chosen as the standard to which this thesis makes reference.

LEED ND was developed to help developers to create communities that reduce dependence on the car by permitting and encouraging the completion of daily tasks by walking or bicycling. An interconnected street grid combined with a mix of uses is ideal for achieving these goals. Additionally, it is important to integrate green infrastructure (environmental systems such as trees to reduce heat island effects and stormwater retention ponds to reduce runoff, etc.) along with energy-efficient buildings into neighbourhood design as, together, they can mitigate negative environmental impacts especially where resource consumption is concerned. The criteria put forward in LEED ND are meant to aid in the design of quality neighbourhoods that integrate a range of uses including residences, places of employment, civic uses and park spaces that, together, provide a high quality of life to the residents. ${ }^{9}$ As a rating system, LEED ND is organized into three categories addressing performance at different scales. They are: 1) Smart Location and Linkage, 2) Neighbourhood Pattern and Design, and 3) Green infrastructure and Buildings. Once the minimum requirements are met within each of these categories, a neighbourhood can be granted points for achieving design goals. Based on the total points earned, a variety of accreditation levels may be awarded.
In addition to being used to rate new neighbourhood designs, LEED ND can also be applied to neighbourhood retrofits. ${ }^{10}$ The opportunities and challenges associated with retrofitting suburban neighbourhoods has been the focus of such recent books as Retrofitting Suburbia; Urban Design Solutions for Redesigning Suburbs and Suburban Transformations. While suburban retrofits can take numerous forms depending on the existing conditions, the focus of development tends to be on densifying, diversifying and connecting large, single-use sites like shopping plazas into adjacent neighborhoods. The large asphalt parking lots associated with many such plazas have come to be known as 'greyfields.' Among other things, these sites represent capacity - a critical mass of land under single ownership on which to design mixed-used communities - although they often face zoning and regulatory challenges. To be successful, it is frequently necessary to significantly alter the existing zoning and design regulations of the entire area to provide a cohesive vision of what the neighbourhood might become. Propositions frequently draw on Clarence Perry's neighbourhood unit, particularly in terms of creating compact mixed-use areas, where walking is once again a viable option.

\section{The Neighbourhood Unit Revisited}

Perry's neighbourhood unit has been revisited at least twice in recent years. In both cases the proposed changes/improvements did not alter the fundamental structuring ideals. 
The first adaptation, made by Duany PlaterZyberk (DPZ) in 2002, interprets Perry's 1929 diagram (Fig. 25) as an urban neighbourhood. The neighbourhood's street grid is more interconnected than Perry's - which exhibits the garden-suburb era's preoccupation with cul-de-sacs and discontinuous streets ${ }^{11}$ and blocks are smaller. The neighbourhood streets in the DPZ version also align with other local streets, as compared with Perry's diagram where the streets have been offset relative to adjacent neighbourhoods. The primary school has been moved from the center to the edge of the neighbourhood to facilitate sharing with neighbourhoods close by. This change reflects demographic trends of declining family size, by acknowledging that a single neighbourhood is no longer likely to accommodate the population necessary to support an elementary school. Bordering arterials have been renamed boulevards and, while shopping is maintained at traffic intersections (this time in the form of shopping plazas), it also pushes into the neighbourhood along a mixed-use street. Local transit is introduced through a bus stop located at the center of the neighbourhood.

More recently, Perry's neighbourhood unit was adapted in 2008, by Douglass Farr, Leslie Oberholtzer and Christian Schaller (Farr Associates )(Fig. 26). In this version, more attention is paid to the natural environment, incorporating habitat corridors and infrastructure greenways as the boundaries to the neighbourhood. The Farr version respects the DPZ plan by maintaining the interconnected street grid and placing the school at the edge of the neighbourhood where it can be shared. The plan also incorporates high-performance infrastructure such as a district energy plant, dimmable streetlights and stormwater boulevards. ${ }^{12}$ Additionally, the plan emphasizes the inclusion of a range of housing types and mixed-use areas. True to Perry's diagram, the neighbourhood unit is limited to 160

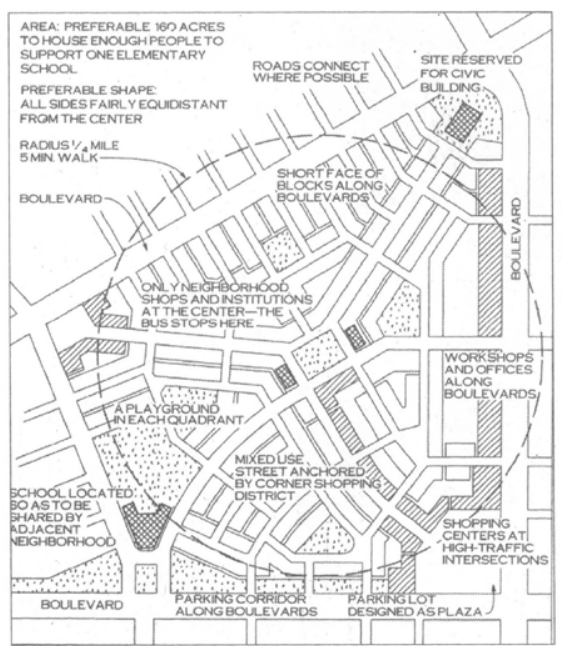

Figure 25: DPZ Neighbourhood Diagram

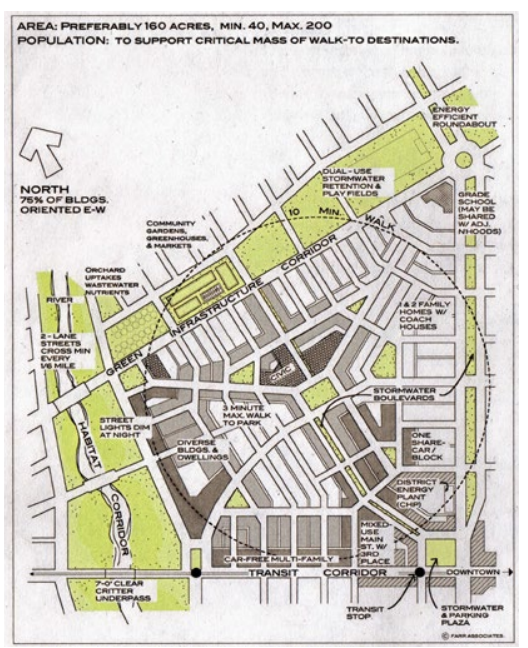

Figure 26: Farr Neighbourhood Diagram 
acres, enabling it to be traversed on foot in ten minutes.

Farr Associates also made a number of changes to reduce dependence on the private automobile. The focus of the neighbourhood unit has changed, in tandem with the change in demographics, from the elementary school to a mixed-used centre. Rather than sizing the population to support an elementary school, they've suggested the population should be sufficient to, "support a critical mass of walk-to destinations." Additionally, the Farr neighbourhood unit further emphasizes transit by creating a transit corridor along one edge, within easy reach of all areas of the neighbourhood. Two more changes directly reference the reduction in use of cars, namely, the inclusion of a car-share space on each block and carfree multi-family housing along the transit corridor.

\section{Precedents}

Recent projects have attempted to engage the issues addressed by DPZ and Farr Associates in their transformations of Perry's Neighbourhood Unit Diagram. These include increased connectivity, walkability and reduced environmental impacts as they apply to the renovation of existing suburban neighbourhoods. The communities of Mableton, Georgia and High Point (Seattle), Washington demonstrate different redevelopment focuses, while addressing the transformation of an existing suburb to be more sustainable in its own way. Among the few suburban retrofits that have been completed, most focus on the intensification of greyfield sites. Mapleton and High Point have been selected as case studies because of their approaches to dealing with other aspects of an existing suburban neighbourhood. The Mapleton design creates an interconnected, mixed-use community through a long-term design plan for the entire suburb. High Point addresses the integration of a large ensemble of rental housing into surrounding areas, while creating a mixed-income community and adding green infrastructure such as natural stormwater retention.

\section{Mableton}

Established as a stand-alone railroad suburb in the late 19th century, Mableton was, over time, absorbed into suburban Atlanta.

(Fig. 27) It exhibits many of the issues associated with suburban communities, notably segregated zoning, which, together with its

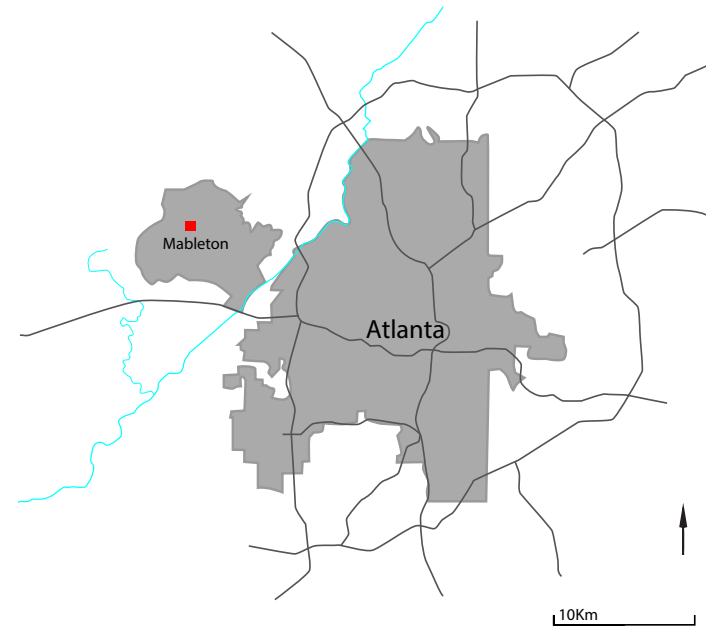

Figure 27: Diagram locating Mableton in relation to Atlanta 
superblock layout, creates a system that is heavily car-dependant (Fig. 28). ${ }^{13}$ In 2008, DPZ hosted a nine-day charrette that examined the challenges facing Atlanta suburbs and suggested ways of adapting these communities to better support an aging population. ${ }^{14}$ Following the charrette, the municipality of Cobb County retained DPZ to further develop a plan to lead Mableton into the future. DPZ's proposal included a roadmap for reconnecting the fabric and provided a "form-based code" tied to an "Illustrative Masterplan" (Fig. 30) to guide the buildout. ${ }^{15}$ While the overall area remains in the ownership of numerous individuals and entities, the plan provides a cohesive vision of a walkable, mixed-use community. As evident in Figure 27, DPZ recommended the introduction of numerous streets and alleys in support of a more densely connected street network. Along the modified streets, DPZ proposed the addition of a diversity of uses, from civic to single-family residential and mixed-use, resulting in an overall increase in density.

In tandem with the street modifications, the master plan for Mableton evokes the neighbourhood unit through the creation of multiple neighbourhood nodes that integrate multiple uses to produce a community where car-use is no longer a given. ${ }^{16} \mathrm{An}$ example of a proposed neighbourhood node is an area that currently serves as a community center, at the intersection of Floyd and Clay Roads (Fig. 31 - 32). Here, an indistinct collection of civic buildings, including a post

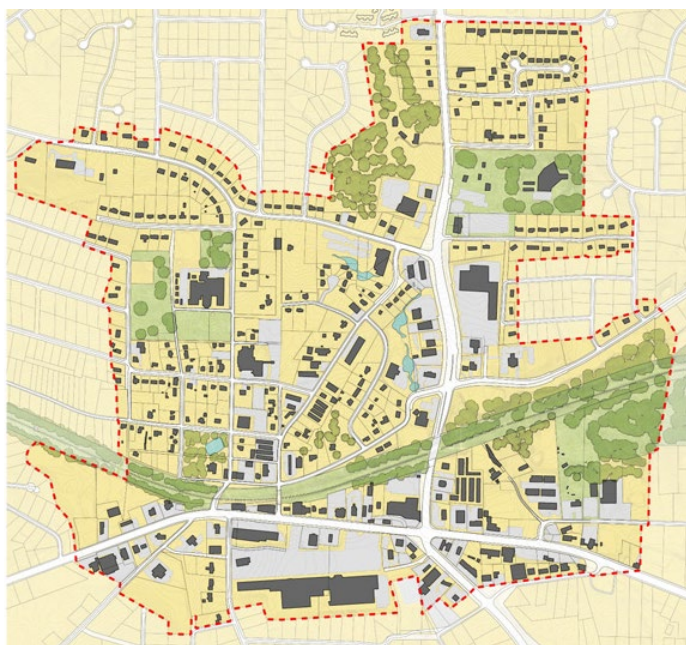

Figure 28: Plan of existing conditions in Mableton

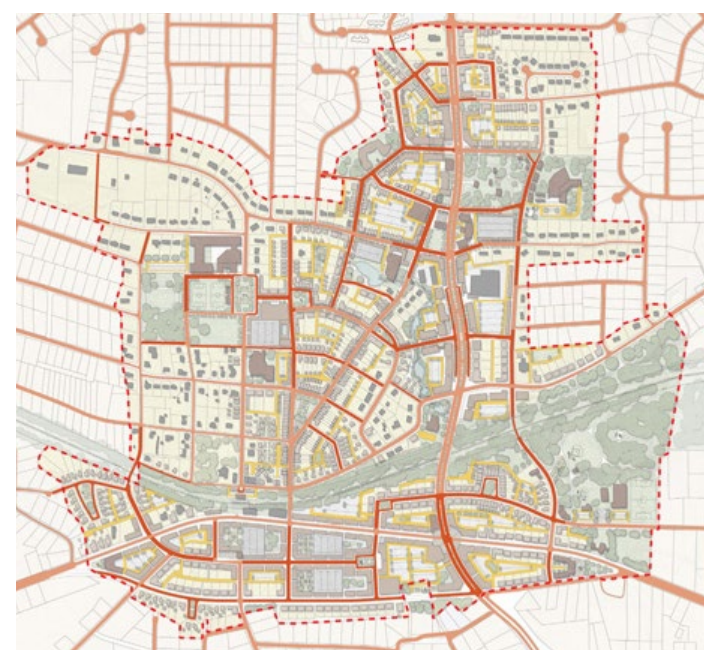

Figure 29: Plan of proposed streets for Mableton

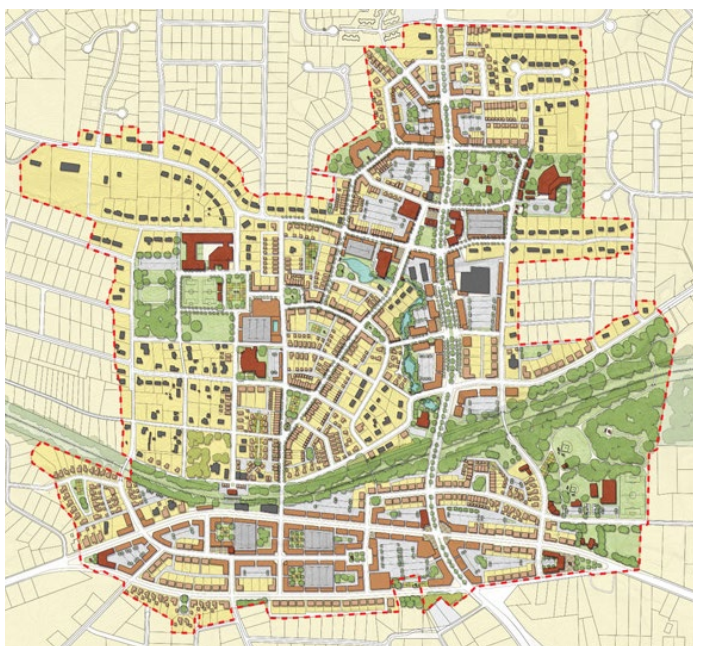

Figure 30: DPZ s Illustrative Masterplan of Mableton 
office, arts center, library, and amphitheater, will be linked through the creation of a central green by removing parking lots and infilling gaps between existing buildings with additional uses. The design of this area will be approached sensitively as "The redevelopment will need to shape an entire environment that reflects the place and character of Mableton as an important South Cobb regional destination." ${ }^{17}$

Another community node is slated for a 23.5acre parcel in northern Mableton. Known as the "Barnes homestead,"18 this is the area's largest private development site. Currently a greenfield, DPZ has proposed a new mainstreet, with commercial below and residential above, as well as both market-rate housing and seniors' housing. (Fig. 33) In addition to housing, the needs of seniors are further addressed by the inclusion of several new transit lines, including local and regional bus and train routes.

\section{High Point}

Constructed as war-worker housing in the 1940s, Seattle's High Point community (Fig. 34) was purchased by the Seattle Housing Authority for use as public housing in $1953 .{ }^{19}$ Although the ensemble (Fig. 35-36) provided affordable housing to thousands of residents for over sixty years, units had reached the end of their lifecycle and redevelopment became unavoidable. As the community was wholly owned by the Seattle Housing Authority, the redevelopment needed to address social as well as physical issues. The transformation

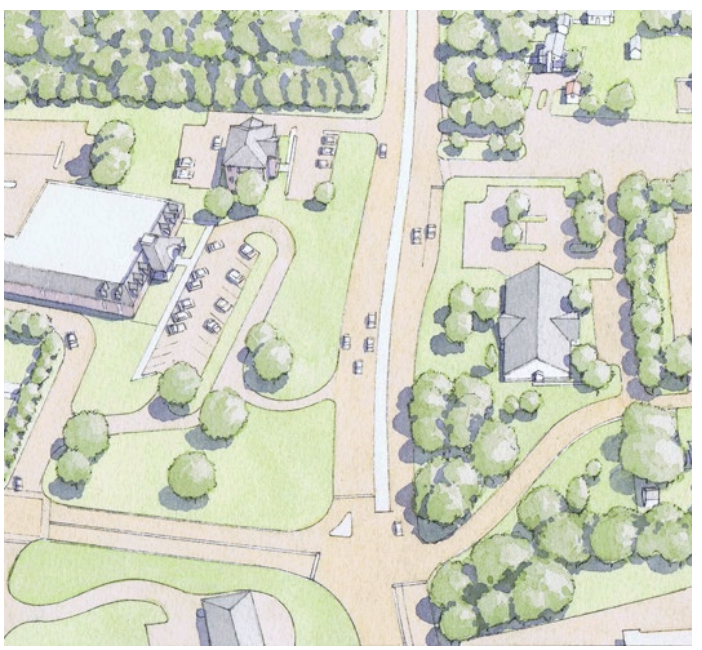

\section{Figure 31: Existing conditions at intersection of Floyd} and Clay

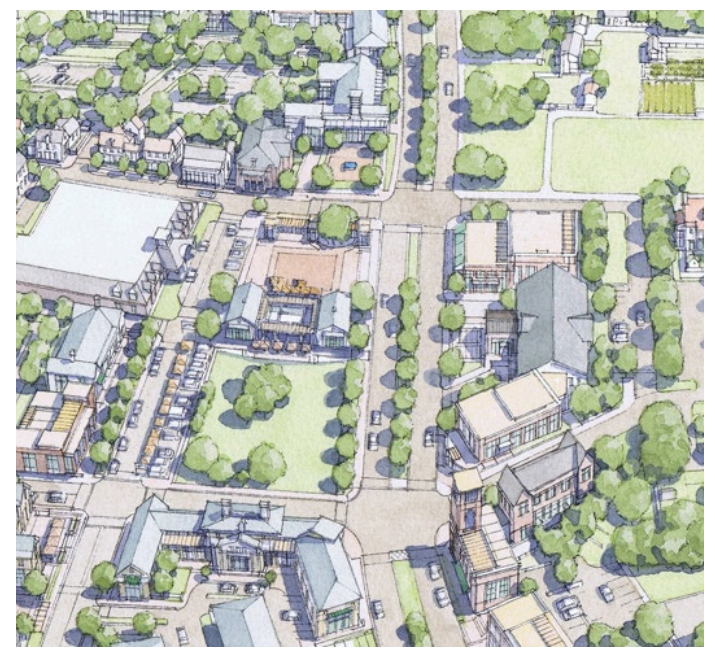

Figure 32: DPZ s vision for Floyd and Clay

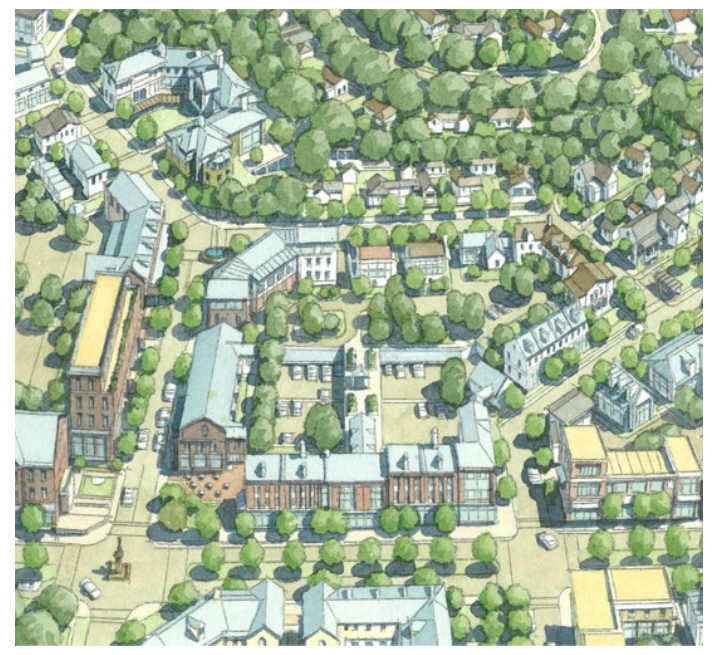

Figure 33: Community node at "Barnes Homestead" 
was kick-started when High Point was awarded a HOPE VI (Housing Opportunities for People Everywhere ${ }^{20}$ ) grant. ${ }^{21}$ Since its inception in 1996, the HOPE VI program has been used by the U.S. Department of Housing and Urban Development (HUD) to address public housing that, over time, had been "transformed into poverty traps characterized by high crime rates, significant unemployment, and deteriorating physical plants."22 Mixedincome neighbourhoods distinguish HOPE VI redevelopments, like High Point, from the so-called 'projects' they've replaced.

The goals of the High Point redevelopment included the creation of a walkable street grid, social integration through a variety of unit sizes and tenancy options, and sustainable development practices such as green buildings and natural, on-site stormwater management. Designed as an isolated, suburban, public housing complex, High Point was organized around a series of curving streets. (Fig. 37) In their redevelopment plan, Mithun Architects introduced a more regular grid that better integrated High Point with its surroundings. (Fig. 38) An additional benefit of the regularized street grid is that it reduces car dependence by increasing walkability. To further encourage walking, sidewalks were added and streets were lined with shade trees.

To accommodate a mix of income levels, the Seattle Housing Authority reduced the number of subsidized units available on site by adding units elsewhere in the city and

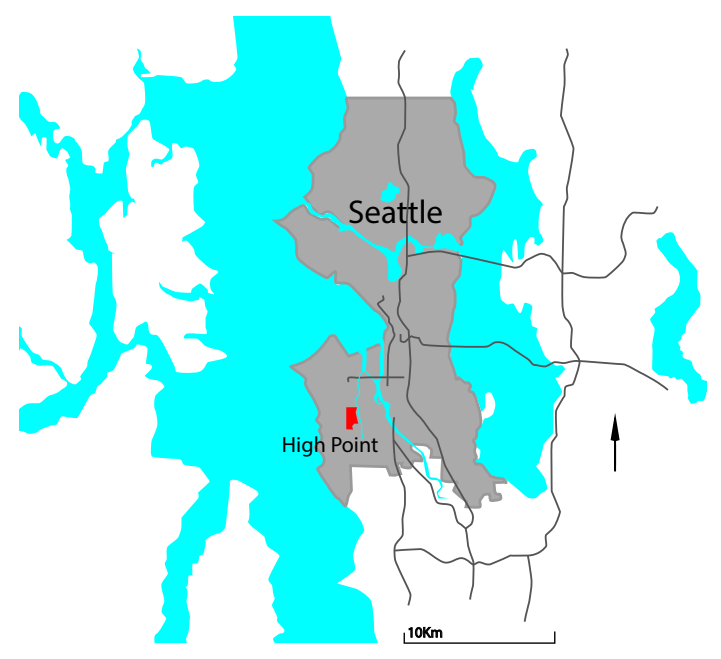

Figure 34: Diagram locating High Point in Seattle

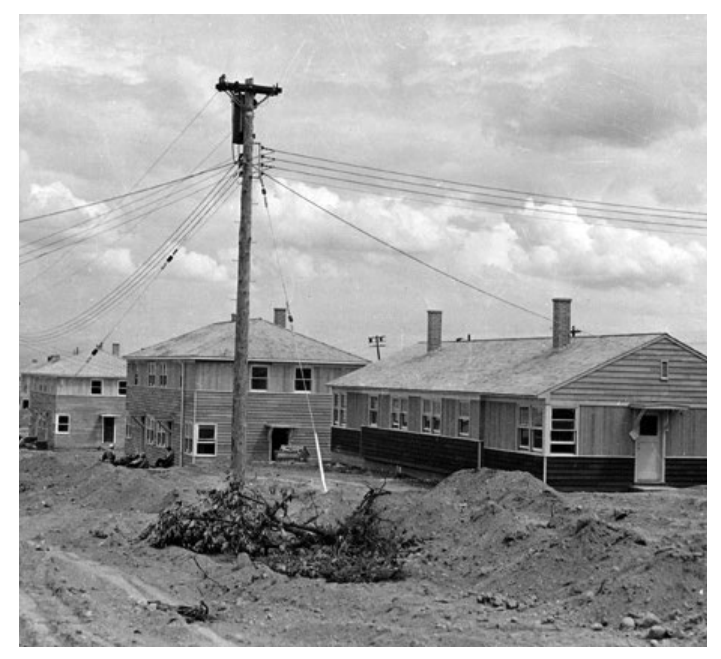

Figure 35: Photograph of High Point under construction showing housing forms

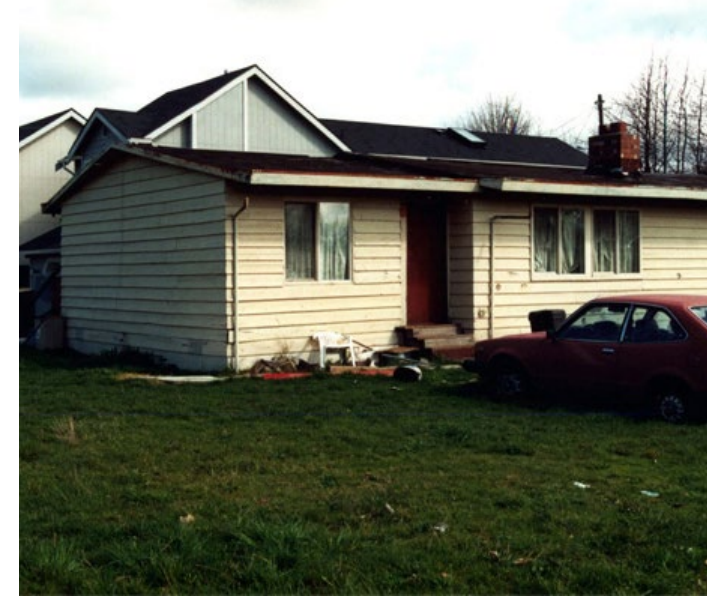

Figure 36: Photograph of High Point before demolotion 
providing some tenants with housing vouchers. ${ }^{23}$ The reduction in the number of on-site public housing units created space for market dwellings (Fig. 39), dispersed through the neighbourhood, with the net effect of an increase in total units. All of the replacement housing at High Point was built to Build Green standards, ${ }^{24}$ yet another rating system for energy efficient construction.

In addition to creating quality buildings, the design of High Point focused on reducing stormwater runoff to the nearby Longfellow Creek by incorporating a number of natural retention features. ${ }^{25}$ Bio-swales line neighbourhood streets to collect stormwater during rain events. These swales, seen in section in figure 38 , are essentially indentations in the earth planted with grasses and trees and under which a perforated drain directs the water to a retention pond enabling natural retention and filtration of much of the site's rainwater. Not only has the implementation of this natural stormwater retention system reduced the runoff to the creek by 65 percent, ${ }^{26}$ but it has reduced the burden placed on the city's stormwater system, during rain events. As we've seen, the neighbourhood unit, which formed the basic organizing principles for post-war suburbs, is still relevant today. With a few adaptations, such as those proposed by DPZ or Farr Associates, a suburban neighbourhood such as Manor Park could be revamped to better accommodate present and future residents in a more sustainable manner. The following chapter will draw on the adapted neighbourhood

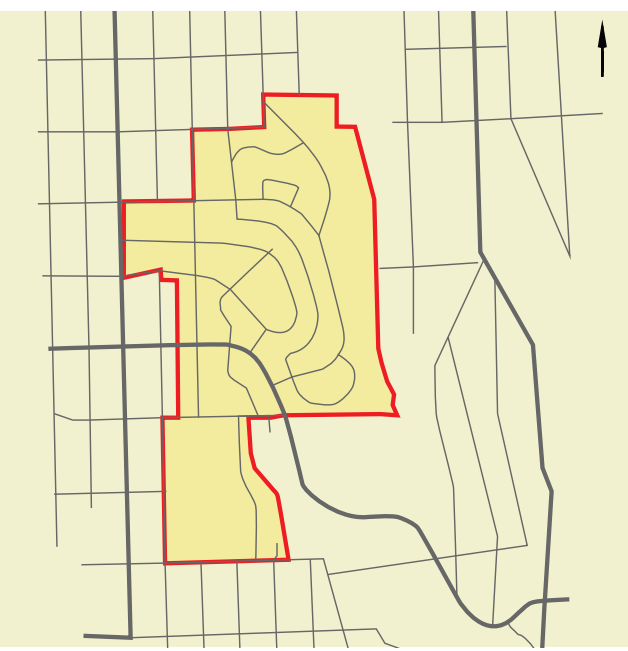

Figure 37: Historic street plan in High Point

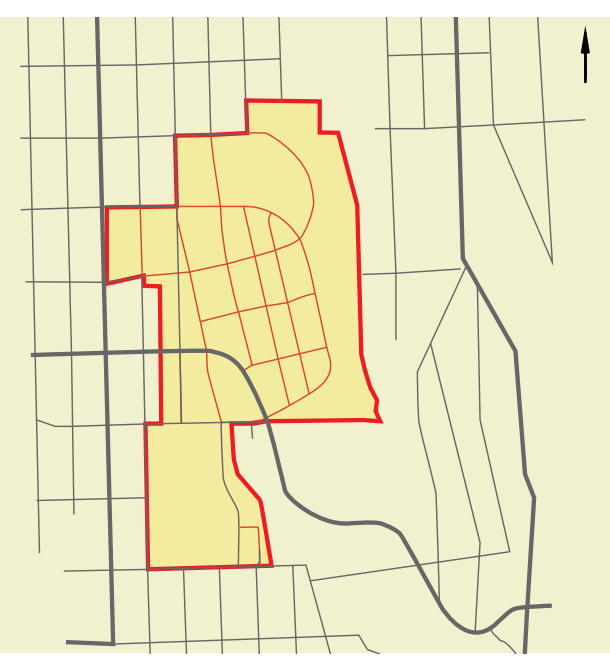

Figure 38: Modified street plan in High Point

\begin{tabular}{|l|l|l|}
\hline Housing type & $\begin{array}{l}\text { Income } \\
\text { Category }\end{array}$ & Units \\
\hline $\begin{array}{l}\text { For-sale } \\
\text { housing }\end{array}$ & Market rate & 790 \\
\hline Public housing & Very low income & 350 \\
\hline $\begin{array}{l}\text { Affordable } \\
\text { rental housing }\end{array}$ & Low income & 250 \\
\hline Senior housing & Market rate & 160 \\
\hline Senior housing & Very low income & 75 \\
\hline $\begin{array}{l}\text { Affordable for- } \\
\text { sale housing }\end{array}$ & Low income & 56 \\
\hline Units of on-site housing & 1,681 \\
\hline
\end{tabular}

Figure 39: Table showing breakdown of unit types at High point from http://www.seattlehousing.org 


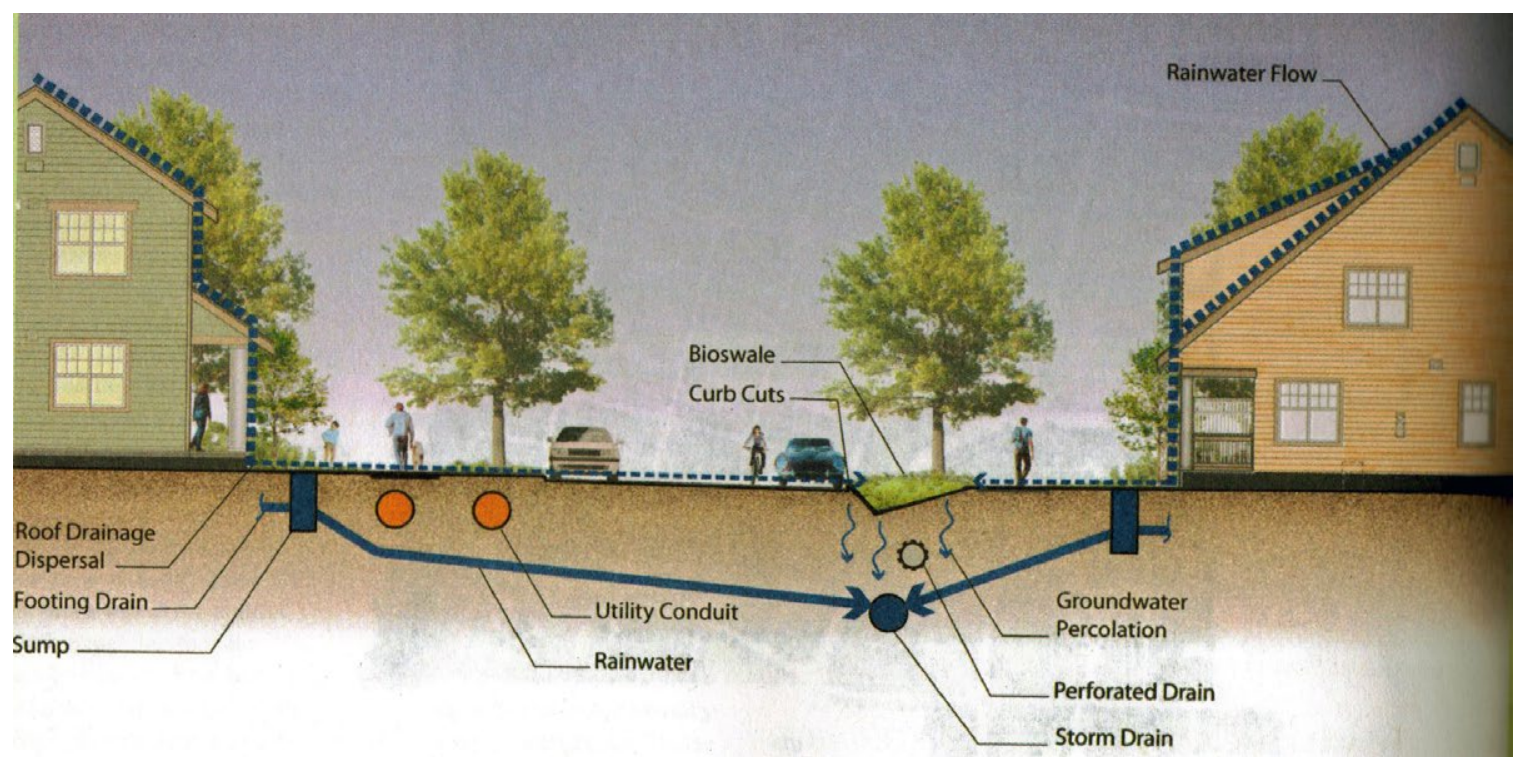

Figure 40: Street section showing High Point bioswales

diagrams, LEED ND and the redevelopment of Mableton and High Point to propose a demonstration plan for the transformation of Ottawa's Manor Park.

\section{Notes}

1. Flint, Anthony. "Foreword." In Suburban Transformations. New York: Princeton Architectural Press, 2007, 9.

2. Steel, James. Sustainable Architecture; Principles, Paradigms, and Case Studies. New York: McGraw Hill, 1997, 13-16.

3. Congress for the New Urbanism, Natural Resources Defense Council, and The U.S. Green Building Council. LEED 2009 for Neighbourhood Development. Online Pdf., 2012, xi.

4. Steel. Sustainable Architecture, 4-5.

5. "The Three Sheres of Sustainability." http://www. vanderbilt.edu/sustainvu/cms/files/sustainability spheres.png (accessed Aug. 7, 2013).

6. Congress for the New Urbanism et al. LEED 2009 for Neighbourhood Development, xiv.

7. Farr, Douglas. Sustainable Urbanism; Urban Design with Nature. Hoboken, New Jersey: John Wiley \& Sons, Inc, 2008, 28.
8. Ibid., 30.

9. "LEED for Neighbourhood Development." U.S. Green Building Council. https://new.usgbc.org/leed/ rating-systems/neighborhoods (accessed Nov. 6, 2012).

10. Congress for the New Urbanism et al. LEED 2009 for Neighbourhood Development, xv.

11. See Raymond Unwin's famous 1912 pamphlet, Nothing Gained by Overcrowding!.

12. Farr. Sustainable Urbanism, 126.

13. "Duany Plater-Zyberk and Company; Mableton, Georgia, USA." Duany Plater-Zyberk. http://www.dpz. com/Practice/1003 (accessed May 18, 2013).

14. "Duany Plater-Zyberk and Company; ARC Lifelong Communities." Duany PlaterZyberk and Company. http://www.dpz.com/ Practice/0821 (accessed May 18, 2013).

15. "Duany Plater-Zyberk and Company." Duany Plater-Zyberk. http://www.dpz.com/Practice/1003 (accessed May 18, 2013).

16. Ball Scott, M. "Masters Plan for Mableton." Architecture Week; Design and Building in Depth (Aug. 29, 2012), http://www.architectureweek. com/2012/0829/index.html (accessed July 3, 2013).

17. Ibid.

18. Ibid. 
19. "[High Point] Photos." Seattle Housing Authority. http://www.seattlehousing.org/redevelopment/highpoint/photos/ (accessed June 7, 2013).

20. Cisneros, Henry G. and Lora Engdahl, eds. From Despair to Hope: Hope VI and the New Promise of Public Housing in America's Cities. Washington, D.C.: Brookings Institution Press, 2009, 4.

21. "[High Point] Redevelopment Plan." Seattle Housing Authority. http://www.seattlehousing.org/ redevelopment/high-point/plan/ (accessed June 5, 2013).

22. Schmoke, Kurt L. "Foreward." In From Despair to Hope: Hope $\mathrm{VI}$ and the New Promise of Public Housing in America's Cities, edited by Henry G. Cisneros and Lora Engdahl. Washington, D.C.: Brookings Institution Press, 2009, vii.

23. "[High Point] Replacement Housing." Seattle Housing Authority. http://www.seattlehousing.org/ redevelopment/high-point/replacement/ (accessed June 5,2013$)$.

24. "Mithun; Restoring a Community." Mithun, Inc. http://mithun.com/knowledge/article/restoring community the high point story/ (accessed June 5, 2013).

25. Farr, Douglas. Sustainable Urbanism; Urban Design with Nature. Hoboken, New Jersey: John Wiley \& Sons, Inc, 2008, 234.

26. Ibid. 


\section{Chapter 4 Demonstration Plan}

\section{Introduction}

Reinforcing Carver's assertion that good housing involves not only appropriate house plans but the arrangement of the community as a whole, ${ }^{1}$ Perry's neighbourhood unit was brought to bear on the design of many post-war suburbs. As they've evolved over time, these suburbs have met with varied levels of success. Six decades later, it is prudent to consider how these neighbourhoods might be called on to continue to adapt in order to suit new demographic trends, lifestyle choices, and retailing patterns. Drawing on content covered in previous chapters this chapter explores a demonstration plan for the redevelopment of Manor Park Estates. While specific to and respectful of the character of Manor Park, a parallel goal is to identify strategies and recommendations that might be applied to the intensification of other, low-density suburban sites.

Having worked through a number of alternatives, the plan chosen for further development (Fig. 78) seemed both to be the most reasonable and the best "fit" for the site. Having settled on a new block and street organization, I went on to explore building massing and the distribution of uses, tweaking the plan in the process. At a finer scale, I've also explored numerous housing types, circulation routes, block organizations and strategies for managing stormwater. In addition to drawing on LEED-ND standards and precedents, an iterative design process was used to arrive at targets for density, floor space index (FSI), breakdown of unit types, and the ratio of residential to non-residential uses, etc., understanding the need to be both prescriptive and flexible.

\section{Issues at Play}

Driving the demonstration plan were provincial and municipal guidelines concerning intensification. Following Provincial policy, ${ }^{2}$ the Ottawa Official Plan has set aggressive goals for intensification. The Plan states that "About 90 per cent of the growth in population, jobs and housing will be accommodated within areas designated within the urban boundary." ${ }^{3}$ In line with other municipalities, the City of Ottawa believes it can provide services and facilities more effectively through intensification, rather than extending infrastructure into areas not already serviced. Additionally, as has been illustrated through the Farr neighbourhood unit, compact development reduces the impact of the built environment on natural areas and makes multi-modal transportation more feasible. 
The mixing of uses is key to encouraging modes of transportation other than the car. This is recognized by LEED ND as well as by the DPZ and Farr neighbourhood units. Compact, mix-used development reduces the amount of travel required to move between home, school, work, shopping and leisure activities, increasing the likelihood that residents will walk or bicycle for daily trips. Residential intensification can enable suburbs such as Manor Park to support a greater mix of uses such as office, small-scale retail, day-cares, etc., all of which benefit from population density.

The ability to choose transportation other than the private automobile to reach various destinations represents an improvement over current automobile-centric suburban patterns. In conjunction with intensification, circulation routes can be conceived as "complete streets," i.e., streets designed to integrate transit, pedestrians, bicyclists and automobiles equally. ${ }^{4}$ Complete streets are a sustainable option as they reduce both the number and distance of vehicle trips. Moreover, "the link between Complete Streets and public health is well documented." ${ }^{5}$

Reducing dependence on the automobile also increases the equitability and accessibility of the community to people of all age groups, notably children and the elderly. Manor Park is fortunate to be served by at least two city bus routes (\#7 \& \#5). While many suburbs cannot support transit due to their low densities, Manor Park has benefitted from direct bus connections to downtown Ottawa since its inception. As the City of Ottawa has committed to giving "priority to public transit in meeting future growth in travel demand," ${ }^{\prime}$ transit connections through the area are likely to increase in tandem with densities. That said, additional transit for this area is not a priority for the City of Ottawa, focussed as it is on so-called 'transit-oriented development' at nodes along the city's transitway. ${ }^{7}$ Multi-modal streets are referenced in Ottawa's Official Plan as part of the reasoning for dense development. ${ }^{8}$ Given the prospects for intensification, and considering that the area is already served by transit, Manor Park could easily incorporate 'complete streets.'

Adjacent developments, in particular that of CFB Rockcliffe, will also have an impact on the evolving form of Manor Park. Under the aegis of the Canada Lands Company, CFB Rockcliffe is undergoing a community design process intended to provide a "framework for creating a vibrant, mixed-used, sustainable neighbourhood." 9 The redeveloped airbase will eventually support some 6000 residents ${ }^{10}$ with a complement of commercial space. The sustainable features to be integrated into CFB Rockcliffe will raise expectations for adjacent development, including any in Manor Park.

In addition to sustainability, redevelopment within Manor Park will have to respond to Canadian demographic trends . While 
Manor Park was designed for young, growing families, the City's Official Plan observes that:

"As the children of baby-boomers leave home and form their own households, both parents and children will live in smaller households. In addition, the aging of the population is creating more seniors' households. Thus, much of the demand for new housing after 2006 is expected to be for smaller units, such as apartments." 11

Depending on how they are designed, condominiums can suit the needs of households without small children. While the condo designation did not exist when Manor Park was constructed, condominiums could be integrated as one of several multi-unit housing types to complement the existing housing and tenancy options.

Sensitivity to the existing, historic, character of Manor Park is key to the incorporation of new forms of housing. As an important early post-war suburb, the area's history and character must be recognized and respected. Meanwhile, as a vibrant, active neighbourhood, Manor Park should be allowed to evolve. Ottawa's Official Plan requires intensification projects to "enhance and build upon desirable established patterns and built form."12 Intensification of Manor Park should respect and enhance the existing character created so long ago by the neighborhood's Cape Cods.

The neighbourhood unit diagram can be deployed to negotiate the range of the issues at play in the possible redevelopment of Manor Park, particularly as revisited by DPZ and Farr Associates. In part based on Perry's neighbourhood unit, Manor Park could easily be adapted to support a mix of uses and modes of transportation suited to both current and future residents. These themes will be addressed in conjunction with other sustainable features such as connectivity, drawing on LEED ND and the precedents discussed in Chapter 3.

\section{Defining the Project}

Manor Park was selected for this study for a number of reasons. First, as previously mentioned, it was designed in the immediate post-war period as a prototypical suburban neighbourhood. As such, it is emblematic of post-war Canadian suburbs. Like other early automobile suburbs, Manor Park has been encircled by newer developments within and beyond the greenbelt. Given its central location, it is poised to transform. As such, Manor Park can once again serve as a prototype, this time for suburban intensification.

Additionally, Manor Park contains a number of sites that are well suited to redevelopment. Given the expense and logistics associated with land assembly, large lots are more likely to redevelop than blocks of individual, single-family houses. As indicated in figure 41, Manor Park includes several of these large, single-owner parcels. ${ }^{13}$ Figure 41 also indicates sites that are zoned to accommodate more than what currently exists, such as the RCMP lands to the north and the 


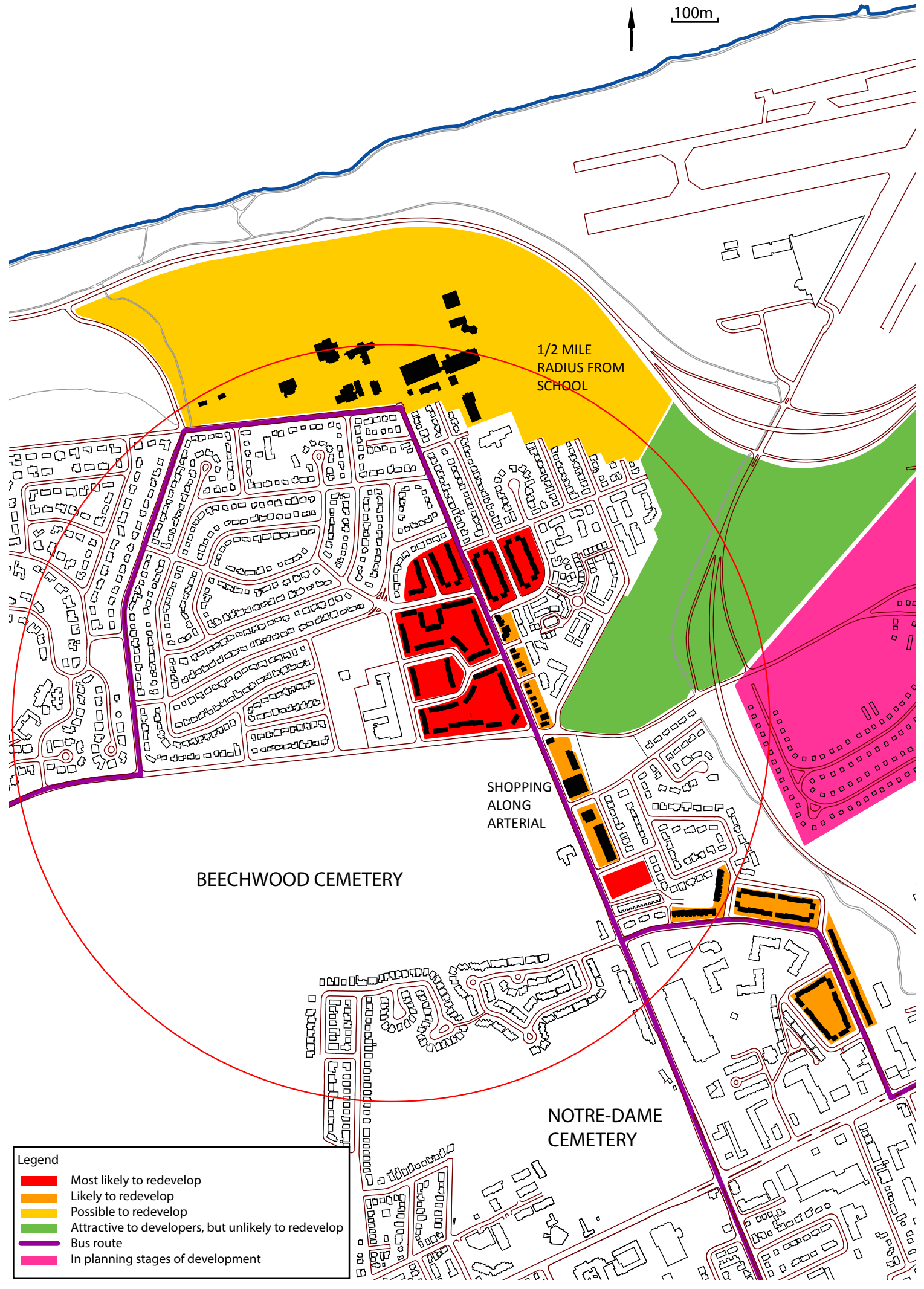

Figure 41: Manor Park development potential 
general mixed-use areas along St. Laurent Blvd. While any of the highlighted areas are likely to appeal to developers, the area in green is unlikely to develop due to flightway restrictions in place since the early 1950 s.

The lots in Manor Park most likely to redevelop are those that are both low in density and easily accessible, notably those comprising Manor Park Estates (see chapter 2, fig. 20). The site is well located, adjacent to the local elementary school and park. Constructed in the early 1950s, the townhouse blocks comprising MPE are reaching the end of their lifecycle. ${ }^{14}$ While in keeping with the low density of Manor Park, the design of MPE is quite different in form (both architectural and urban) and vocabulary from the surrounding housing. Also, as noted, the northern portions of Manor Park Estates were originally intended for shopping plazas, which were eliminated due to insufficient density to support them.

Among its objectives, then, the proposed demonstration plan seeks to revisit, reinterpret, and perhaps realize some of the original goals for the community within the context of current thinking about sustainable neighbourhood design. The objective is to provide a blueprint for redevelopment that, notwithstanding differences in form and density, is more in line with the initial goals for the community than what was actually built. Key to this endeavour is greater connectivity. By breaking up super-blocks, streets can be introduced along which a mix of uses and forms of housing can be incorporated. The authors of Retrofitting Suburbia discuss options for buffer zones of rental housing between single-family residential and areas of commercial activity, suggesting incorporating amenities that transform "separation buffers into pedestrian-oriented linkages through mixed-use redevelopment and connected streets." ${ }^{15}$ Where the existing rental housing was concerned, both renovation and replacement were considered. Given their age of and the relation of the existing terrace blocks to streets, it was determined that even the preservation of a small grouping of the existing rental housing was a less-than-optimal option. (Please see page 64 for more information regarding conservation option)

\section{Sustainability Targets}

The following issues and targets were identified to guide the (theoretical) transformation of Manor Park they can be grouped into the following categories: Intensification, Mix of Uses, Connectivity, Green Nodes and Pathways, Housing and Tenancy Options, Stormwater Retention, and Additional Guiding Principles.:

\section{Intensification}

Given its status as a low-density post-war suburb within an area designated by municipal policy for intensification, the redevelopment of Manor Park Estates may not only be desirable but unavoidable. According to Dunham-Jones et al., "the benefits of 
well-designed higher density makes feasible: land conservation, transit, a mix of uses within walking distance, and an affordable private realm, attached to a desirable public realm." ${ }^{\prime 16}$ This premise is supported by the Farr neighbourhood unit, LEED ND, and the City of Ottawa Official Plan.

Target densities for MPE draw upon LEED ND and the precedents analyzed in Chapter 3. While values for Mableton were not available, High Point increased its density by a factor of 2.3 (from an initial 716 units to around 1,700 units on 100 acres) ${ }^{17}$ but achieved a final density of only 17 units per acre (UPA). While higher than the average density of Canadian suburbs, namely 7 UPA $^{18}$, the High Point redevelopment is only slightly higher than the current density of Manor Park Estates, which is about 15 UPA.

While Manor Park's density can and should be increased, it should remain substantially lower than that of the urban core area in order to preserve the character of the area and reflect the fact that the area is not well served by transit. The proposed density for the redeveloped Manor Park Estates, was determined through an iterative design process, fits within LEED ND recommendations. While further density could be achieved by building higher, it is important to look at lowscale options, not just towers. Furthermore, the proposed design already increases the height limits along St. Laurent Boulevard by two or more storeys, depending on the location. This corresponds to the zoning changes which are discussed below.

\section{Mix of Uses}

The proximity of Manor Park Estates to St. Laurent Blvd. makes it an ideal location for mixed-use development. As the site is currently zoned R3 residential, however, a design for mixed use would require rezoning. The addition of commercial uses in this location is both consistent with the original plan for the community and appropriate for a road like St. Laurent Blvd. Locating retail and commercial uses along St. Laurent, as indicated in the demonstration plan, will afford high visibility to these establishments, while multi-unit housing above and adjacent to commercial uses will increase the density of Manor Park Estates from 15 to 35 UPA (an increase by a factor of 2.33) and the overall density of Manor Park from 5.5 to 10 UPA. This density is required to sustain local businesses and contributes to the appeal of the neighbourhood to new residents. ${ }^{19}$ Based on the Deptford and Stockwell case studies described by Ritchie and Randall in Sustainable Urban Design, the residential component of mixed-used developments should be between $70 \%$ and $80 \%$ of the gross square

\begin{tabular}{|l|l|l|}
\hline & Existing & Proposed \\
\hline Net FAR & 0.37 & 1.04 \\
\hline $\begin{array}{l}\text { Total Number } \\
\text { of Units }\end{array}$ & 342 & 799 \\
\hline UPA & 15 & 38 \\
\hline
\end{tabular}

Figure 42: Table comparing existing and proposed figures for the Manor Park Estates demonstration plan 
footage. ${ }^{20}$ Taking into consideration the fundamentally residential character of Manor Park, however, the redevelopment targets a ratio of approximately $90 \%$ residential to $10 \%$ non-residential across the neighbourhood. Again, this was arrived at empirically, by assessing the capacity of St. Laurent Blvd. to accommodate commercial usages and associated parking.

\section{Connected Street Grid and Walkability}

When constructed, the MPE terrace homes were laid out on exceptionally large, deep lots. The existing configuration is out of sync with current thinking about block size and proportion, according to both Traditional Neighbourhood Development ${ }^{21}$ and LEED ND standards. To efficiently provide all of the housing and services that will be required by a higher density, the existing street grid must be adjusted to accommodate better connectivity for all means of transportation, but especially to encourage alternate modes such as walking and cycling. Changes to the street layout should increase internal integration ${ }^{22}$ as well as improve alignment with surrounding streets as per DPZ's adaptation of Perry's neighbourhood diagram. Following the examples of Mableton and High Point, the new street grid will break up larger blocks, aligning new streets with existing streets and providing ample shaded sidewalks.

\section{Green Nodes and Pathways}

Public greenspaces, provide many benefits to urban neighbourhoods. From an environmental perspective, they are the lungs of the city whose vegetation enables a purification of the air, while providing a habitat for small animals. From a social perspective, access to parks and open spaces can have positive effects on the physical and emotional health of residents. All three neighbourhood diagrams studied reserve key sites for parks, while the Farr diagram goes further by framing the neighbourhood with "habitat and infrastructure greenways." The demonstration plan will strive to work within the limitations of an existing neighbourhood to provide quality open spaces, that enable a connection between local parks.

\section{Housing and Tenancy Options}

The availability of a variety of housing options is not only consistent with the history of Manor Park but will promote social inclusion. The integration of multiple housing types, sizes and tenancy options is necessary to accommodate households of different profiles and economic levels. As we have seen, High Point is an example of an income-integrated development. Designers were able to utilize various techniques to diversify the units and produce a cohesive neighbourhood with even numbers of affordable and market units. ${ }^{23}$

"The available housing types, which include single-family attached and detached homes, duplexes, and multifamily units, offer residents a range of housing options to meet their individual needs. Breaking up the massing of the buildings and conservative height restrictions 
allow for a significant increase in the number of housing units on the site (16-25 units per acre) without compromising the goal of creating a neighborhood-scaled, pedestrian-friendly community." 24

Although owned by a private company and operated on a for-profit basis, Manor Park Estates has been subject to residualization. ${ }^{25}$ As a result, the 342 units rent at relatively affordable rates. In exchange for the changes to zoning necessary to permit intensification and a mix of uses, the City of Ottawa could use Section 37 of The Planning Act to encourage the developers to include affordable housing. While ideally the developer would provide at least 342 affordable units, the number may need to be negotiated down to about $15 \%$ of all the units ${ }^{26}$ (about 112 units) if other community amenities are provided. To the greatest extent possible, the affordable housing should take the form of family-friendly ground-level units with private yards not only because this most closely matches the existing MPE terrace housing but because families have the most difficulty finding affordable housing. To avoid stigmatization, these units should be indistinguishable from and integrated with similar, market-rate units. To facilitate the integration of affordable housing and to be in a better position to leverage grants and tax breaks, responsibility for this housing might be turned over to an experienced affordable housing provider such as Centertown Citizens Ottawa Corporation (CCOC) (the second largest affordable housing provider in the city behind the city itself).

\section{Stormwater Retention}

In terms of environmental sustainability, stormwater retention will be integrated into the site design. As discussed in Chapter 3, stormwater retention was a key component of the redevelopment of High Point, where both bioswales along the streets, and a retention pond greatly reduced strormwater runoff to the nearby stream. ${ }^{27}$ Ottawa's Official Plan includes a Stormwater Management section, that addresses issues of the quantity and quality of runoff from

\begin{tabular}{|l|l|l|l|}
\hline Building Types & 1 Bedroom Units & 2 Bedroom Units & 3 Bedroom Units \\
\hline Semi-Detached & & & 22 \\
\hline Stacked Towns & & 36 & 44 \\
\hline Flats-over-Towns & 62 & 26 & 36 \\
\hline 4.5 Storey Walk-Ups & & 162 & 81 \\
\hline $\begin{array}{l}\text { Residential over Com- } \\
\text { mercial }\end{array}$ & 140 & 114 & \\
\hline 20 Storey Tower & & 76 & 183 \\
\hline Total & 202 & 414 & \\
\hline
\end{tabular}

Figure 43: Table showing breakdown of unit types proposed in the Manor Park demonstration plan 
rain events. The City of Ottawa promotes intensification of existing areas "while not exceeding the capacity of existing stormwater/ storm drainage infrastructure."28 Essentially, this provision requires redevelopment sites to manage their own stormwater. In Manor Park, the goal is to apply natural stormwater retention techniques, similar to those used at High Point, so that the redevelopment will put no net increase in demand on the municipal storm sewer system over the existing MPE.

\section{Additional guiding principles}

In addition to the sustainability targets listed above, the following principles have informed the proposed demonstration plan for Manor Park:

- Respect and enhance character of Manor Park,

- Careful transitions to existing lowscale portions of the neighbourhood,

- Keep tall buildings and commercial to arterial roads,

- Keep surface parking to the middle of the block,

- Provide community amenity space

- Onsite energy generation 


\section{Project Description- Analysis Diagrams}

\section{Manor Park Figure-Ground Diagram}

The suburban nature of Manor Park is evident in figure 44. Based on the building sizes and shapes, it is easy to distinguish areas of low density, single-family dwellings, from larger-scale multi-family dwellings and large institutional or commercial structures. The large, mid-block spaces in MPE are easily visible.

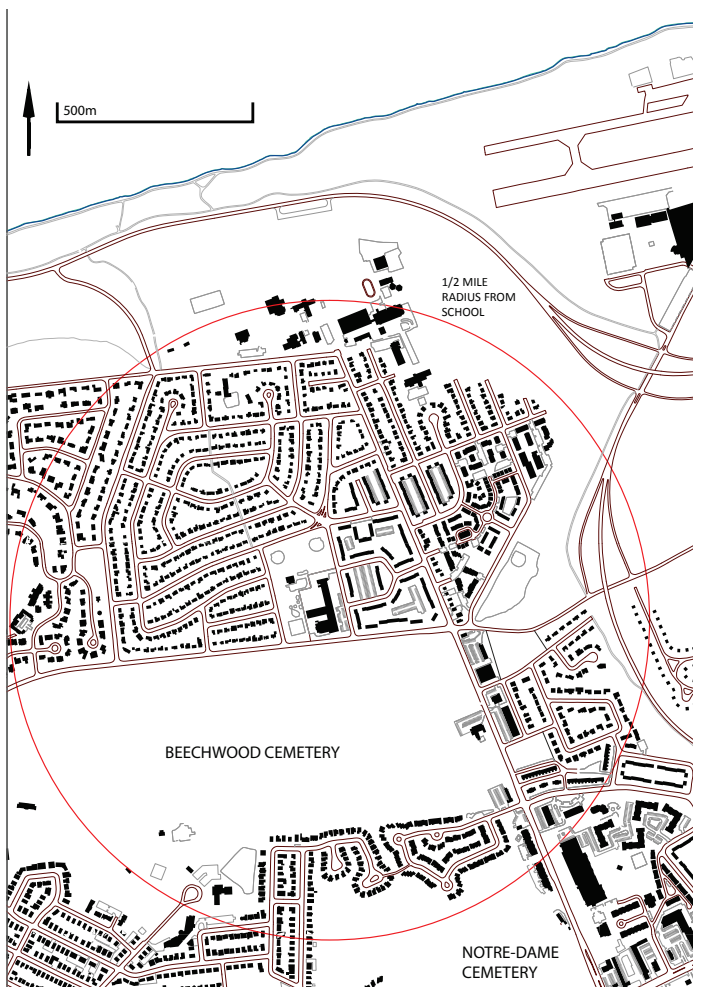

Figure 44: Manor Park figure-ground analysis

\section{Manor Park Natural Features}

Figure 45 shows the mature trees and forested areas as well as the major contour lines of Manor Park. From this diagram, it is evident that overall Manor Park and its surroundings contain many mature trees, and forested areas. By contrast, MPE is sparsely treed. With respect to topograpy, the area is relatively flat, with most surface variations occurring along the river's edge and within Beechwood cemetery. It is interesting to note that road configurations roughly follow contour lines, a practice recommended in the 1940s by the FHA in the U.S., ${ }^{29}$ possibly also by CMHC.

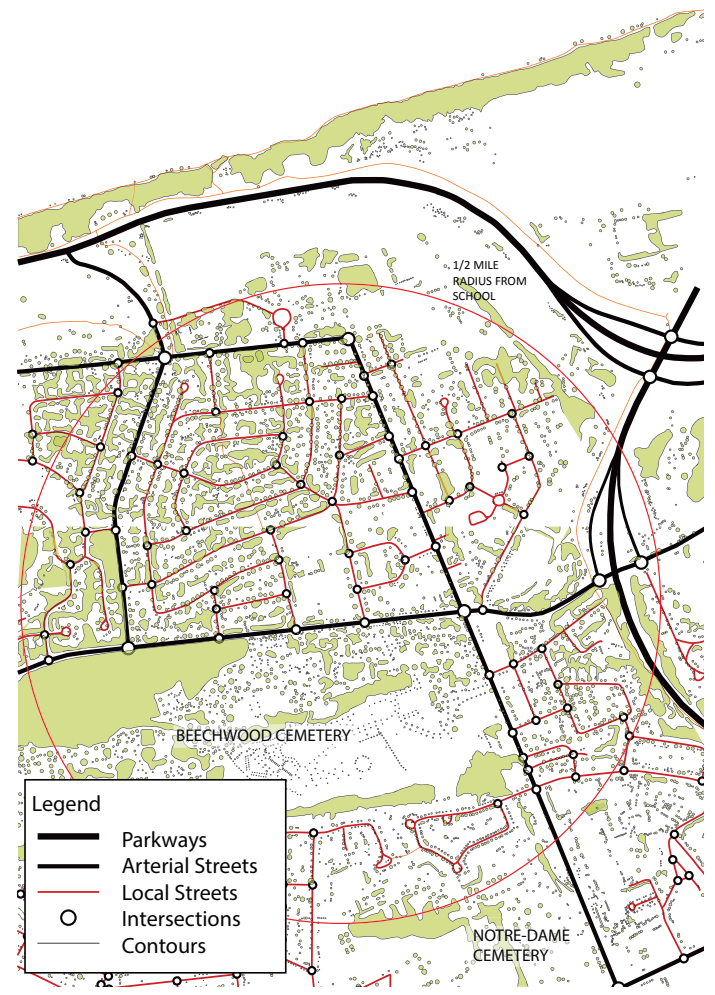

Figure 45: Manor Park natural features 


\section{Circulation And Block Size}

It is clear from figure 46 that, in comparison to many suburban communities, Manor Park is relatively well connected as it makes minimal use of cul-de-sacs. However, its long blocks and offset street intersections favour cars over pedestrians. Some existing cul-de-sacs could easily be joined to improve connectivity.

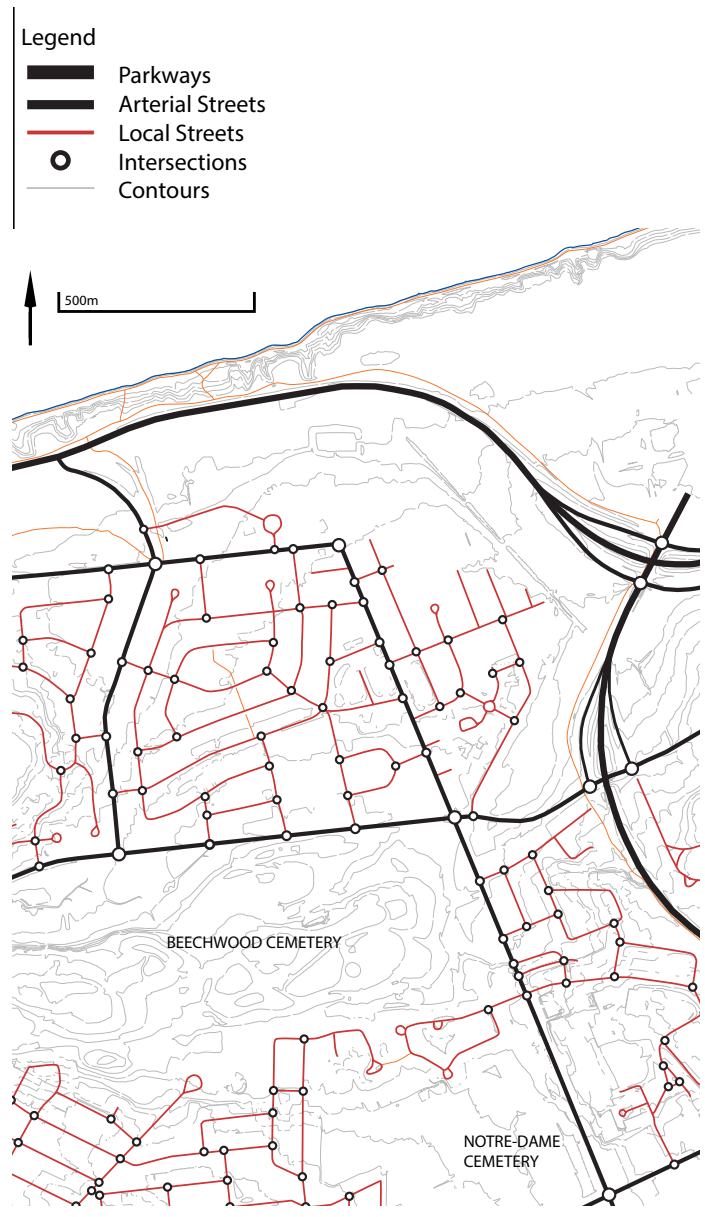

Figure 46: Manor Park existing circulation and block size

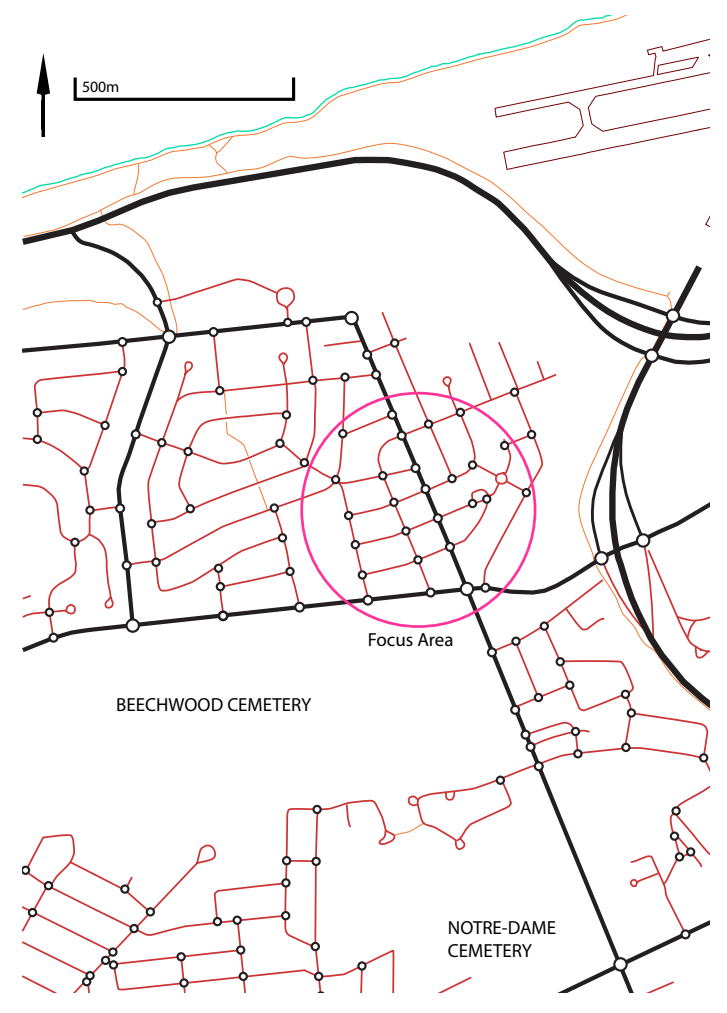

Figure 47: Manor Park proposed circulation and block size 


\section{Manor Park Zoning}

Zoning designations in Manor Park reinforce

the residential nature of the suburb - the majority of the area being zoned for residential uses (Fig. 49). Zoning for low-density, single-family dwellings dominates the north western portion of the neighbourhood, while higher density residential is permitted along St. Laurent in two nodes: one to the north of Hemlock, the other around Brittany Ave. Separating these is a general mixed-use area that could incorporate a variety of uses including commercial and residential, up to a height of 6 storeys. Lands to the north, are designated institutional, including the RCMP lands mentioned previously.

\begin{tabular}{|l|l|l||}
\hline Designation & Title & Permitted Uses \\
\hline R1 & Residential first density zone & Primarily detached single family dwellings \\
\hline R2 & Residential second density zone & Detached and two unit buildings \\
\hline R3 & Residential third density zone & $\begin{array}{l}\text { Amix of dwelling types from detached to } \\
\text { townhouses }\end{array}$ \\
\hline R4 & Residential fourth density zone & $\begin{array}{l}\text { A mix of dwelling types from detached to low- } \\
\text { rise apartments }\end{array}$ \\
\hline R5 & Residential fifth density zone & $\begin{array}{l}\text { A mix of dwelling types from detached to mid- } \\
\text { rise apartment }\end{array}$ \\
\hline GM & General mixed-use zone & $\begin{array}{l}\text { A mix of residential, commercial and institu- } \\
\text { tional uses, or mixed use development }\end{array}$ \\
\hline I1 & Minor institutional zone & $\begin{array}{l}\text { A range of community uses, institutional ac- } \\
\text { commodation and emergency service uses, } \\
\text { compatible with neighbourhood character }\end{array}$ \\
\hline L1 & Community leisure facility zone & $\begin{array}{l}\text { Recreational uses that meet the needs of } \\
\text { the surrounding community, compatible } \\
\text { with adjacent residential uses (also includes } \\
\text { cemetaries) }\end{array}$ \\
\hline *Information adapted from: “City of Ottawa Zoning By-Law." City of Ottawa. http://ottawa.ca/en/residents/ \\
\hline
\end{tabular}

Figure 48: Zoning reference table 


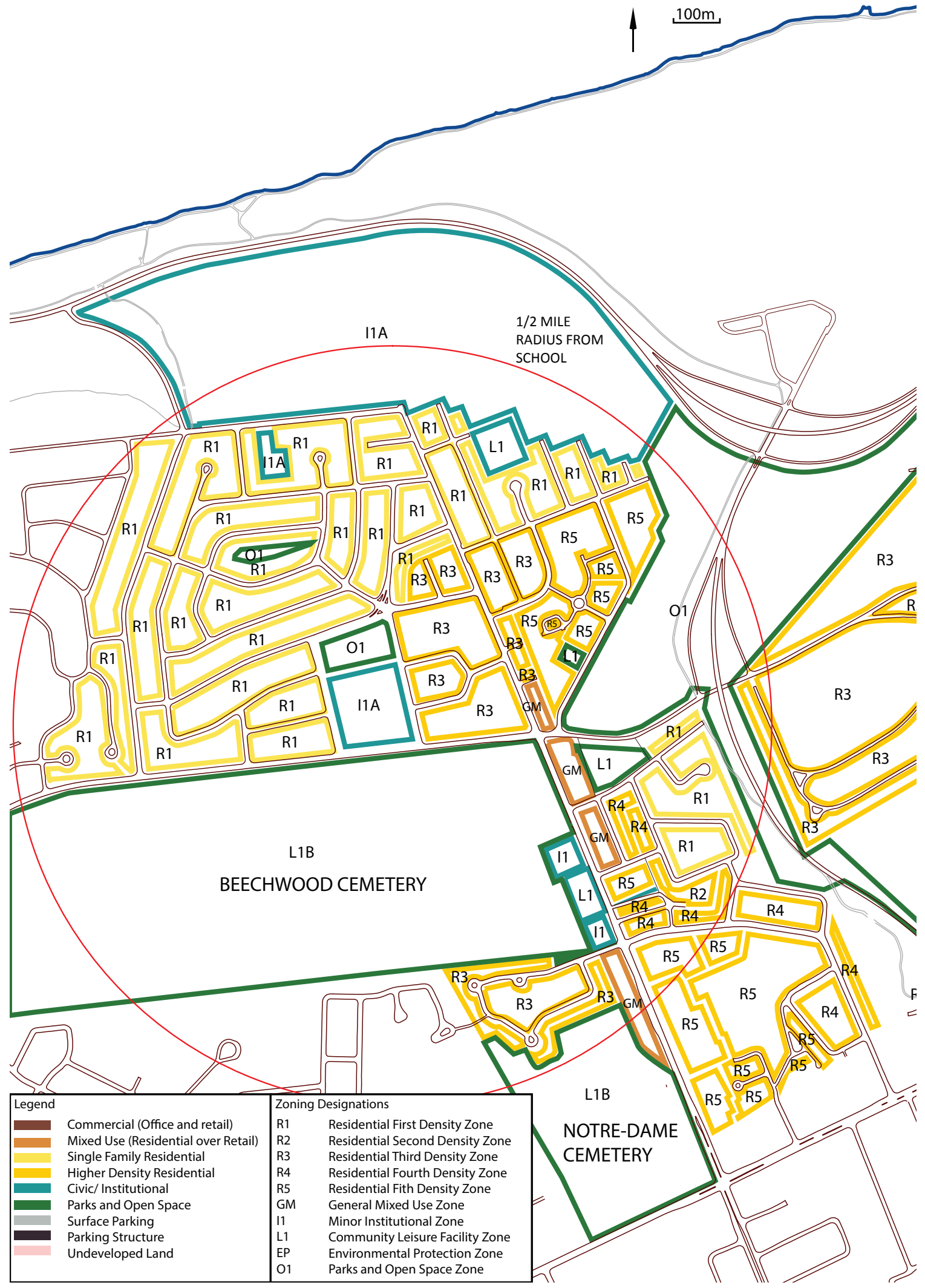

Figure 49: Manor Park zoning map 


\section{BROAD STROKES}

Before focusing on the MPE site, the following are a few broad suggestions improve the overall Manor Park area. (Fig. 50 - 52) Create connections where cul-de-sacs line up across blocks. A further connection between Hemlock and Aviation parkway through southbound access might be considered as the development of CFB Rockcliffe goes on. Transform Hemlock into a parkway, as its proximity to Canada's National cemetery (Beechwood), makes it appropriate for this street to take on enhanced significance. Transformation might follow the Farr neighbourhood diagram by widening the street in order to accommodate a planted median that would serve the dual purposes of calming traffic and retaining stormwater.

Highlight the community center. As previously discussed, Manor Park was developed in two phases, and underwent several changes between planning and completion. Over the course of its development the two neighbourhood units evolved into a single, larger neighbourhood, losing clarity in the process. Clarence Perry highlighted the importance of the center for civic uses; while maintaining its importance, DPZ and Farr Associates envisioned the centre as a mixeduse area. It might be relevant to re-introduce the idea of two distinct neighbourhoods in Manor Park, one to the north and one to the south of Hemlock, as there already exists an architectural distinction between these two areas. To this end individual neighbourhood nodes might be created. For the southern portion, a node might develop in proximity to existing churches along St. Laurent, while to the north, the site previously designated for a shopping center is ideally situated to become a neighbourhood center. The intersection of these two neighbourhood units, located at Hemlock and St. Laurent, would also become an important feature, as it could serve as the gateway to both neighbourhoods. The proposal below focuses on the northern neighbourhood, and also provides an idea of what the intersection of the neighbourhoods might become.

The combination of increased population density and a more clearly defined core will likely encourage the redevelopment of the general mixed-use areas south of Hemlock. The commercial node (currently strip malls) on the southeast corner of Hemlock and St. Laurent could be designed to accommodate larger, national retailers by providing commercial areas with wider floor plates than those provided for local retailers along the 'main street' north of Hemlock. In accommodating national stores, it is even more important that the architectural design be locally sensitive. Large parking areas that often overwhelm these kinds of developments should be located below ground, allowing the area to function as a pedestrian shopping plaza similar to London's Duke of York Square (Fig. 53 -54). A double row of shops would significantly increase the amount of retail space in a low-rise form. While offices might be located above the commercial along 


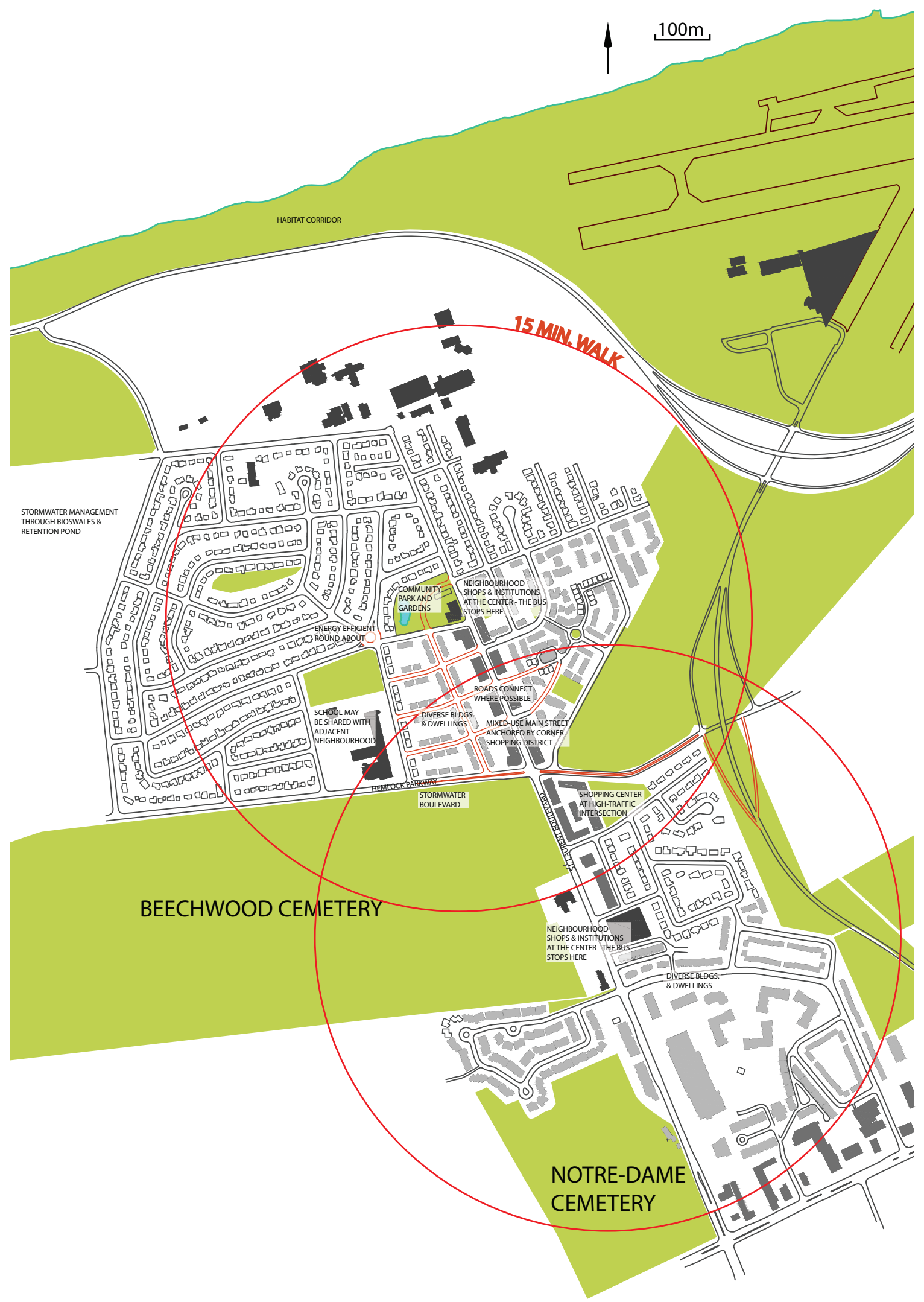

Figure 50: Diagram of broad strokes including new comunity centers and shopping node 
St. Laurent, the second, more private row could include residences that would keep the area lively at all times and enjoy views over Hemlock Park to the rear. Although the creation of this plaza would require the conversion of a portion of Hemlock Park, the area is well served by parks (e.g., London Terrace Park, directly across Hemlock to the north) and the redevelopment includes an additional park north of Eastbourne Ave. (discussed below). Additionally, the resulting hardscaped public space could be used for many community events such as a weekly farmers market. (Fig. 55)

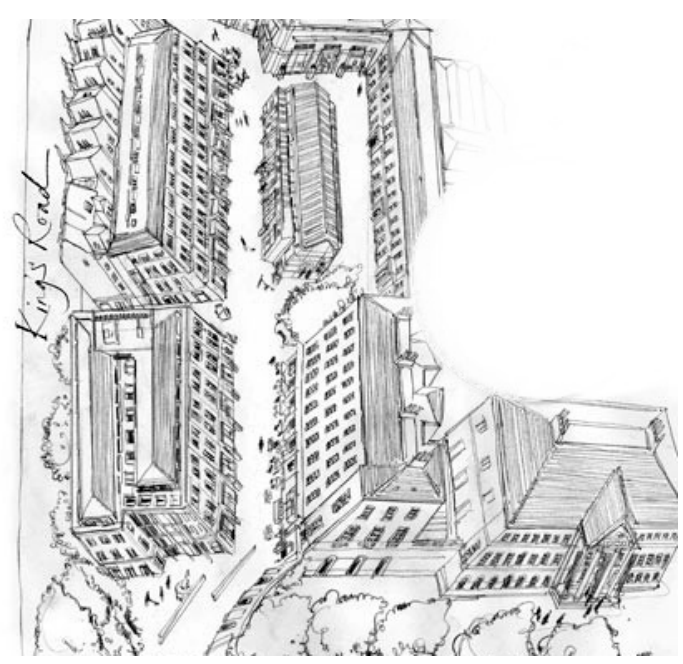

Figure 54: Illustration of Duke of York Square

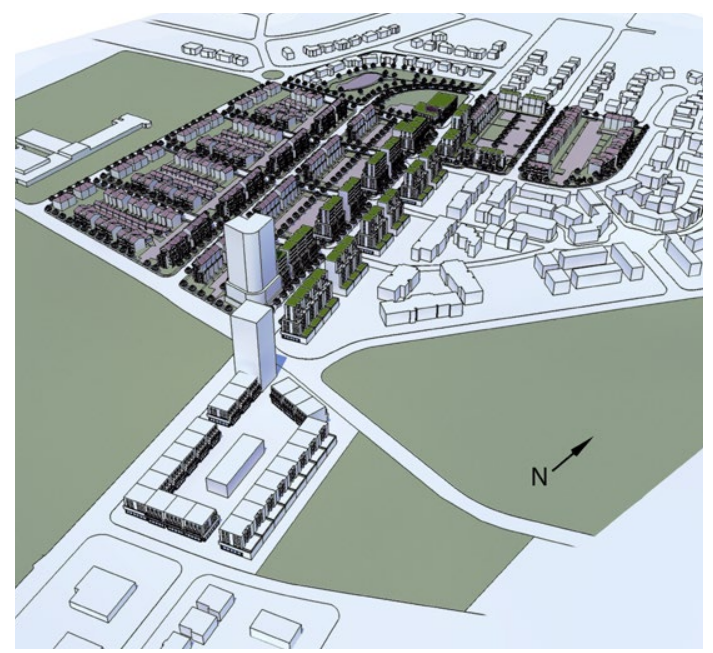

Figure 51: Aerial view of demonstration plan from south

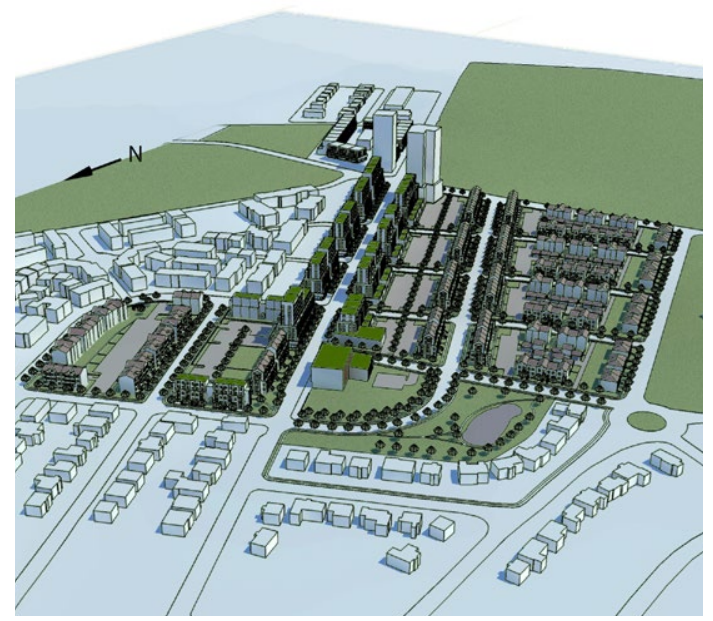

Figure 52: Aerial view of demonstration plan from north

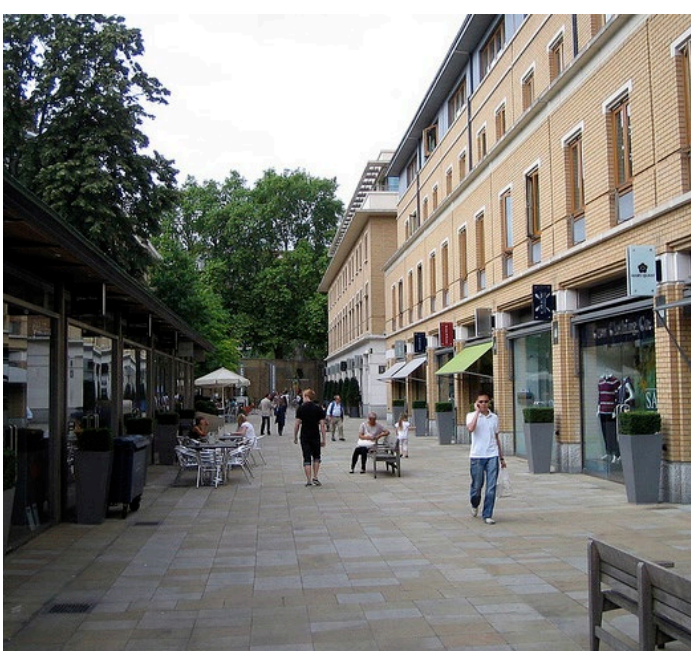

Figure 53: Photograph of Duke of York Square 


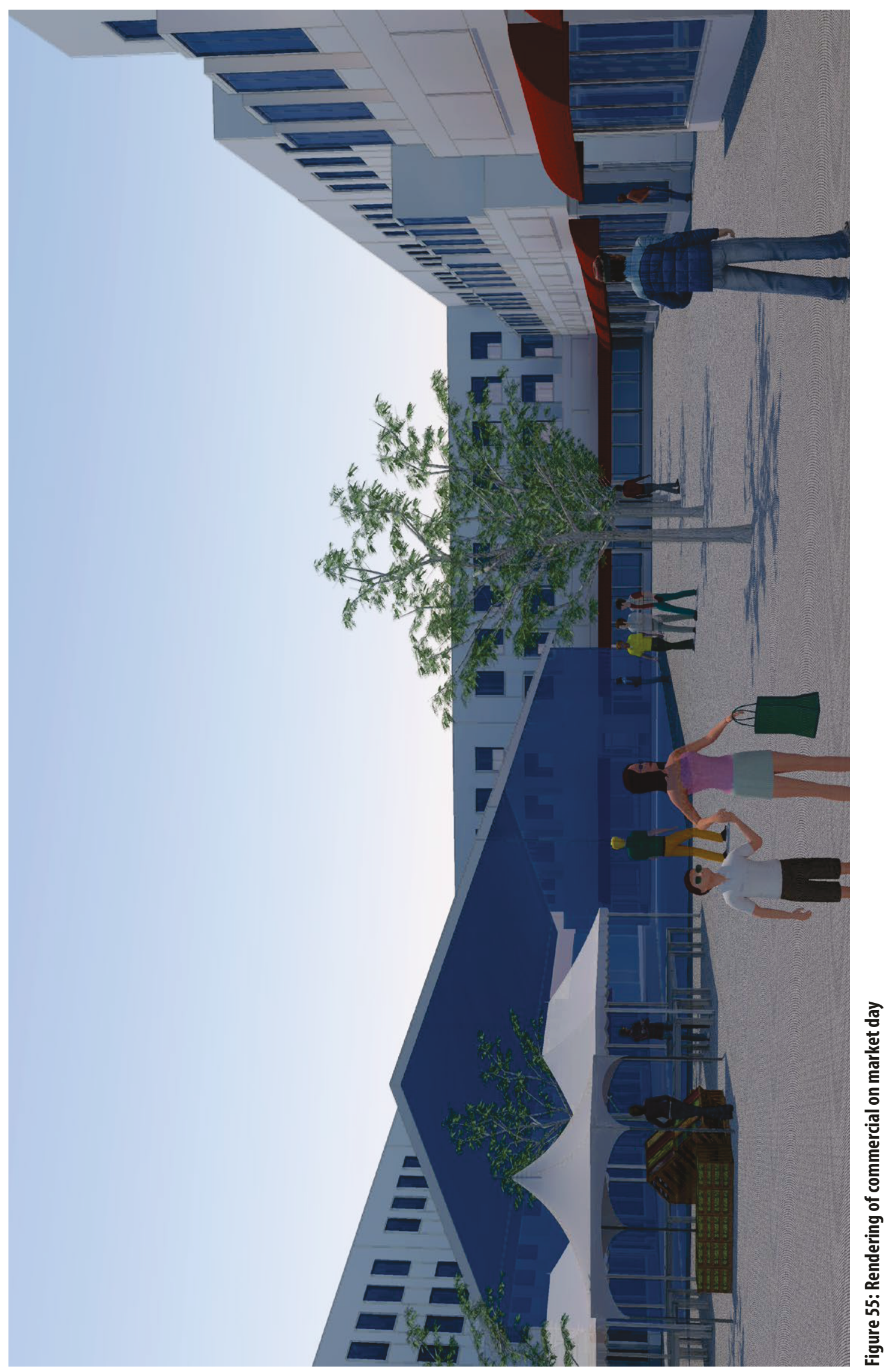




\section{Increased Connectivity}

Connectivity should be improved through the MPE site. To accomplish this, the eastwest street grid should be modified to span the entire site, aligning with streets across St. Laurent Blvd. A north/south street should be added to the west of St. Laurent, the north end of which would curve around to meet Blasdell Ave. (Fig. 47 \& 56) This new street replaces existing street segments in a more unified manner and provides a transition between the mixed-use areas along St. Laurent and the more uniformly residential areas to the west. The new streets should intersect at right angles to provide the best visibility to drivers and safety for pedestrians.

Again an iterative design process was used to determine the best combination of street connectivity and block size, with an emphasis on accommodating different uses and

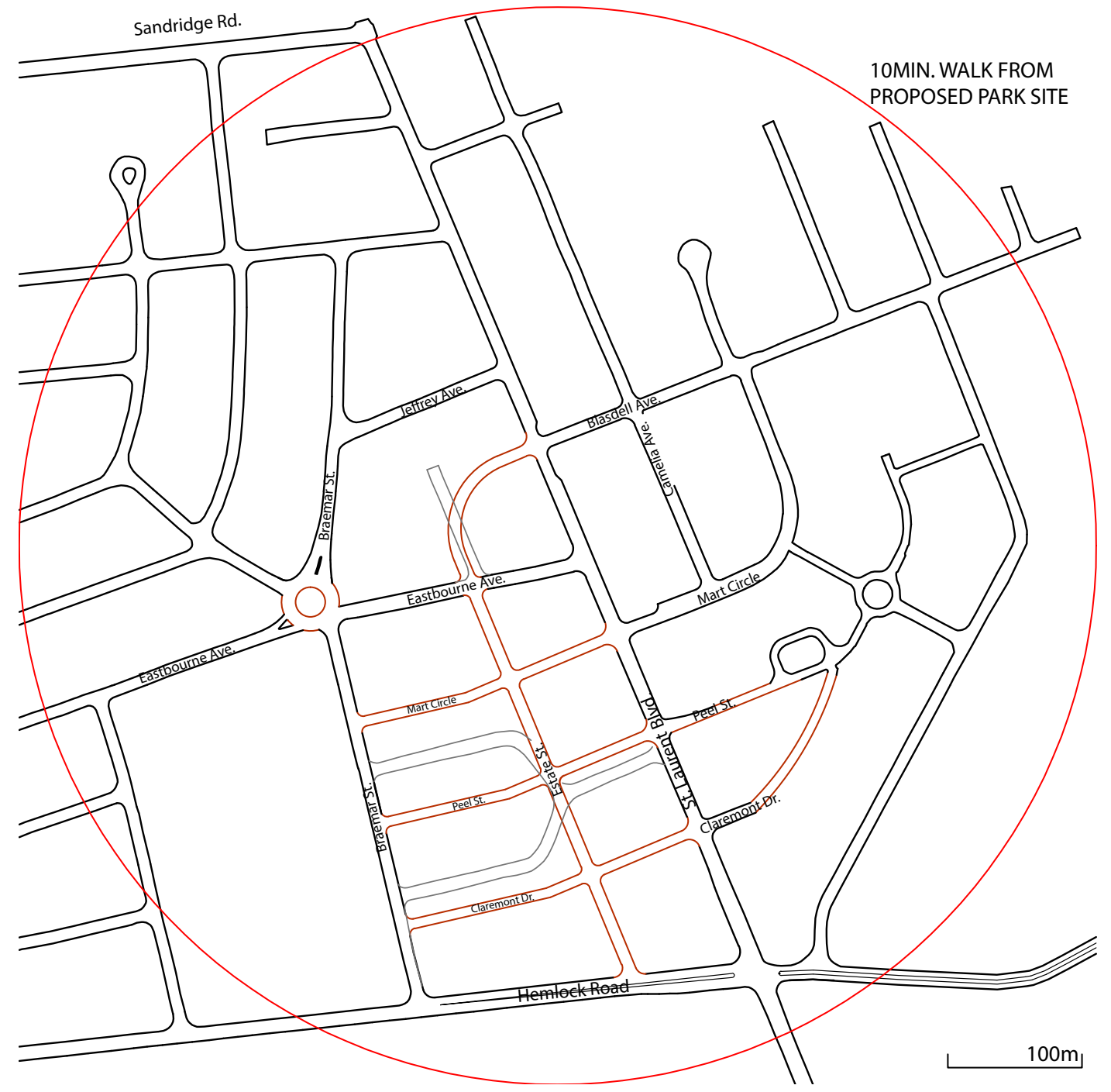

Figure 56: Large scale new street plan diagram 

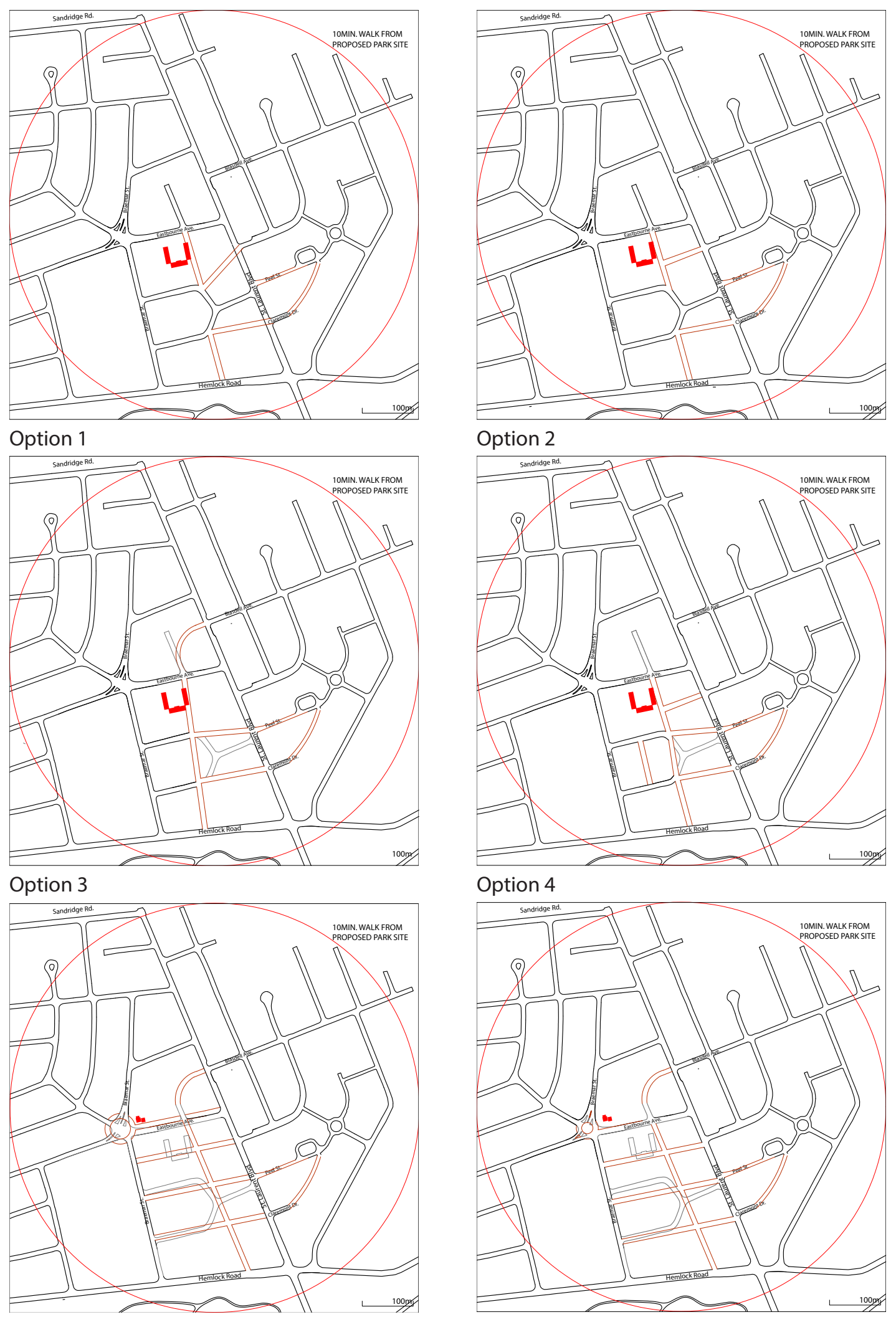

Option 5

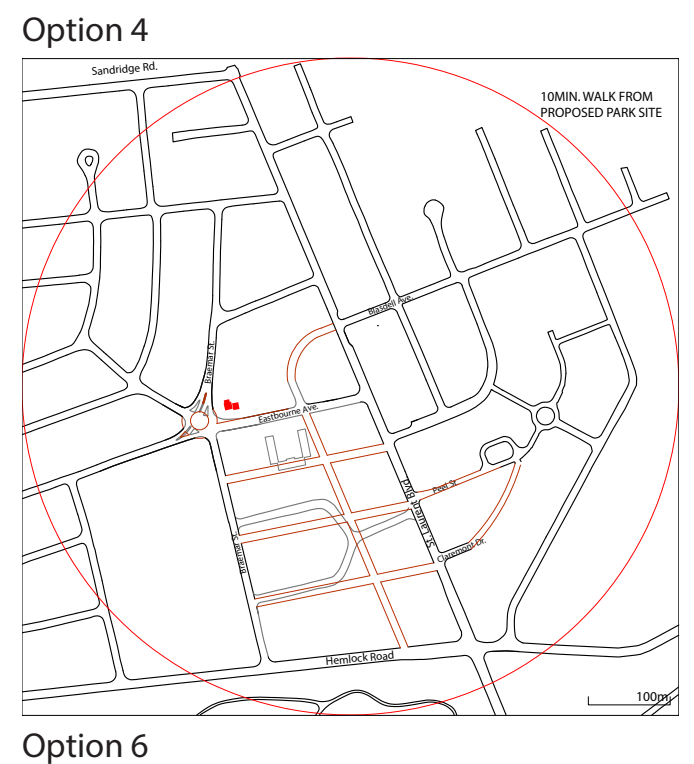

Figure 57: Diagrams of street grid options tested 


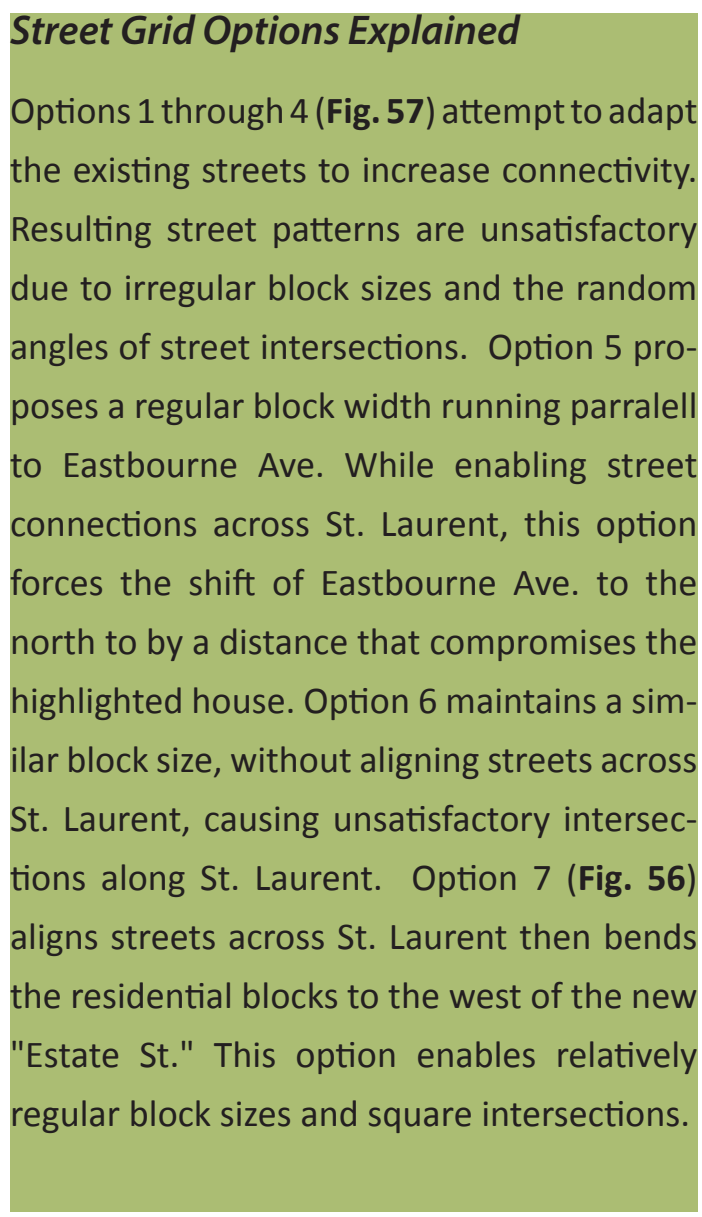

parking. (Fig. 57) As in the neighbourhood unit, streets and blocks should be sized reflect their use. Narrow, residential streets encourage slower traffic, while wider, arterial streets provide curbside parking for retail shops (Fig. 58). The lack of proximity to a major transit node means that the car is likely to remain an important mode of transportation in Manor Park and due diligence must be given to parking. Blocks that integrate commercial uses might need to be deeper to provide additional off-street parking. Although necessary, the visual impact of surface parking can be mitigated by creating mid-block laneways and shared parking areas.

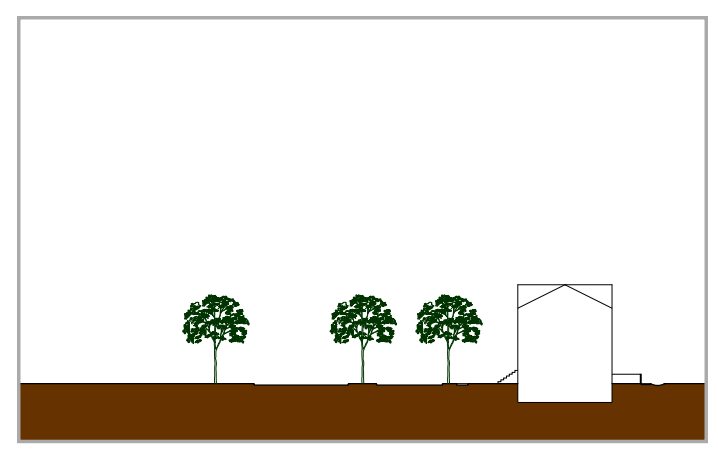

Hemlock Looking West

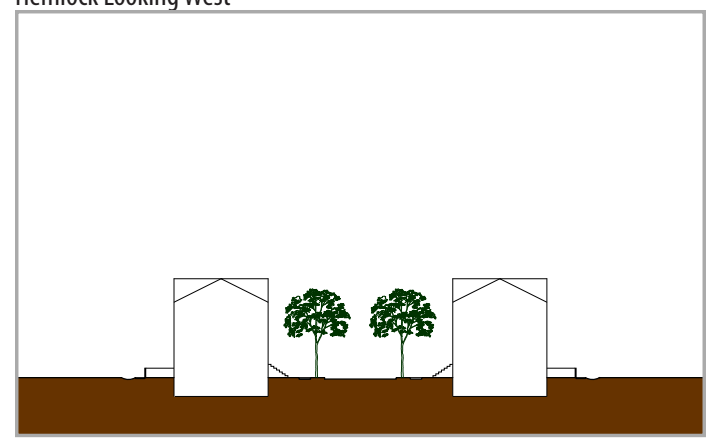

Residential Street Section

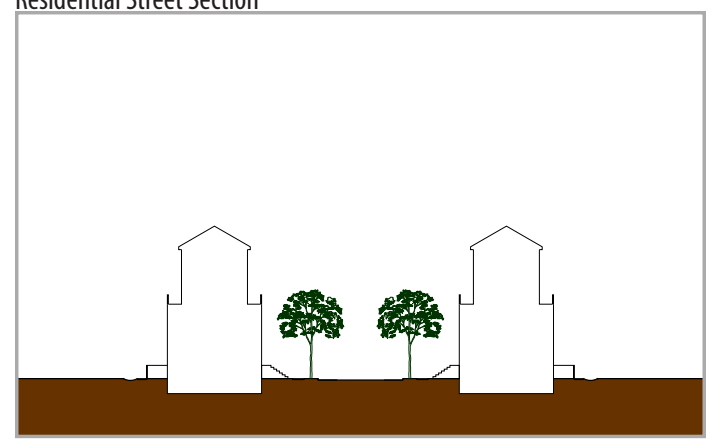

Estate Street Section

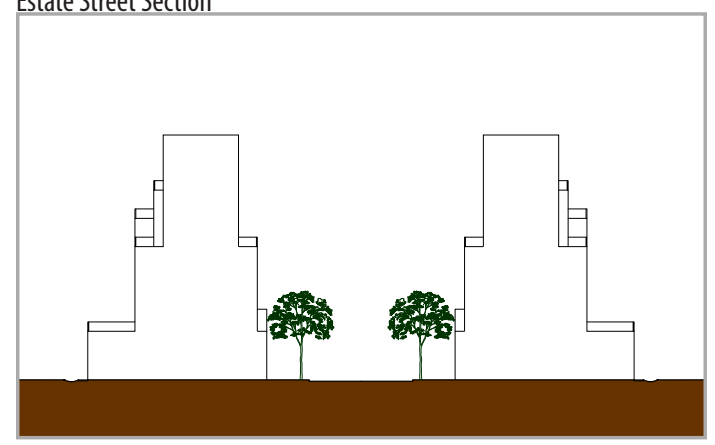

St. Laurent Blvd. Section

Figure 58: Street sections 


\section{Conservation Option}

Given their age, the terraces comprising MPE may be of historical significance. Although no historical designation exists, it may be pertinent to consider preserving one or more of these blocks for posterity. Complicating matters, however, is the loose relationship of these terraces to the surrounding streets and the scale of the mid-block spaces. A U-shaped grouping of buildings, featured prominently in the original rental brochure for the area, was identified as the most likely fragment to be kept. (Fig. 59 - 62) All of the options for new street and block layouts (Fig. 57, Opt. 1 - 4), however, required the renovation of the facades of these buildings to address new streets at their rear - renovations that would likely compromise their historical status. Alternatively, keeping the court without the addition of a north-south street meant maintaining a superblock, which reduced the possibilities for intensifying the site. In the end, it was determined that the remnant should be sacrificed in favour of a more cohesive neighbourhood design.

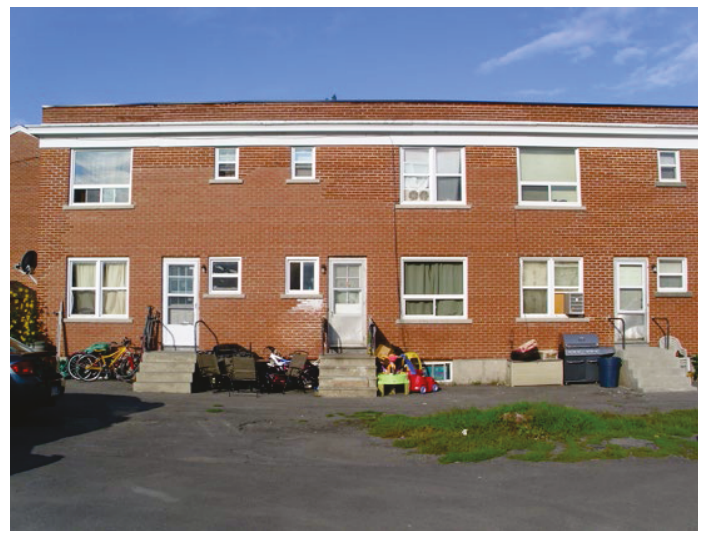

Figure 62: Current photo of rear of rental court

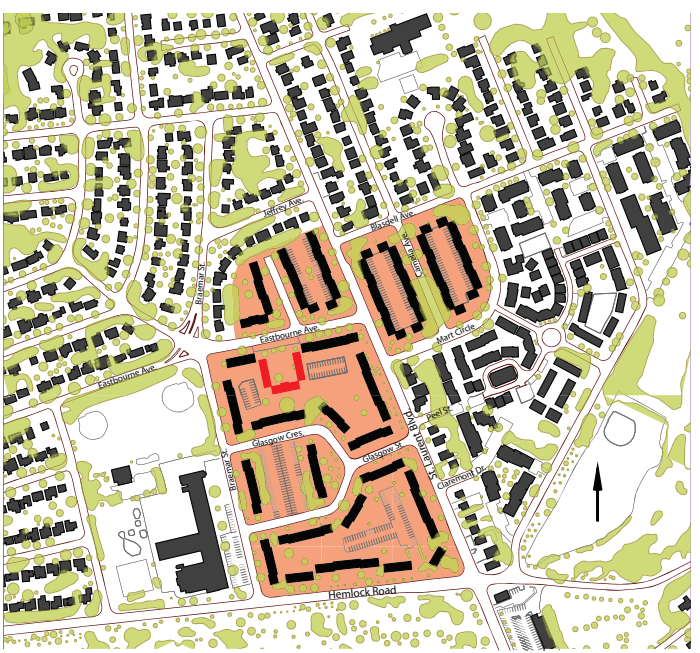

Figure 59: Plan showing potential historic fragment

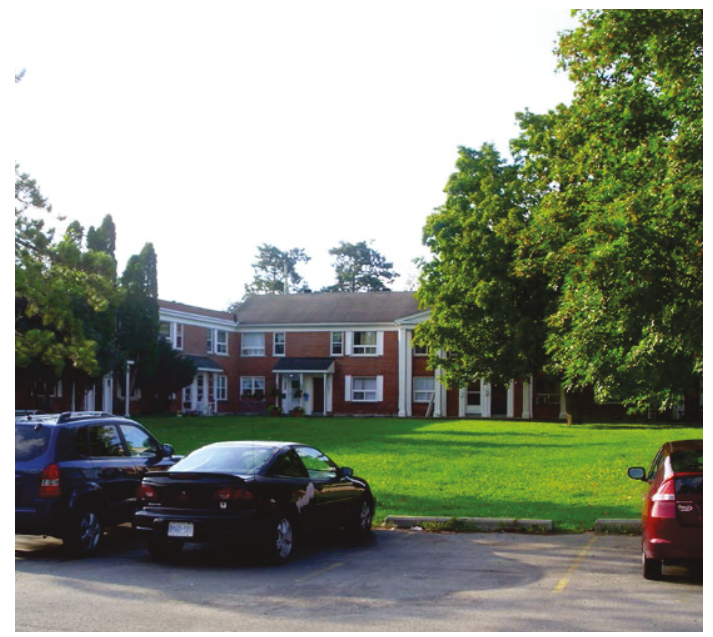

Figure 60: Current photo of rental court

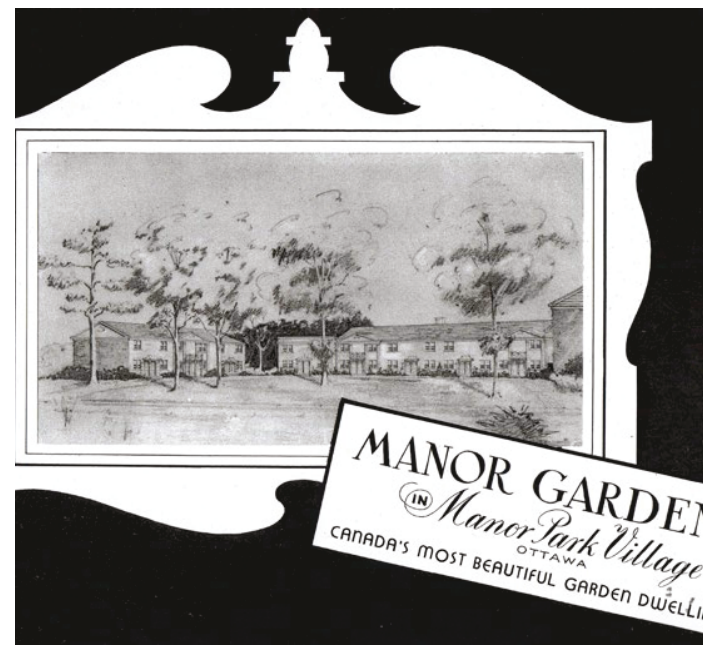

Figure 61: Rendering from 1950 rental brochure 


\section{Final Proposal- Description of The Design Project}

The final demonstration plan has been created based on the sustainability targets, and design guidelines above, as well as an understanding of precedents and LEED ND. The proposed intensification of MPE uses a new street grid as an armature to achieve the above. It has been designed to adjoin with adjacent streets, maintain perpendicular intersections, etc. The grid was then in-filled in a number of ways: mixed-use along St. Laurent, terminating in a community center node, and residential at various densities making up the surrounding areas (Fig. 63).

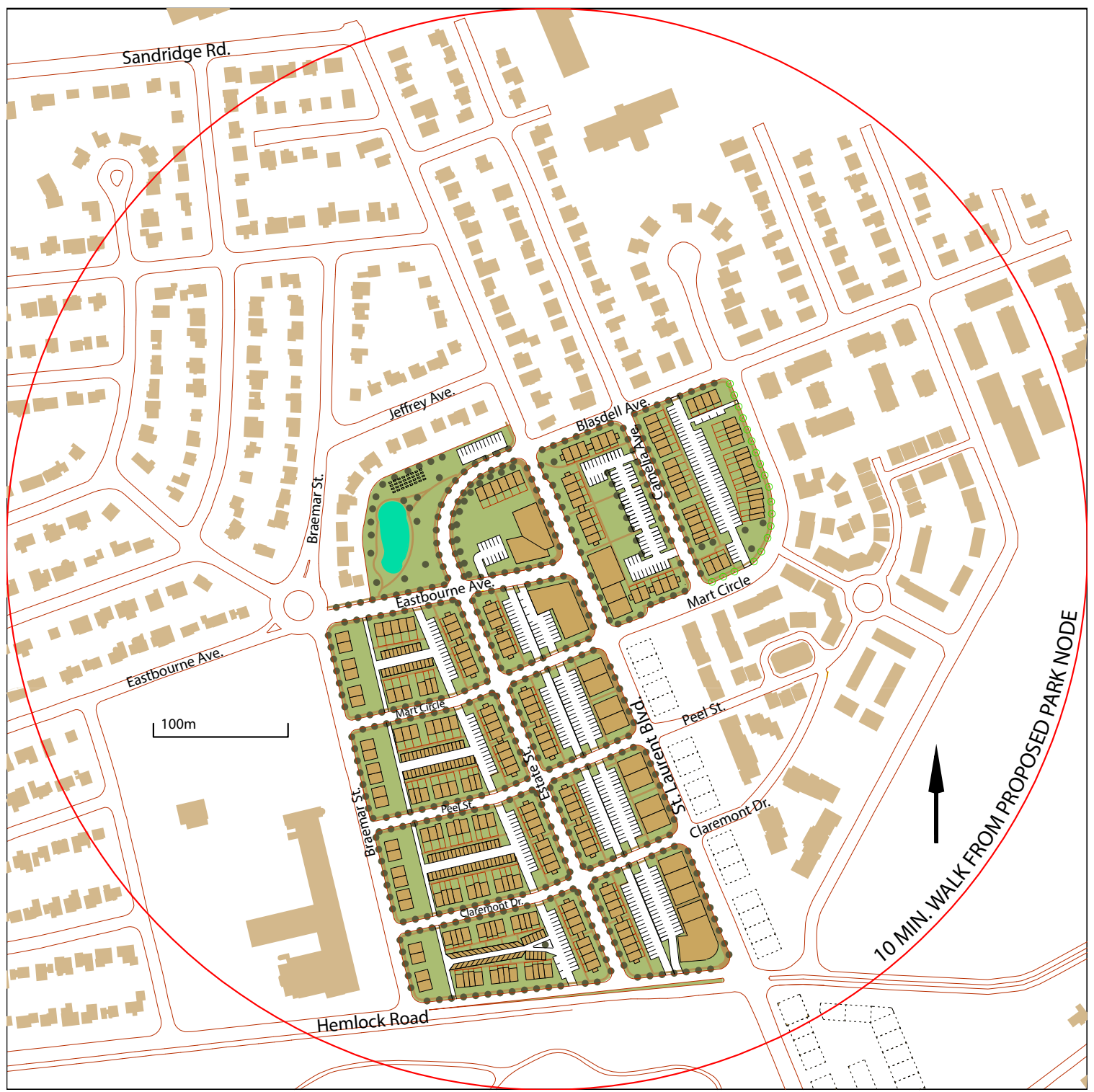

Figure 63: Proposed plan for Manor Park Estates 


\section{Exploring St. Laurent}

Taking cues from Mableton, the demonstration plan for MPE creates multiple nodes. The first, as noted above, is a high-density node at the intersection of Hemlock and St. Laurent, using towers to create a visual gateway to the community. (Fig. 65) The shopping plaza described above would be integrated into this node.

Complementing the node at Hemlock and St. Laurent, a park and community center have been located at the northeast corner of St. Laurent and Eastbourne. (Fig. 64 \& 66) The 'naturally' landscaped public park serves to enhance both the environmental and social dimensions of the neighbourhood. A central water feature functions as a retention pond, while pathways encircling the pond enable leisurely promenades, intended, "to improve physical and mental health and social capital." ${ }^{30}$ The northwest corner of the park has

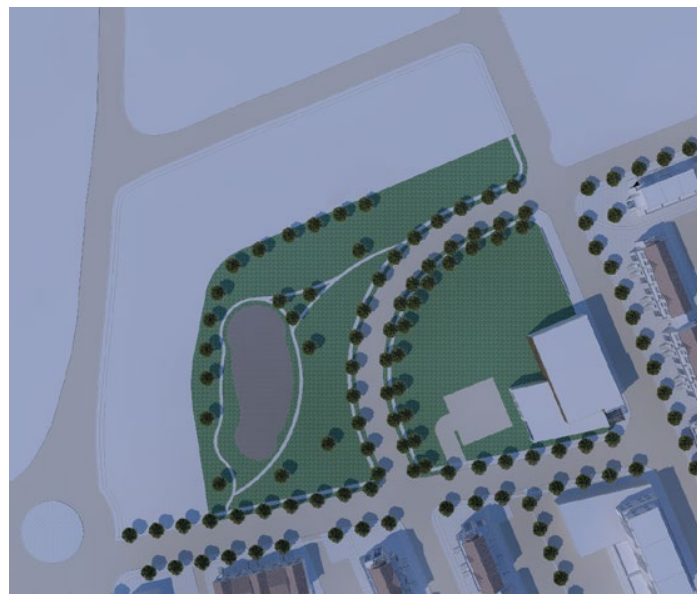

Figure 66: Large scale plan of park node been reserved for community gardens, providing space for residents, particularly those who live in apartments, to grow their own produce.

The community center could benefit from its proximity to the park for community events. The building could incorporate a district heating center, below ground, while providing community space and facilities above. The implementation of a solar thermal district

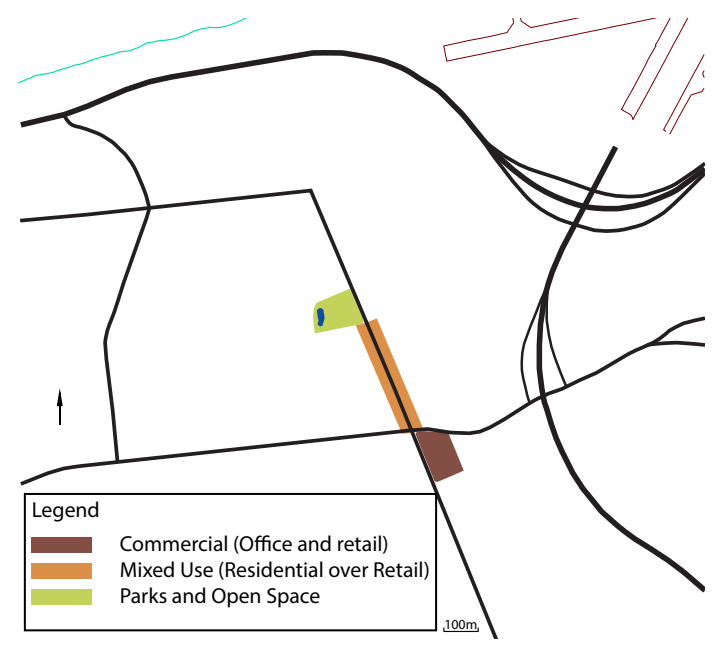

Figure 64: Parti diagram showing proposed park and commercial nodes, connected by a mix of uses along St. Laurent Blvd.

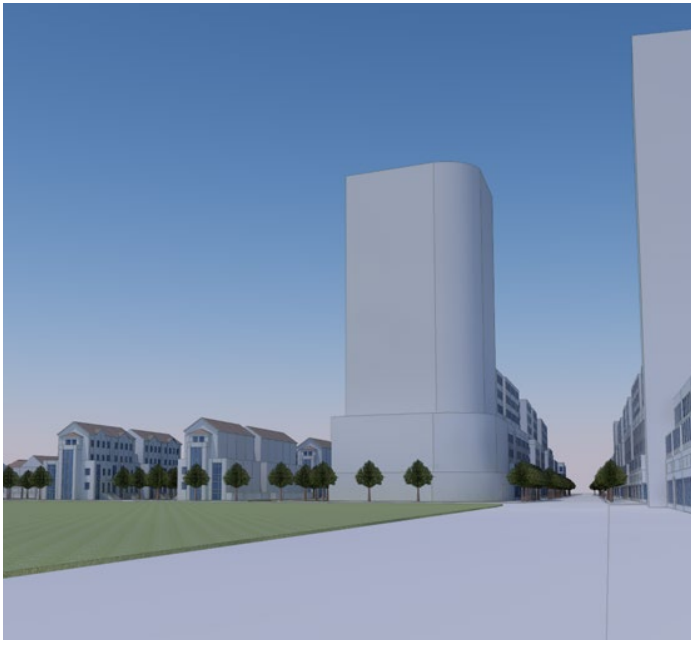

Figure 65: Vignette of towers at Hemlock and St. Laurent 


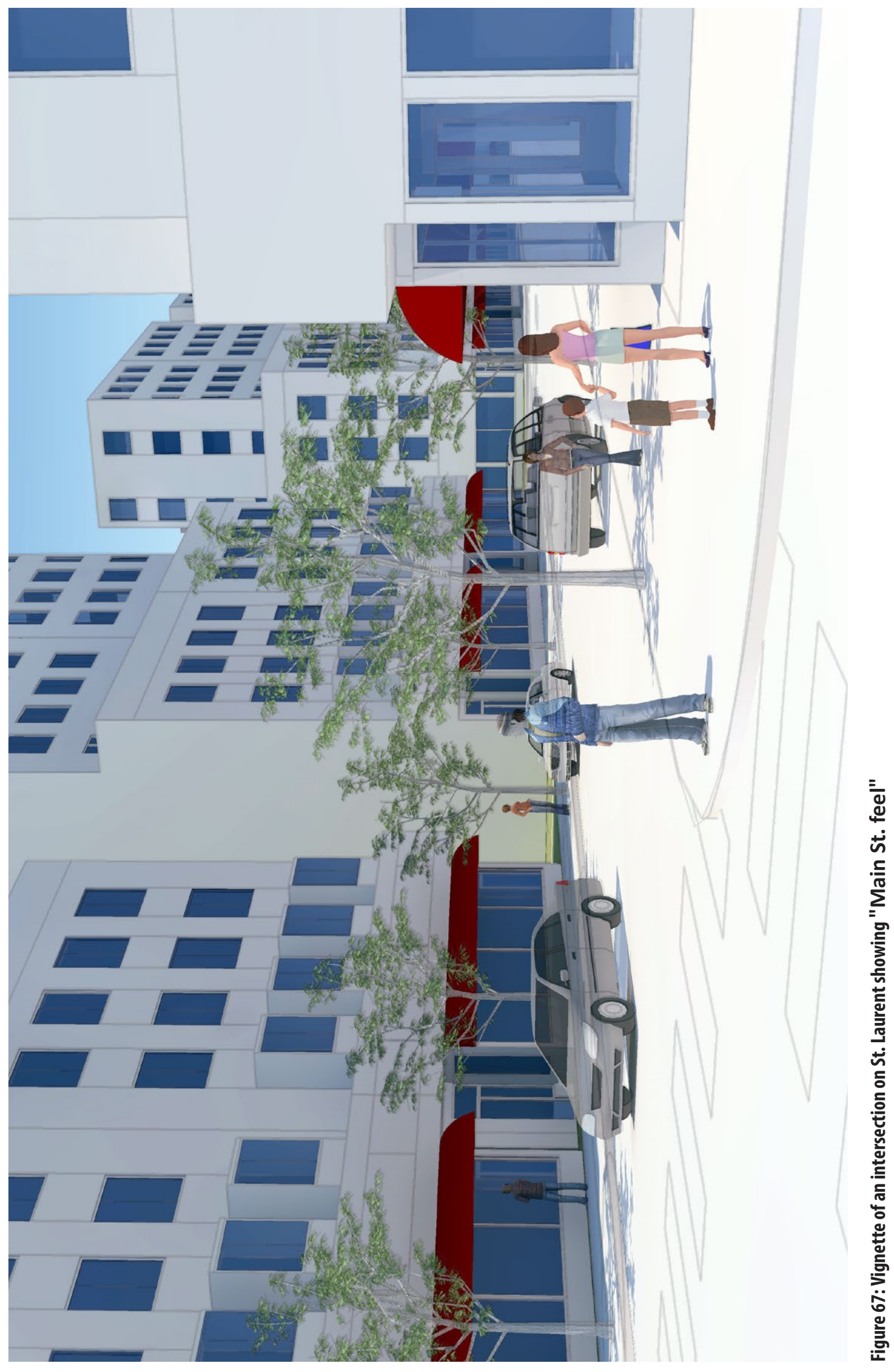


energy system such as the one pioneered at Drake Landing in Okotoks, Alberta, ${ }^{31}$ could dramatically reduce the neighbourhood's dependence on fossil fuels, thus increasing its overall environmental sustainability. In combination with solar panels on the new buildings (discussed below), geo-thermal bore holes below the landscaped areas around the community center would store solar heat throughout the year to assist in heating homes during the winter.

Envisioned as a 'main street,' (Fig. 67) St. Laurent Blvd. will connect the community center to the mixed-use plaza on the southeast corner of St. Laurent and Hemlock. Together, the plaza and the center are envisioned as destination anchors along a vibrant stretch of street. Buildings along this portion of St. Laurent will accommodate commercial at grade with residential above. Like the DPZ neighbourhood diagram, the intent is that primarily neighbourhood-scaled shops be accommodated north of Hemlock (recall that the area south of Hemlock has been recommended for national retailers). The height limit has been increased from six to eight storeys, with appropriate setbacks, to achieve the densities required to make the commercial feasible. Towers are strategically placed to create landmarks at key points, and their scale relates to, but is less than, existing towers in the southern portion of Manor Park (just North of Montreal Rd.).

While typical residential blocks are 230' $(70 \mathrm{~m})$ deep, the blocks to the west of St.
Laurent have been designed at a depth of $254^{\prime}(77.5 \mathrm{~m})$ feet to accommodate the deeper floorplates necessary for retail and public parking for customers. Opposite the commercial, along Estate street, four-and-ahalf-storey walk-ups help make a transition in scale, following Carver's suggestion of combining small stores with multi-family housing in such a way as to, "Conceal the service yard and parking space." ${ }^{32}$ While the buildings are meant to serve a very specific purpose, they also provide a modern living accommodations discussed below.

\section{Housing and Tenancy Options}

An appreciation of the surrounding residential fabric was key to determining building heights, types and residential densities. The duplexes on Braemar St. approximate the scale of the single-family dwellings along the northern stretch of the street (Fig. 68). To their east the scale increases gradually to a height of eight storeys along St. Laurent, with the inclusion of low-rise housing in one of three configurations described below. The scale increases again to five-and-a-half storeys along the new "Estate Street," where a new form of mid-rise housing bridges between the residential and mixed-use areas. Across St. Laurent the massing decreases again to an area of primarily stacked town houses in keeping with what currently exists in that area.

The residential buildings along Estate Street combine townhouses at grade with 


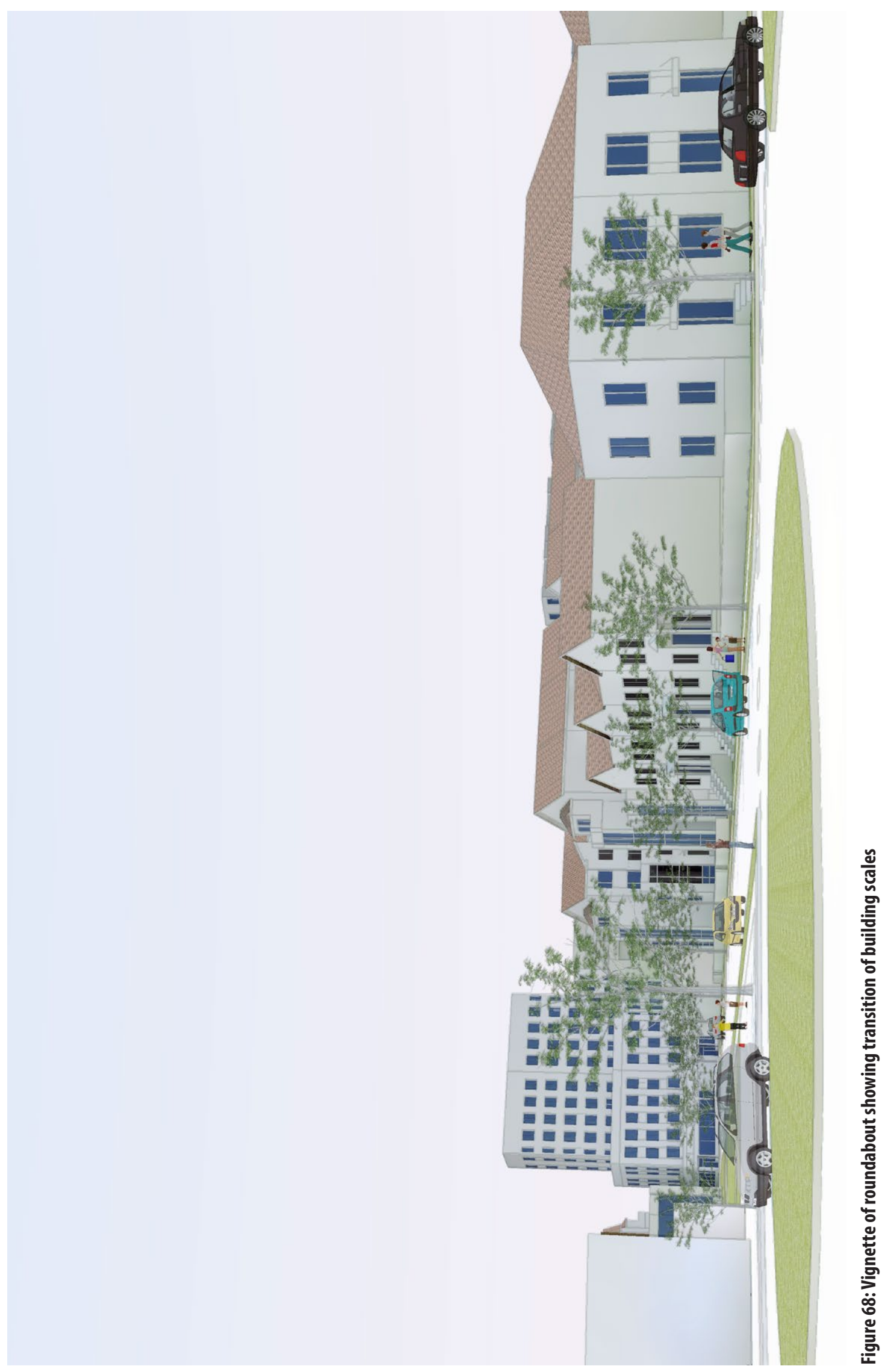


slightly smaller, one-and-a-half-storey condos above, accessed via a shared corridor (Fig. 69 - 70). Although a relatively new housing form, a similar building type was recently included in the Claridge development at Lebreton Flats, Ottawa. There is every possibility that they will be well received in the real-estate market, particularly by young professionals who have limited budgets and space requirements.

The proposed grid for MPE accommodates three different options for the housing on the residential blocks to the west of Estate St (Fig. 71 - 73). The first (and simplest) option is town houses with stacked flats above, with breezeway parking behind. (Breezeways are recommended following the example of Drake Landing as they provide a surface upon which to attach solar panels required for the solar thermal district heating system mentioned above, as well as aiding to reduce the heat island effect associated with large parking surfaces. ${ }^{33}$ ) A second option is to maintain the same density with more diversity of unit types by incorporating townhouses with laneway housing on alternating lots. Properties without laneway houses could include income suites in the upper or lower level of the townhouse. A third option is to provide single-family dwellings with laneway housing. While this option is the least dense, it might appeal the most to the community as the form (single-family dwelling) is most in character with the neighbourhood. Any one of these options would work for Manor Park, and they all work together with the housing

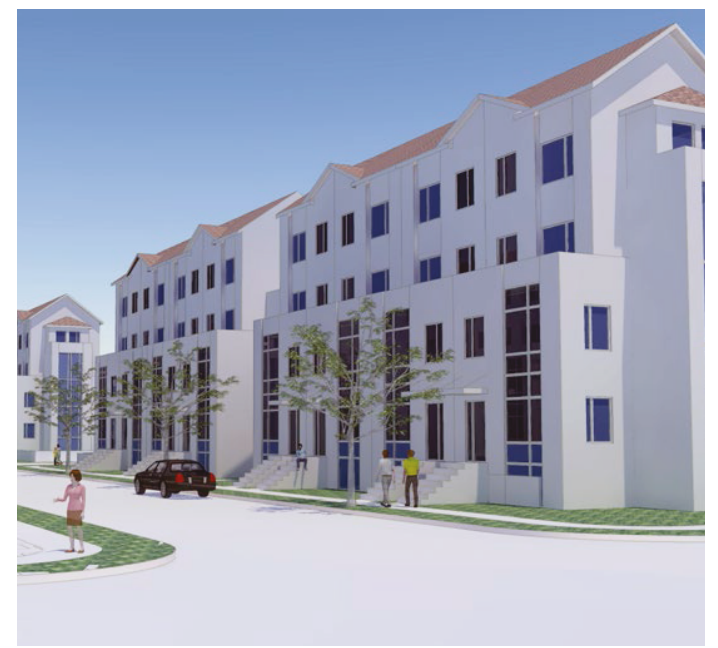

Figure 69: Vignette Estate St. walk-ups

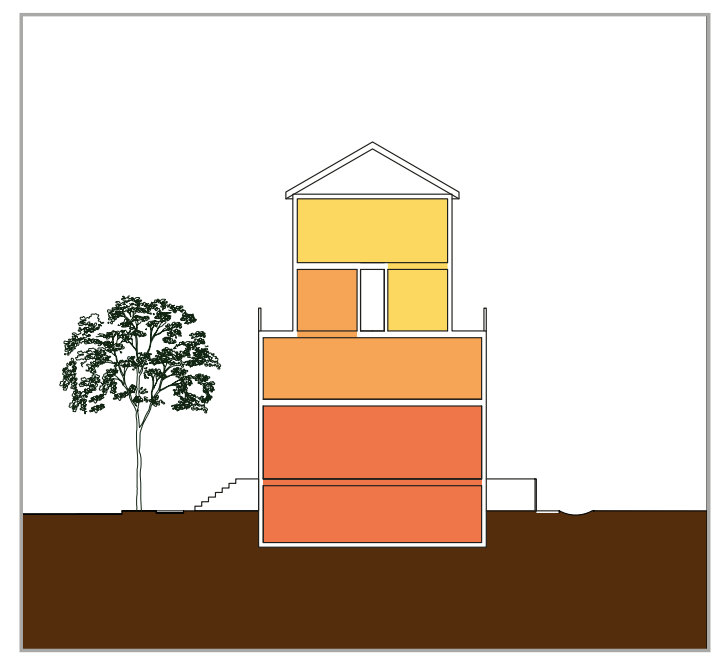

Figure 70: Section showing units in Estate St. walk-ups 
in other areas of the design to create a variety of types, both in terms of size and configuration, enabling residents to select housing that best suits their circumstances.

The various housing forms in the demonstration plan also support multiple tenancy options. The duplexes and townhouses lend themselves to freehold ownership while the stacked towns and mid-rises could be organized as condominiums. The residential units above the commercial along St. Laurent could accommodate either rental or condo ownership. All of these tenancy types can be related to the original design of Manor Park, which included both freehold and rental options. Meanwhile the condo designation, a more recent creation, can be related to the historical Cape Cods inasmuch as condos have become the starter homes of the $21^{\text {st }}$ century.

\section{Stormwater Management}

Following High Point's example, the control of stormwater figures prominently in the proposed re-design of MPE. The majority of rainfall will be managed directly on site through the use of bioswales along the edges of all parking lots. Additionally, green roofs will be incorporated into the design of institutional and mixed-use buildings. As mentioned above, a key stormwater management strategy is a retention pond in the new community park. While calculations are based on rules of thumb, ${ }^{34}$ the implementation of these solutions will not only prevent increased demand on the municipal

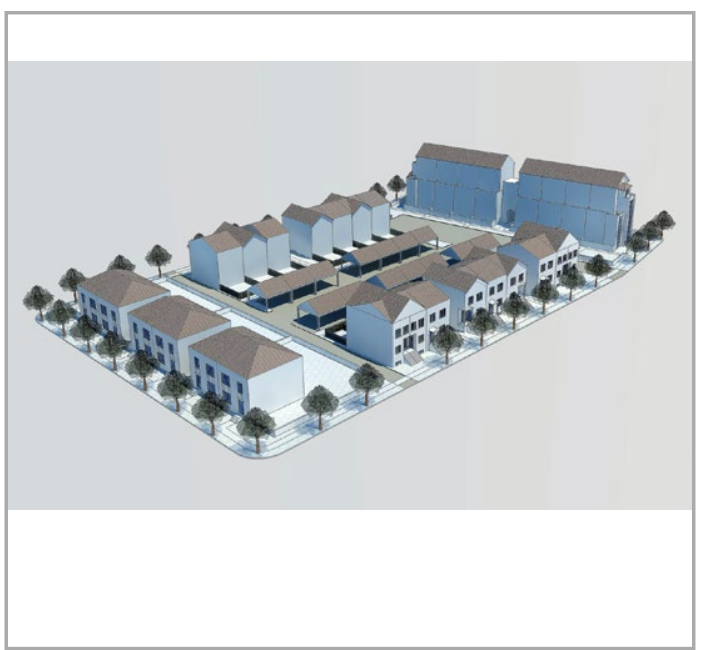

Figure 71: Diagram of residential Option 1

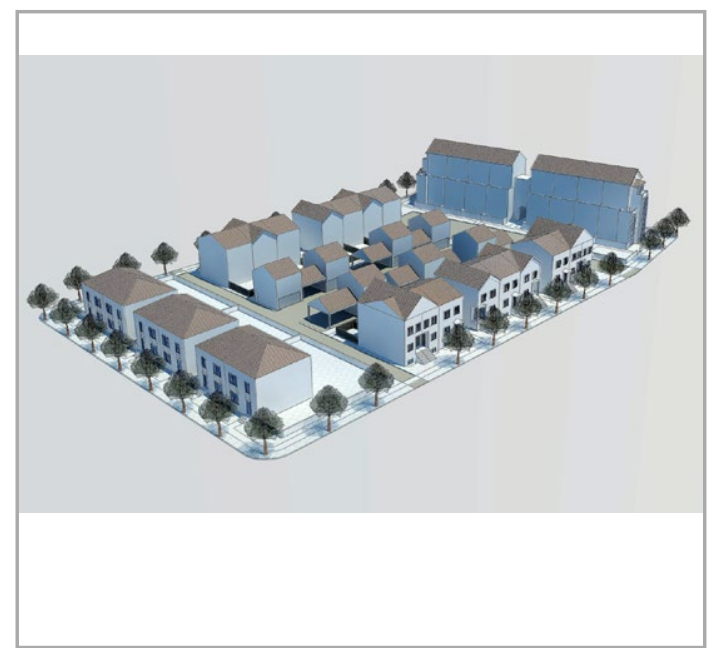

Figure 72: Diagram of residential Option 2

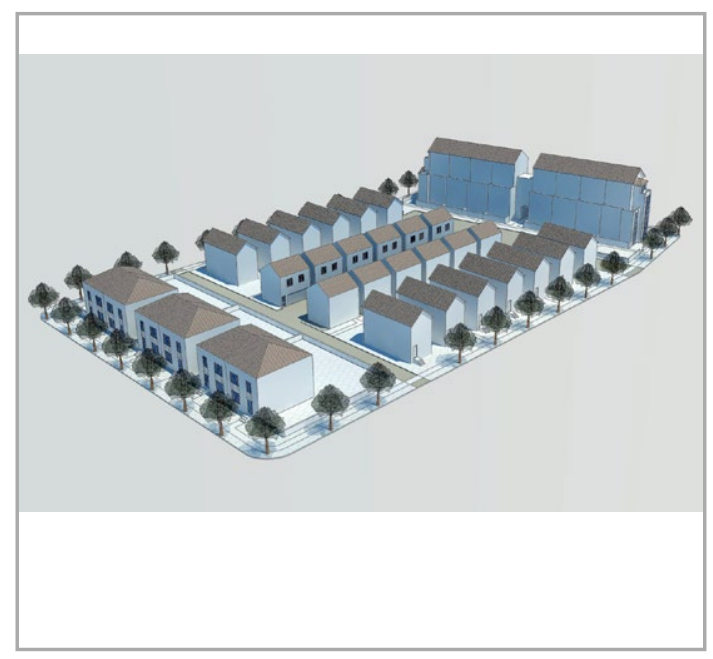

Figure 73: Diagram of residential Option 3 
stormwater system, but will likely reduce levels below existing demand.

\section{Green Nodes and Pathways}

The demonstration plan includes two new parks, one large (adjacent to the community centre) and the other small (within Mart Circle). These parks complement the existing open spaces in the area. A pedestrian pathway system adds another level of connectivity and enhances the relationship between these various green spaces. (Fig. 74) Meanwhile provision of bike paths along both Hemlock Rd. and Laurent Boulevard encourage alternate modes of transportation by connecting to existing pathways along Aviation Parkway (and to CFB Rockcliffe development beyond) and along Ottawa River.

\section{Green Infrastructure}

Although beyond the scope of this design, it is recommended that all new buildings associated with the intensification of MPE be built to higher standards than required by the building code, ideally attaining a LEED certification. Each building should strive to be as energy-and water efficient as possible as this will reduce operating costs as well as the environmental impact of the neighbourhood as a whole.

\section{Conclusion}

Following an analysis of the of the issues at play in Manor Park, the demonstration plan creates a roadmap for the intensification of the neighborhood that synthesises current ideas on sustainability and urban planning. As seen in figure 78 , the demonstration plan for Manor Park strongly resembles to the neighbourhood unit in all of its configurations (Fig. 75 - 77); a hybrid of all three. While key components, such as the location of the school and large areas of single-family dwellings, were incorporated in the initial construction, others are a result of the proposed intensification of the area. Figure 78 shows how the proposed Manor Park neighbourhoods, shown within circles

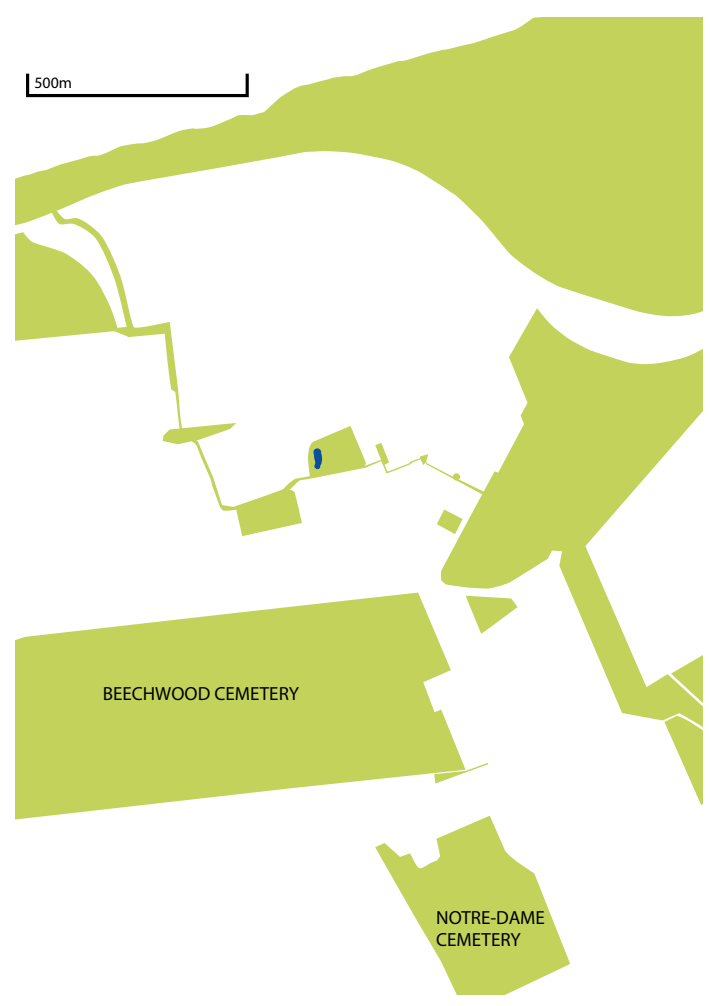

Figure 74: Diagram of parks and pathways 
of an approximately 15-minute walk (larger than Perry's neighbourhood unit) reincorporate the mix of uses along the arterial (St. Laurent) that was recommended by Perry, and conceived of, but not built, in Manor Park. The addition of commercial spaces is expected to become viable due to the additional density resulting from the redevelopment of Manor Park Estates through a diversity of housing types and sizes. Park spaces remain important in the Manor Park plan as additional parks complement existing green spaces. Following the DPZ neighbourhood plan, the street layout has been altered where possible to create a more interconnected street grid. As Farr associates have done, environmental concerns have been addressed through the addition of stormwater boulevards, bioswales and a retention pond, as well as the inclusion of high-performance infrastructure such as a combination solar-geothermal district energy plant. The idea that implicit within post-war suburbs is a roadmap for their own in intensification is a compelling one. The result is closely related to the neighbourhood unit as proposed by both DPZ and Farr Associates. Again, this is appropriate inasmuch as the original neighbourhood was informed by Perry's diagram

\section{Notes}

1. Carver, Humphrey. Houses for Canadians; A Study of Housing Problems in the Toronto Area University of Toronto Press, 1948, 23.

2. See http://www.mah.gov.on.ca/Page1485.aspx, accessed Jul 11, 2013.

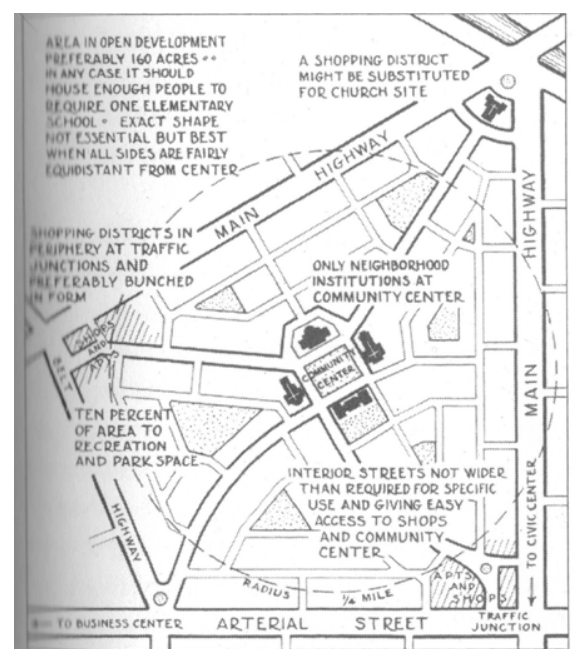

Figure 75: Perry Neighbourhood Diagram

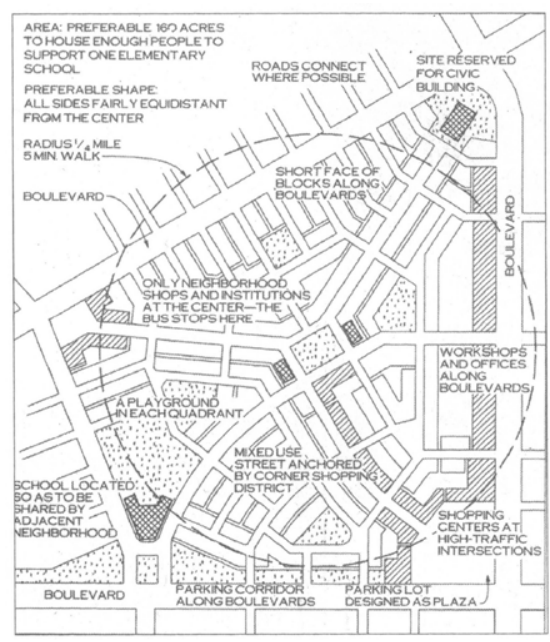

Figure 76: DPZ Neighbourhood Diagram

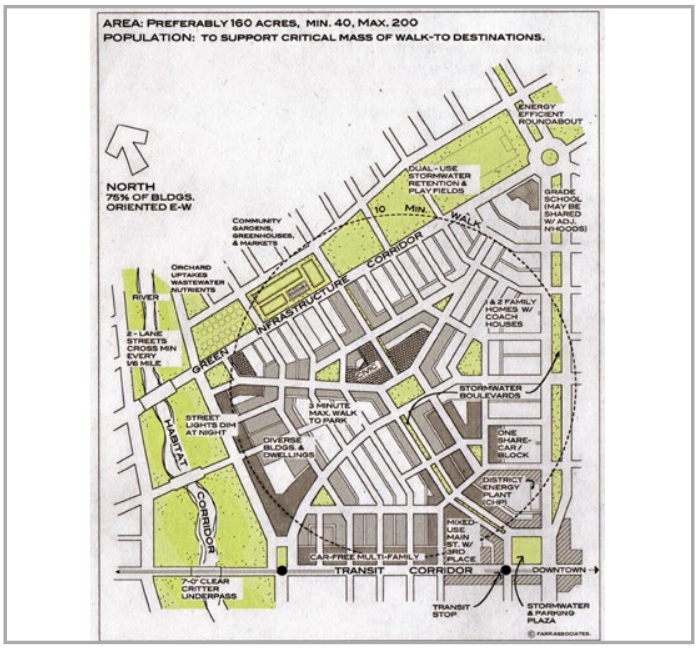

Figure 77: Farr Neighbourhood Diagram 


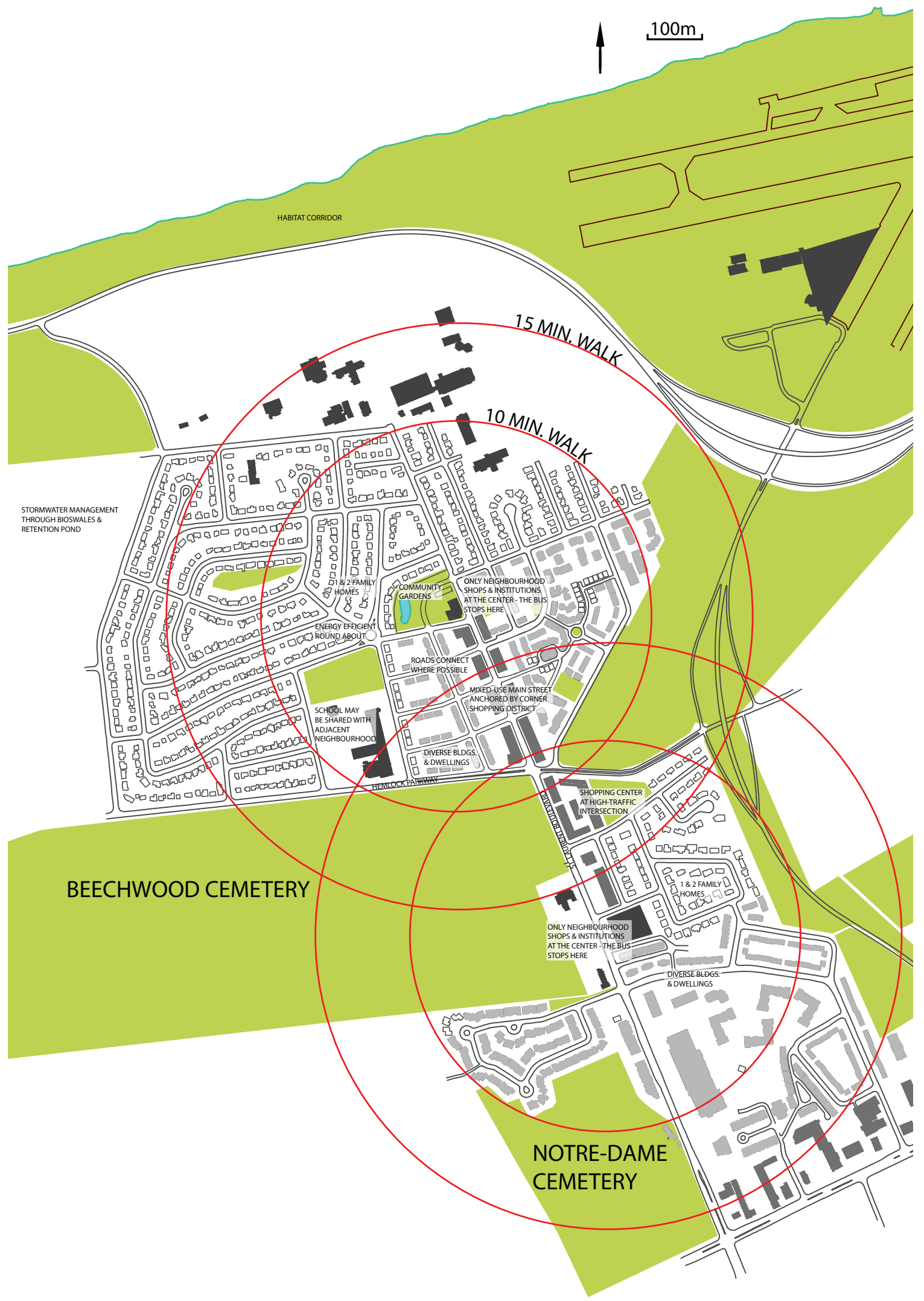

Figure 78: Manor Park neighbourhoods diagram 


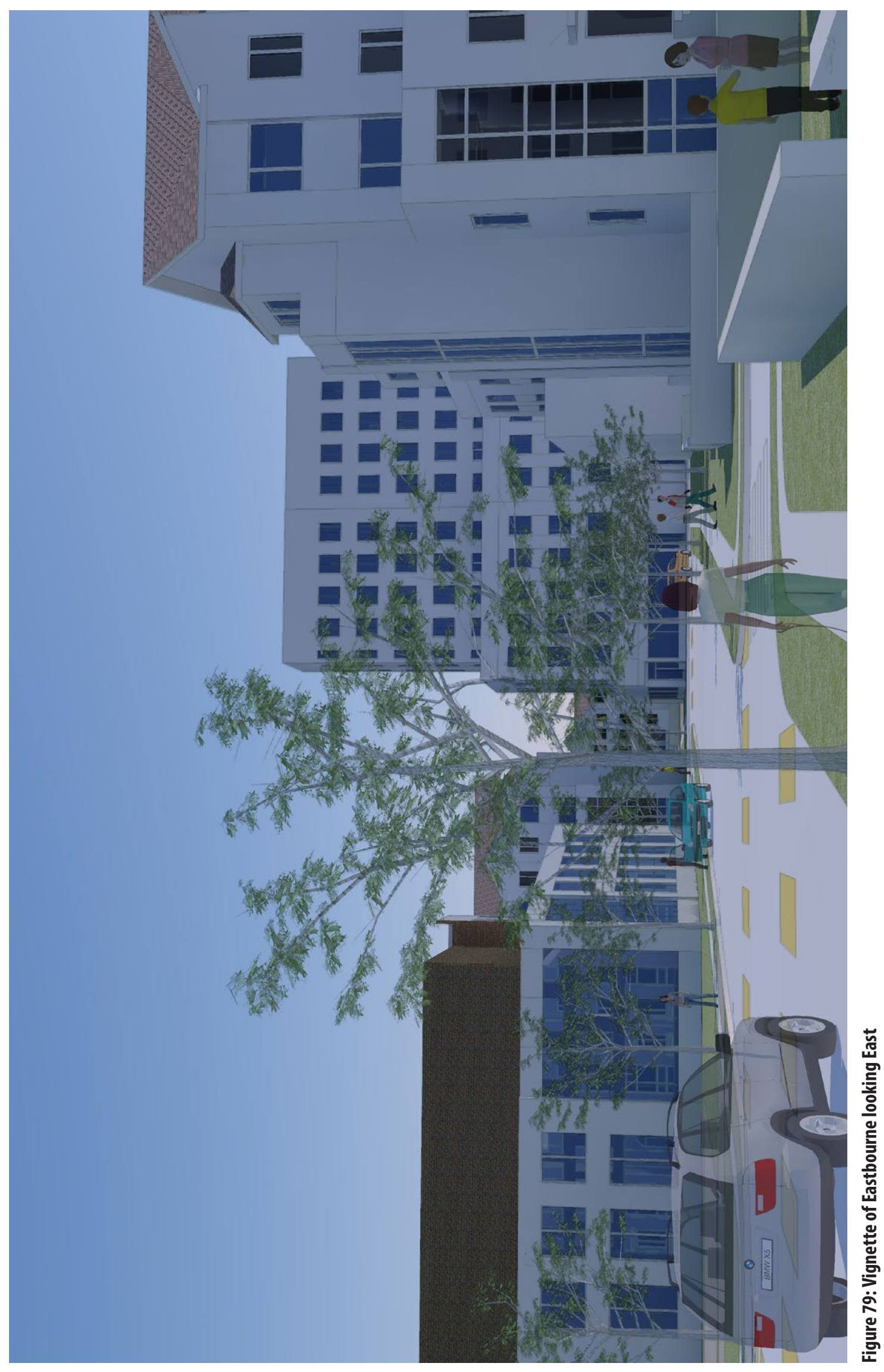


3. "City of Ottawa Official Plan; 2.2 Managing Growth." City of Ottawa. http://ottawa.ca/en/officialplan-0/22-managing-growth (accessed April 12, 2013).

4. "Complete Streets for Canada; Policy and Design Hub for Building Safe and Inviting Streets for all." Toronto Center for Active Transportation. http:// completestreetsforcanada.ca/what-are-completestreets (accessed July 14, 2013).

5. "Complete Streets for Canada" Toronto Center for Active Transportation. http:// completestreetsforcanada.ca/what-are-completestreets (accessed July 14, 2013).

6. "Transportation Master Plan; Ch. 3 Strategic Directions." City of Ottawa Strategic Planning Unit Infrastructure Services and Community Sustainability Dept.http://app06.ottawa.ca/cs/groups/content/@ webottawa/documents/pdf/mdaw/mti2/ edisp/ cap126406.pdf (accessed July 14, 2013, 2013).

7. Ibid.

8. "City of Ottawa Official Plan; 2.2 Managing Growth." City of Ottawa. http://ottawa.ca/en/officialplan-0/22-managing-growth (accessed April 12, 2013).

9. "Former CFB Rockcliffe Lands." Canada Lands Company. http://www.clc.ca/properties/ rockcliffe (accessed July 4, 2013).

10. Nash, Michelle. "Plans for Former Rockcliffe Air Base Shaping Up." Ottawa West News, June 6, 2013, sec. Business directory.

11. "City of Ottawa Official Plan; 1.4 Ottawa's Growth Management Plans." City of Ottawa. http://ottawa.ca/en/volume-1official-plan/14-ottawas-growth-managementplans (accessed April 12, 2013).

12. "City of Ottawa Official Plan; 2.2 Managing Growth." City of Ottawa. http://ottawa.ca/en/officialplan-0/22-managing-growth (accessed April 12, 2013).

13. Dunham-Jones, Ellen and June Williamson. Retrofitting Suburbia; Urban Design Solutions for Redesigning Suburbs. Hoboken, New Jersey: John Wiley \& Sons, Inc., 2009, 5 and 53.

14. Lukez, Paul. Suburban Transformations. New York: Princeton Architectural Press, 2007, 36.

15. Dunham-Jones and Williamson. Retrofitting Suburbia, 20.
16. Ibid., 19.

17. "[High Point] Redevelopment Plan." Seattle Housing Authority. http://www.seattlehousing.org/ redevelopment/high-point/plan/ (accessed June 5, 2013).

18. Sewell. Houses and Homes, 43.

19. Marshall, Alex, How Cities Work, Austin, University of Texas Press, 2000, 12.

20. Ritchie, Adam and Thomas, Randall, Sustainable Urban Design, Oxon: Taylor and Francis, 2009, 181.

21. Duany, A, Plater-Zyberk, E and Speck, J., Suburban Nation, North Point Press; First Edition (April 16, 2001).

22. Dunham-Jones and Williamson. Retrofitting Suburbia, 5.

23. Farr, Douglas. Sustainable Urbanism; Urban Design with Nature. Hoboken, New Jersey: John Wiley \& Sons, Inc, 2008, 234.

24. "Best Practices in Affordable Housing: Seattle's High Point Redevelopment Project." U.S. Department of Housing and Urban Development. http://www. huduser.org/portal/bestpractices/study 040920121. html (accessed July 4, 2013).

25. The process whereby the least desirable housing falls to those least able to afford it.

26. "LEED for Neighbourhood Development." U.S. Green Building Council. https://new.usgbc.org/leed/ rating-systems/neighborhoods (accessed Nov. 6, 2012), 58.

27. Farr. Sustainable Urbanism, 234.

28.

"City of Ottawa Official Plan; 5.2.2 - Stormwater Management Policies." City of Ottawa. http://ottawa.ca/en/city-hall/planning-and-development/ official-and-master-plans/infrastructure-master-plan/ section-5/-1 (accessed July 12, 2013).

29. Ferguson, Abner. Successful Subdivisions; Planned as Neighbourhoods for Profitable Investment and Appeal to Home Owners. Land Planning Bulletin no. 1., edited by Federal Housing Administration. Washington, D.C.: U.S. Government Printing Office, 1941, 15.

30. "LEED for Neighbourhood Development." U.S. Green Building Council. https://new.usgbc.org/leed/ rating-systems/neighborhoods (accessed Nov. 6, 2012), 67. 
31. "District Energy Warms Up Alberta's Suburbs." FCM Community Energy Planning Mission. http:// www.fcm.ca/Documents/presentations/2007/

mission/District energy warms up Albertas suburbs EN.pdf (accessed July 6, 2013).

32. Carver, Humphrey. Cities in the Suburbs University of Toronto Press, 1965, 81.

33. "LEED for Neighbourhood Development." U.S. Green Building Council. https://new.usgbc.org/leed/ rating-systems/neighborhoods (accessed Nov. 6, 2012), 95 .

34. Farr. Sustainable Urbanism, 178. 


\section{Chapter 5 Post-Script}

This thesis addresses a number of the challenges and opportunities associated with the intensification of established, low-density suburban neighbourhoods. Informed by an understanding of their history, the forces now acting on them, and current thinking on sustainable urban design, the thesis explores approaches to transformation that not only don't threaten, but enhance the existing social stability and architectural character of these neighbourhoods.

Where history is concerned, a literature review of post-war suburbanization in North America, broadly, and of Ottawa's Manor Park, specifically, provided a basis for understanding how diverse factors affect the shape of our urban environment. Meanwhile, a review of sustainable design and precedents for suburban intensification offered insight into current directions, guiding the decisions taken in the design portion of the investigation. Design, itself, formed an integral part in the research. The demonstration plan for Manor Park was the result of an iterative design process - in which the precedents, practices, targets and standards identified in the review of literature were tested against the existing patterns and character of the neighbourhood.

In producing the demonstration plan of
Manor Park I took the role of an external designer, without bias toward existing landowners, residents, community associations, etc. The next step, of course, would be to present the plan to these stakeholders, to City staff, the ward councillor and relevant members of the development community (in particular Domicle and LA Group Construction, who are developing projects nearby). Based on their feedback, successive iterations would be generated. While the idea of producing a design in advance of extensive community consultation may seem misguided, I see the demonstration plan as an important means of soliciting feedback, not simply the result of such feedback. City of Ottawa planner Randolph Wang contends that "an urban design process is only as valid as the number of stakeholders that have been consulted." I believe that he is correct, in that a true urban design process draws its validity from the participation of as many stakeholders as possible, from landowners, to residents, to neighbourhood associations and business owners. Were I to continue with the research, then, the next step would involve consultation with exactly these groups, both to gauge the level of interest in creating a redevelopment plan for the area and to solicit feedback on the form of the redevelopment. In this respect the demonstration 
plan described in Chapter 4 represents an informed point of departure, a tool for generating meaningful discussions among area stakeholders. Such discussions could even be formalized as a City-led Community Design Plan process, as is currently underway for the adjacent Rockcliffe Air Base property. It is fully expected that the proposed demonstration plan would undergo additional revisions and iterations as a result of the consultation process.

As the Manor Park Community Association (MPCA) has identified a need for a community plan, ${ }^{1}$ it is my hope that the neighbourhood would welcome this kind of collaboration. Indeed the MPCA web site observes that:

"Watching the group of residents from Manor Park Hill work diligently in conjunction with MPCA to react to a project underway made us realize that having something proactive and available for discussions with prospective developers and business people could be a critical tool for residents and community developers." ${ }^{2}$

Had this been a real project rather than a theoretical study, it might have been prudent to involve the community at an earlier stage, to better assess their needs and desires as well as their perspective on potential changes. Although I discovered the community's interest in developing a community design plan late in the design process, the demonstration plan adheres to many of the core principles established by the MPCA, including, "conservation of the natural environment, heritage, and character of the community and ... taking into account relevant social, economic and environmental matters." ${ }^{3}$

If and when a redevelopment were accepted by the stakeholders, the process could unfold in a number of different ways. Agarwal Sarinder, the owner of Manor Park Estates, could either choose to develop the land in its entirety or sell the land to another developer to develop. Alternatively, Sarinder (or another developer) could lay out the new street grid, coordinate improvements, then parcel off individual blocks, or lots, to different developers (keeping in mind that any redevelopment should be phased carefully to cause the least disruption possible to the existing residents).

While the demonstration plan is only one of many possible alternatives for the redevelopment of the Manor Park area (Fig. 80 - 82), its viability (as a point of departure) is defensible inasmuch as it is consistent with strategies of neighbourhood planning deployed in suburban redevelopments such as Mapleton and High Point. These include 1) the subdivision of large, low-density parcels by means of a connected street grid, 2) intensification of the site with a diversity of building types and uses appropriate to the community, 3) the creation of parks and open spaces that are easily accessible to residents, and 4) the incorporation of green infrastructure such as stormwater management and renewable 
energy sources. Also contributing to the potential success of the demonstration plan is its overall flexibility. As noted, there are at least three options for the build-out of residential blocks, all of which meet the redevelopment goals, and most of the building types are flexible enough to adapt to changing markets and housing preferences. In part this flexibility is built into the neighbourhood unit, on which both the original and proposed development are based.

Indeed the adaptability of the neighbourhood unit may be key to the redevelopment of many of the early post-war suburbs poised to intensify due to their favourable location, to changing demographics and to government policies that favour intensification. While the forces acting on and influencing urban planning have evolved over the years, Clarence Perry's neighbourhood unit continues to be both relevant and influential. There are a number of reasons for this: 1 ) its quarter mile radius locates a variety of uses within walking distance of homes (although in existing neighbourhoods the radius is often larger), 2) it provides a range of housing options at a density that will support commercial (although this was not incorporated in post-war suburbs, recent increases in density targets take us full circle to what Perry originally recommended), 3) its clearly defined edges and center create an identifiable neighbourhood unit that can be applied in building block fashion and with which residents can connect. Recent adaptations have aligned streets across arterials for improved

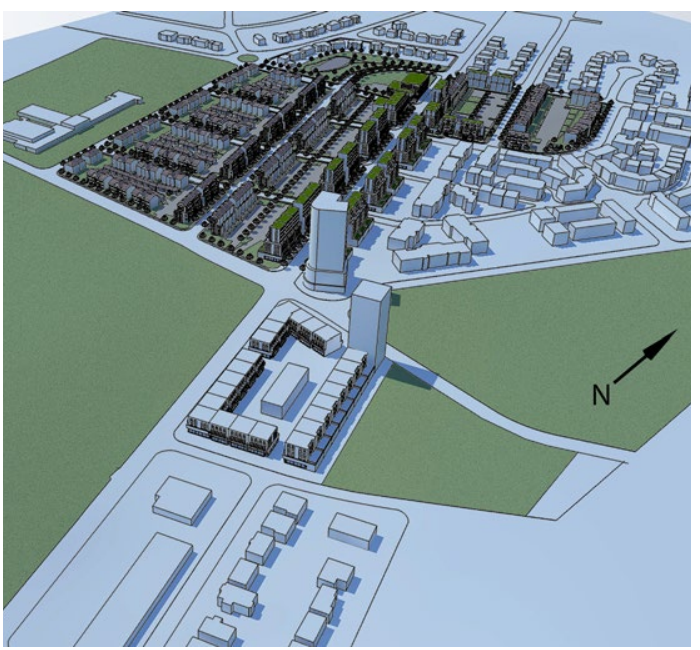

Figure 80: Aerial view showing alternate location for towers

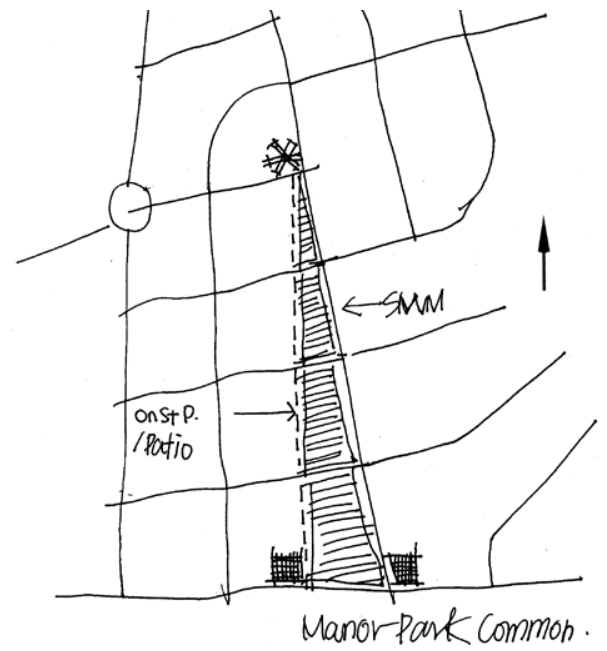

Figure 81: Alternate parti showing continuous parkland along St. Laurent Blvd

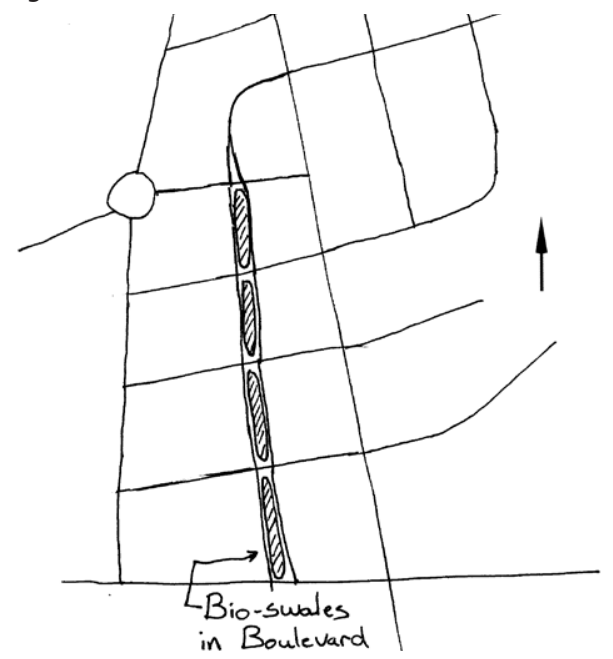

Figure 82: Alternate parti showing development of a linear park storm water management along Estate St. 
circulation between neighborhoods, shifted the primary school from the core to an edge in recognition of changes in demographics, and have added a layer of environmental consciousness. Motivated, in part, by the desire to determine if redevelopment can enable an established neighbourhood to be more like it was originally intended to be, I have determined that the neighbourhood unit may be utilized as a framework for analysing and adapting mature neighbourhoods.

\section{Notes}

1. "Manor Park Community Council; Future Development." Manor Park Community Council and Manor Park Community Association. http:// www.manorpark.ca/pages/neighbourhood/ development/ (accessed April 13, 2013).

2. Ibid.

3. "Manor Park Community Council; Future Development." Manor Park Community Council and Manor Park Community Association. http:// www.manorpark.ca/pages/neighbourhood/ development/ (accessed April 13, 2013). 


\section{$\frac{\text { Appendices }}{\text { List of Illustrations }}$}

- Figure 1: Perry Neighbourhood Unit, $1929 \quad 13$

Farr, Douglas. "Sustainable Neighbourhoods." In Sustainable Urbanism; Urban Design with Nature. Hoboken, New Jersey: John Wiley \& Sons, Inc, 2008, 125.

- Figure 2: Radburn Community Plan 14

Stein, Clarence S., "Radburn." Chap. 2, In Toward New Towns for America. Third ed., 37-74. (Cambridge, Massachusetts: The M.I.T. Press, 1969), 50.

- Figure 3: Radburn Neighbourhood Plan 14

Sewell, The Shape of the City, 38.

- Figure 4: Plan of Ajax, Ontario 14

Sewell, John. The Shape of the City: Toronto Struggles with Modern Planning. Toronto, Canada: University of Toronto Press Incorporated, 1993, 77.

- Figure 5: Plan of Radburn as completed, in 1930

Stein, 49.

- Figure 6: Aerial view of Levittown under construction 16

Kelly, Barbara M. Expanding the American Dream; Building and Rebuilding Levittown. (Albany, N.Y.: State University of New York Press, 1993), 152.

- Figure 7: FHA diagram recommending streets follow topography 17

Ferguson, Abner. Successful Subdivisions; Planned as Neighbourhoods for Profitable Investment and Appeal to Home Owners. Land Planning Bulletin no. 1., edited by Federal Housing Administration. Washington, D.C.: U.S. Government Printing Office, 1941, 15.

- Figure 8: Architects rendering of Levittown Cape Cod and Floor plan of Cape Cod by Kelly, Barbara M. 17

Kelly, 67.

- Figure 9: Architects rendering of Levittown ranch models 1949-51 18 Kelly, 43.

- Figure 10: Don Mills Plan 19 Sewell, The Shape of the City, 87.

- Figure 11: Map locating Manor Park area in Ottawa 26

By author 
- Figure 12: Map from 1911 locating Manor Park site in relation to existing roads 27

Nagy, Thomas. Ottawa in Maps; A Brief Cartographical History of Ottawa 1825-1973. National Map Collection., edited by Public Archives Canada. Ottawa: Information Canada, 1974, 37, edited by author

- Figure 13: Architects rendering of Manor Park `Semi-Bungalow` design 28

"Ontario's Newest Community Housing Plan." Canadian Homes \& Gardens (September, 1947): 27.

- Figure 14: Architect's rendering of 'One-and-a-Half Storey Cape-Cod' design 28

"Ontario's Newest Community Housing Plan." Canadian Homes \& Gardens (September, 1947): 26.

- Figure 15: Architects rendering of Manor Park 'Two-Story Modernized Colonial' design 28

"Ontario's Newest Community Housing Plan." Canadian Homes \& Gardens (September, 1947): 28.

- $\quad$ Figure 16: Architects rendering of Manor Park shopping center 29

“Ontario's Newest Community Housing Plan." Canadian Homes \& Gardens (September, 1947): 32.

- Figure 17: Plan analysis of Manor Park`s design development 31

Compiled by author from various sources

- Figure 18: Analysis of Manor Park Neighbourhood as built 32

By author

- Figure 19: Recent and upcoming development projects in the Manor Park area 34

By author

- Figure 20: Manor Park Estates 35

By author

- $\quad$ Figure 21: Photo of typical row houses in MPE 36

By author

- Figure 22: Unit plans of Manor Park Estates from 1950s promotional material 36

Manor Gardens in Manor Park Village Ottawa; Canada's most Beautiful Garden Dwellings. Ottawa, Ontario: Manor Gardens Ltd., 1950.

- Figure 23: Triple-Bottom-Line diagram 39

"SustainVU." Vanderbilt University. http://www.vanderbilt.edu/sustainvu/who-weare/what-is-sustainability/ (accessed Aug. 8, 2013).

- Figure 24: Smart growth principles

40

Farr, 30, recreated by author 
- Figure 25: DPZ Neighbourhood Diagram

By author

- Figure 26: Farr Neighbourhood Diagram

Farr, 125.

- Figure 27: Diagram locating Mableton in relation to Atlanta

Farr, 126.

- Figure 28: Plan of existing conditions in Mableton

44

"Duany Plater-Zyberk and Company; Mableton, Georgia, USA." Duany Plater-

Zyberk. http://www.dpz.com/Practice/1003 (accessed May 18, 2013).

- Figure 29: Plan of proposed streets for Mableton

44

Duany Plater-Zyberk. http://www.dpz.com/Practice/1003 (accessed May 18, 2013).

- Figure 30: DPZ`s Illustrative Masterplan of Mableton 44

Duany Plater-Zyberk. http://www.dpz.com/Practice/1003 (accessed May 18, 2013).

- Figure 31: Existing conditions at intersection of Floyd and Clay 45

Duany Plater-Zyberk. http://www.dpz.com/Practice/1003 (accessed May 18, 2013).

- Figure 32: DPZ`s vision for Floyd and Clay 45

Duany Plater-Zyberk. http://www.dpz.com/Practice/1003 (accessed May 18, 2013).

- Figure 33: Community node at "Barnes Homestead" 45

Duany Plater-Zyberk. http://www.dpz.com/Practice/1003 (accessed May 18, 2013).

- Figure 34: Diagram locating High Point in Seattle

46

By author

- Figure 35: Photograph of High Point under construction showing housing forms46

"[High Point] Photos." Seattle Housing Authority. http://www.seattlehousing.org/ redevelopment/high-point/photos/ (accessed June 7, 2013).

- Figure 36: Photograph of High Point before demolotion 46

Seattle Housing Authority. http://www.seattlehousing.org/redevelopment/highpoint/photos/ (accessed June 7, 2013).

- Figure 37: Historic street plan in High Point 47

By author, based on Office of the Seattle City Clerk. Seattle - High Point Map. Vol. Seattle City Clerk's Neighborhood Map Atlas 2011-04-23.

- Figure 38: Modified street plan in High Point 47

By author, based on Farr, 235

- $\quad$ Figure 39: Table showing breakdown of unit types at High point47

"[High Point] Redevelopment Plan." Seattle Housing Authority. http://www.seattlehousing.org/redevelopment/high-point/plan/ (accessed June 5, 2013). 
- Figure 40: Street section showing High Point bioswales

Farr, 236

- Figure 41: Manor Park development potential 53

By author

- Figure 42: Table comparing existing and proposed figures for the Manor Park Estates demonstration plan $\quad 55$

By author

- Figure 43: Table showing breakdown of unit types proposed in the Manor Park demonstration plan 57

By author

- $\quad$ Figure 44: Manor Park figure-ground analysis 59

By author

- Figure 45: Manor Park natural features 59

By author

- Figure 46: Manor Park existing circulation and block size

60

By author

- Figure 47: Manor Park proposed circulation and block size

60

By author

- Figure 48: Zoning reference table

61

By author, based on "Interpreting Zonning Information." City of Ottawa. http:// ottawa.ca/en/residents/laws-licenses-and-permits/laws/city-ottawa-zoning-law/ zoning-law-2008-250-consolidation--1 (accessed Jan., 2013).

- Figure 49: Manor Park zoning map

62

By author, based on "GeoOttawa." City of Ottawa. http://maps.ottawa.ca/geoOttawa/ (accessed Jan., 2013).

- Figure 50: Diagram of broad strokes including new comunity centers and shopping node $\quad 64$

By author

- Figure 51: Aerial view of demonstration plan from south

65

By author

- Figure 52: Aerial view of demonstration plan from north

By author

- Figure 53: Photograph of Duke of York Square 65

Deveney, Alicia. "Duke of York Square." The London Magazine (Apr. 22, 2010, : June 2013, http://www.thelondonmagazine.co.uk/Local-London/More-Local-London/ Duke-of-York-Square.html, edited by author. 
- Figure 54: Illustration of Duke of York Square 65

Deveney, Alicia. "Duke of York Square." The London Magazine (Apr. 22, 2010, : June 2013, http://www.thelondonmagazine.co.uk/Local-London/More-Local-London/ Duke-of-York-Square.html, edited by author.

- Figure 55: Rendering of commercial on market day

By author

- Figure 56: Large scale new street plan diagram 67

By author

- Figure 57: Diagrams of street grid options tested

By author

- Figure 58: Street sections 69

By author

- Figure 62: Current photo of rear of rental court70

By author

- Figure 59: Plan showing potential historic fragment $\quad 70$

By author

- Figure 60: Current photo of rental court70

By author

- Figure 61: Rendering from 1950 rental brochure

70

Manor Gardens in Manor Park Village Ottawa; Canada's most Beautiful Garden Dwellings. Ottawa, Ontario: Manor Gardens Ltd., 1950.

- Figure 63: Proposed plan for Manor Park Estates

71

By author

- Figure 64: Parti diagram showing proposed park and commercial nodes, connected by a mix of uses along St. Laurent Blvd. 72

By author

- Figure 65: Vignette of towers at Hemlock and St. Laurent 72

By author

- Figure 66: Large scale plan of park node

72

By author

- Figure 66: Large scale plan of park node

By author

- Figure 67: Vignette of an intersection on St. Laurent showing "Main St. feel" 73

By author

- Figure 68: Vignette of roundabout showing transition of building scales 75

By author 
- Figure 69: Vignette Estate St. walk-ups 76

By author

- Figure 70: Section showing units in Estate St. walk-ups 76

By author

- $\quad$ Figure 71: Diagram of residential Option 1

By author

- Figure 72: Diagram of residential Option $2 \quad 77$

By author

- Figure 73: Diagram of residential Option $3 \quad 77$

By author

- $\quad$ Figure 74: Diagram of parks and pathways $\quad 78$

By author

- Figure 75: Perry Neighbourhood Diagram

Farr, 125.

- Figure 76: DPZ Neighbourhood Diagram

Farr, 125.

- Figure 77: Farr Neighbourhood Diagram

Farr, 126.

- Figure 78: Manor Park neighbourhoods diagram

By author

- Figure 79: Vignette of Eastbourne looking East 81

By author

- Figure 80: Aerial view showing alternate location for towers 86

By author, after Ben Gianni

- Figure 81: Alternate parti showing continuous parkland along St. Laurent Blvd 86 Randolph Wang, sketch, 2013

- Figure 82: Alternate parti showing development of a linear park storm water management along Estate St. $\quad 86$

By author, after J. Voordouw 


\section{Bibliography}

"[High Point] Photos 1 of 15." Seattle Housing Authority. http://www.seattlehousing.org/ redevelopment/high-point/photos/ (accessed June 7, 2013).

"[High Point] Redevelopment Plan." Seattle Housing Authority. http://www.seattlehousing.org/ redevelopment/high-point/plan/ (accessed June 5, 2013).

"[High Point] Replacement Housing." Seattle Housing Authority. http://www.seattlehousing. org/redevelopment/high-point/replacement/ (accessed June 5, 2013).

"[High Point] Sustainable Design." Seattle Housing Authority. http://www.seattlehousing.org/ redevelopment/high-point/sustainable/ (accessed June 5, 2013).

"Best Practices in Affordable Housing: Seattle's High Point Redevelopment Project." U.S. Department of Housing and Urban Development. http://www.huduser.org/portal/ bestpractices/study 04092012 1.html (accessed July 4, 2013).

"City of Ottawa Official Plan; 2.2 Managing Growth." City of Ottawa. http://ottawa.ca/en/ official-plan-0/22-managing-growth (accessed April 12, 2013).

"City of Ottawa Official Plan; 2.5.1 - Urban Design and Compatibility." City of Ottawa. http:// ottawa.ca/en/official-plan-0/25-building-liveable-communities (accessed April 12, 2013).

"City of Ottawa Official Plan; 5.2.2 - Stormwater Management Policies." City of Ottawa. http://ottawa.ca/en/city-hall/planning-and-development/official-and-master-plans/ infrastructure-master-plan/section-5/-1 (accessed July 12, 2013).

"City of Ottawa Official Plan; 1.4 Ottawa's Growth Management Plans." City of Ottawa. http:// ottawa.ca/en/volume-1-official-plan/14-ottawas-growth-management-plans (accessed April 12, 2013).

"City of Ottawa Zoning by-Law." City of Ottawa. http://ottawa.ca/en/residents/laws-licensesand-permits/laws/city-ottawa-zoning-law (accessed Dec. 3, 2012).

"Complete Streets for Canada; Policy and Design Hub for Building Safe and Inviting Streets for all." Toronto Center for Active Transportation. http://completestreetsforcanada.ca/whatare-complete-streets (accessed July 14, 2013).

"District Energy Warms Up Alberta's Suburbs." FCM Community Energy Planning Mission. http://www.fcm.ca/Documents/presentations/2007/mission/District energy warms up Albertas suburbs EN.pdf (accessed July 6, 2013).

"Duany Plater-Zyberk and Company; Mableton, Georgia, USA." Duany Plater-Zyberk. http:// www.dpz.com/Practice/1003 (accessed May 18, 2013).

"Duany Plater-Zyberk and Company; ARC Lifelong Communities." Duany Plater-Zyberk and Company. http://www.dpz.com/Practice/0821 (accessed May 18, 2013).

Exerpt from the Minutes of the Board of Control of the Corporation of the City of Ottawa. Ottawa: City of Ottawa, c. 1950-53.

"Former CFB Rockcliffe Lands." Canada Lands Company. http://www.clc.ca/properties/ rockcliffe (accessed July 4, 2013). 
LEED 2009 for Neighbourhood Development. Online Pdf.: Congress for the New Urbanism, Natural Resources Defense Council, The U.S. Green Building Council;, 2012.

"LEED for Neighbourhood Development." U.S. Green Building Council. https://new.usgbc.org/ leed/rating-systems/neighborhoods (accessed Nov. 6, 2012).

Manor Gardens in Manor Park Village Ottawa; Canada's most Beautiful Garden Dwellings. Ottawa, Ontario: Manor Gardens Ltd., 1950.

"Manor Park Area Present and Proposed Development Plan." In Manor Gardens in Manor Park Village Ottawa; Canada's most Beautiful Garden Dwellings. Ottawa, Ontario: Manor Gardens Ltd., 1950.

"Manor Park Community Council; Future Development." Manor Park Community Council and Manor Park Community Association. http://www.manorpark.ca/pages/neighbourhood/ development/ (accessed April 13, 2013).

"Mithun; Restoring a Community." Mithun, Inc. http://mithun.com/knowledge/article/ restoring community the high_point story/ (accessed June 5, 2013).

"Ontario's Newest Community Housing Plan." Canadian Homes \& Gardens (September, 1947): 25-32.

"Presentation Boards- Public Open House 25/05/2013; Rockcliffe Community Design Plan." Canada Lands Company. http://www.clcrockcliffe.ca/en/content/resource-library (accessed June 27, 2013).

Re. Amount Paid for Flightway Lands. Ottawa: Mayors Office, c. 1950-53.

"Slaying the Dragon of Debt; Fiscal Politics and Policies from the 1970's to the Present; 197374 Oil Crisis." The Regents of the University of California. http://bancroft.berkeley.edu/ ROHO/projects/debt/oilcrisis.html (accessed May 9, 2013).

"St. Columba Anglican Church; Parish History." http://www.stcolumbaottawa.ca/about/parishhistory/.

"Summary of Submission to Commissioner by Charlotte Whitton, C.B.E., Mayor of Ottawa." (July 7, 1953).

Township of Gloucester Minutes 1946-48, 1948.

"Transportation Master Plan; Ch. 3 Strategic Directions." City of Ottawa Strategic Planning Unit Infrastructure Services and Community Sustainability Dept. http://app06.ottawa. $\mathrm{ca} / \mathrm{cs} / \mathrm{groups} / \mathrm{content}$ @webottawa/documents/pdf/mdaw/mti2/ edisp/cap126406.pdf (accessed July 14, 2013, 2013).

Ames, David L. and Linda Flint McClelland. Historic Residential Suburbs; Guidelines for Evaluation and Documentation for the National Register of Historic Places. PDF: U.S. Department of the Interior, National Park Service, National Register of Historic Places, 2002.

Ball Scott, M. "Masters Plan for Mableton." Architecture Week; Design and Building in Depth (Aug. 29, 2012), http://www.architectureweek.com/2012/0829/index.html (accessed July 3, 2013).

Ballon, Hilary. "Robert Moses and Urban Renewal; the Title 1 Program." In Robert Moses and the Modern City; the Transformation of New York, edited by Hilary Ballon and Kenneth T. Jackson, 94. China: W.W. Norton \& Company, Inc., 2007.

Banerjee, Tridib and William C. Baer. Beyond the Neighbourhood Unit; Residential Environments and Public Policy. Environment, Development, and Public Policy., edited by Lawrence Susskind. New York: Plenum Press, 1984. 
Bloom, Nicholas Dagen. Suburban Alchemy; 1960s New Towns and the Transformation of the American Dream. Urban Life and Urban Landscapes Series. Columbus, Ohio: Ohio State University Press, 2001.

Carver, Humphrey. Cities in the Suburbs University of Toronto Press, 1965.

-- - Houses for Canadians; A Study of Housing Problems in the Toronto Area University of Toronto Press, 1948.

Cisneros, Henry G. and Lora Engdahl, eds. From Despair to Hope: Hope VI and the New Promise of Public Housing in America's Cities. Washington, D.C.: Brookings Institution Press, 2009.

Cook, Maria. "Former Airbase Redevelopment must Address Roads and Traffic." Ottawa Citizen, Nov. 26, 2012.

Duany Plater-Zyberk. Mableton, Cobb County.

Dunham-Jones, Ellen and June Williamson. Retrofitting Suburbia; Urban Design Solutions for Redesigning Suburbs. Hoboken, New Jersey: John Wiley \& Sons, Inc., 2009.

Eichler, Ned. The Merchant Builders. Cambridge, Massachusetts: The MIT Press, 1982.

Emmett, Barbara. Housing in Ottawa 1826-1980. Ottawa: City of Ottawa Non-Profit Housing Corp., Year Pub?.

Farr, Douglas. "Sustainable Neighbourhoods." In Sustainable Urbanism; Urban Design with Nature. Hoboken, New Jersey: John Wiley \& Sons, Inc, 2008.

Ferguson, Abner. Successful Subdivisions; Planned as Neighbourhoods for Profitable Investment and Appeal to Home Owners. Land Planning Bulletin no. 1., edited by Federal Housing Administration. Washington, D.C.: U.S. Government Printing Office, 1941.

Fishman, Robert. Urban Utopias in the Twentieth Century. New York: Basic Books, In., Publishers, 1977.

Flint, Anthony. "Foreward." In Suburban Transformations, 9. New York: Princeton Architectural Press, 2007.

Friedman, Avi. The Grow Home. Montreal \& Kingston: McGill-Queen's University Press, 2001.

Gottdiener, Mark. Planned Sprawl; Private and Public Interests in Suburbia. Sage Library of Social Research. Vol. 38. Beverly Hills, USA: Sage Publications Inc., 1977.

Hall, Peter. Cities of Tomorrow. Third Edition ed. Oxford, UK: Blackwell Publishing, 2002.

Jackson, Kenneth T. Crabgrass Frontier; the Suburbanization of the United States. New York: Oxford University Press, 1985.

Jacobs, Jane. The Death and Life of Great American Cities. Vintage Books Edition ed. Vintage Books, a Division of Random House, Inc., New York, 1992.

Kelly, Barbara M. Expanding the American Dream; Building and Rebuilding Levittown. Albany, N.Y.: State University of New York Press, 1993.

Kunstler, James Howard. "The Geography of Nowhere." In . New York: Simon and Schuster, 1996.

Lishman, Judy. "The Tale of Manor Park Village; the 1950s." From the March, 1988 Manor Park Chronicle. http://www.manorpark.ca/printer/neighbourhood/history/1950/ (accessed March 20, 2013).

Lukez, Paul. Suburban Transformations. New York: Princeton Architectural Press, 2007. 
Marshal-Baker, Anna and Lisa Tucker. Cradle to Cradle Home Design; Process and Experience Fairchild Books, New York, 2012.

McAffee, Ann. "Housing and Housing Policy." The Canadian Encyclopedia (2012), http://www. thecanadianencyclopedia.com/articles/housing-and-housing-policy (accessed March 20, 2013).

Mondoux, Linda. "Canada Lands Corporation Aims to Transform Rockcliffe base into Ottawa's must-have Address for Sustainable Living." MyNewWaterfrontHome.Com, March, 2012.

Moule, Elizabeth. "The Charter of the New Urbanism." In The Seaside Debates; A Critique of the New Urbanism, edited by Todd W. Bressi, 21-26. New York, NY: Rizzoli International Publications, Inc., 2002.

Nagy, Thomas. Ottawa in Maps; A Brief Cartographical History of Ottawa 1825-1973. National Map Collection., edited by Public Archives Canada. Ottawa: Information Canada, 1974.

Nash, Michelle. "Plans for Former Rockcliffe Air Base Shaping Up." Ottawa West News, June 6, 2013, sec. Business directory.

Newman, Oscar. Defensible Space; Crime Prevention through Urban Design Collier Books, a Division of Macmilllan Publishing Co., Inc., New York, 1973.

Perry, Clarence. "The Neighbourhood Unit." Chap. II., In Regional Survey of New York and its Environs. Vol. VII, 34-34-43. New York: Arno Press, 1974.

Schmoke, Kurt L. "Foreward." In From Despair to Hope: Hope VI and the New Promise of Public Housing in America's Cities, edited by Henry G. Cisneros and Lora Engdahl. Washington, D.C.: Brookings Institution Press, 2009.

Sewell, John. Houses and Homes; Housing for Canadians James Lorimer \& Company, Publishers, Toronto, 1994.

--- The Shape of the City: Toronto Struggles with Modern Planning. Toronto, Canada: University of Toronto Press Incorporated, 1993.

Seymour, M. A. City of Ottawa Land Inquiry: Report of the Commissioner M.A. Seymour Esq. Q.C. Ottawa, 1953.

Steel, James. Sustainable Architecture; Principles, Paradigms, and Case Studies. New York: McGraw Hill, 1997.

Stein, Clarence S. "Radburn." Chap. 2, In Toward New Towns for America. Third ed., 37-74. Cambridge, Massachusetts: The M.I.T. Press, 1969.

Thomas, Rob. "Highrise Condo a Canadian First." Sun Media. http://www.ottawasun.com/ news/ottawa/2009/08/10/10419716.html (accessed April, 15, 2013).

Wright, Gwendolyn. Building the Dream; A Social History of Housing in America. 3rd ed. Cambridge Massachusetts; London, England: The MIT Press, 1988. 